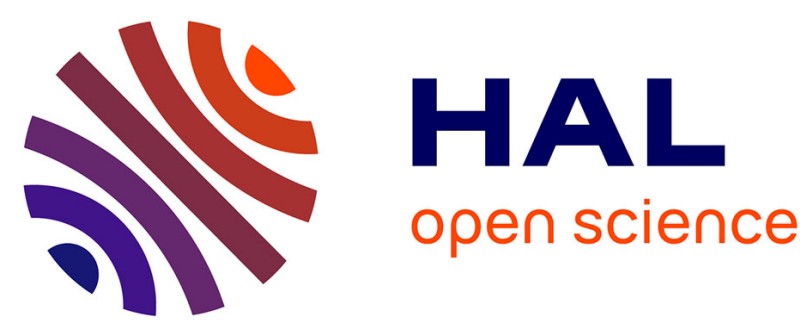

\title{
The Cenozoic volcanism in the Kivu rift: Assessment of the tectonic setting, geochemistry, and geochronology of the volcanic activity in the South-Kivu and Virunga regions
}

André Pouclet, H Bellon, K Bram

\section{To cite this version:}

André Pouclet, H Bellon, K Bram. The Cenozoic volcanism in the Kivu rift: Assessment of the tectonic setting, geochemistry, and geochronology of the volcanic activity in the South-Kivu and Virunga regions. Journal of African Earth Sciences, 2016, 121, pp.219-246. 10.1016/j.jafrearsci.2016.05.026 . insu-01330382

\section{HAL Id: insu-01330382 \\ https://hal-insu.archives-ouvertes.fr/insu-01330382}

Submitted on 11 Jun 2016

HAL is a multi-disciplinary open access archive for the deposit and dissemination of scientific research documents, whether they are published or not. The documents may come from teaching and research institutions in France or abroad, or from public or private research centers.
L'archive ouverte pluridisciplinaire HAL, est destinée au dépôt et à la diffusion de documents scientifiques de niveau recherche, publiés ou non, émanant des établissements d'enseignement et de recherche français ou étrangers, des laboratoires publics ou privés. 


\section{Accepted Manuscript}

The Cenozoic volcanism in the Kivu rift: Assessment of the tectonic setting, geochemistry, and geochronology of the volcanic activity in the South-Kivu and Virunga regions

A. Pouclet, H. Bellon, K. Bram

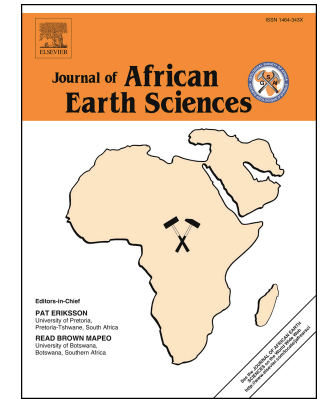

PII:

S1464-343X(16)30177-7

DOI:

10.1016/j.jafrearsci.2016.05.026

Reference: $\quad$ AES 2585

To appear in: Journal of African Earth Sciences

Received Date: 19 November 2015

Revised Date: 2 April 2016

Accepted Date: 29 May 2016

Please cite this article as: Pouclet, A., Bellon, H., Bram, K., The Cenozoic volcanism in the Kivu rift: Assessment of the tectonic setting, geochemistry, and geochronology of the volcanic activity in the South-Kivu and Virunga regions, Journal of African Earth Sciences (2016), doi: 10.1016/ j.jafrearsci.2016.05.026.

This is a PDF file of an unedited manuscript that has been accepted for publication. As a service to our customers we are providing this early version of the manuscript. The manuscript will undergo copyediting, typesetting, and review of the resulting proof before it is published in its final form. Please note that during the production process errors may be discovered which could affect the content, and all legal disclaimers that apply to the journal pertain. 


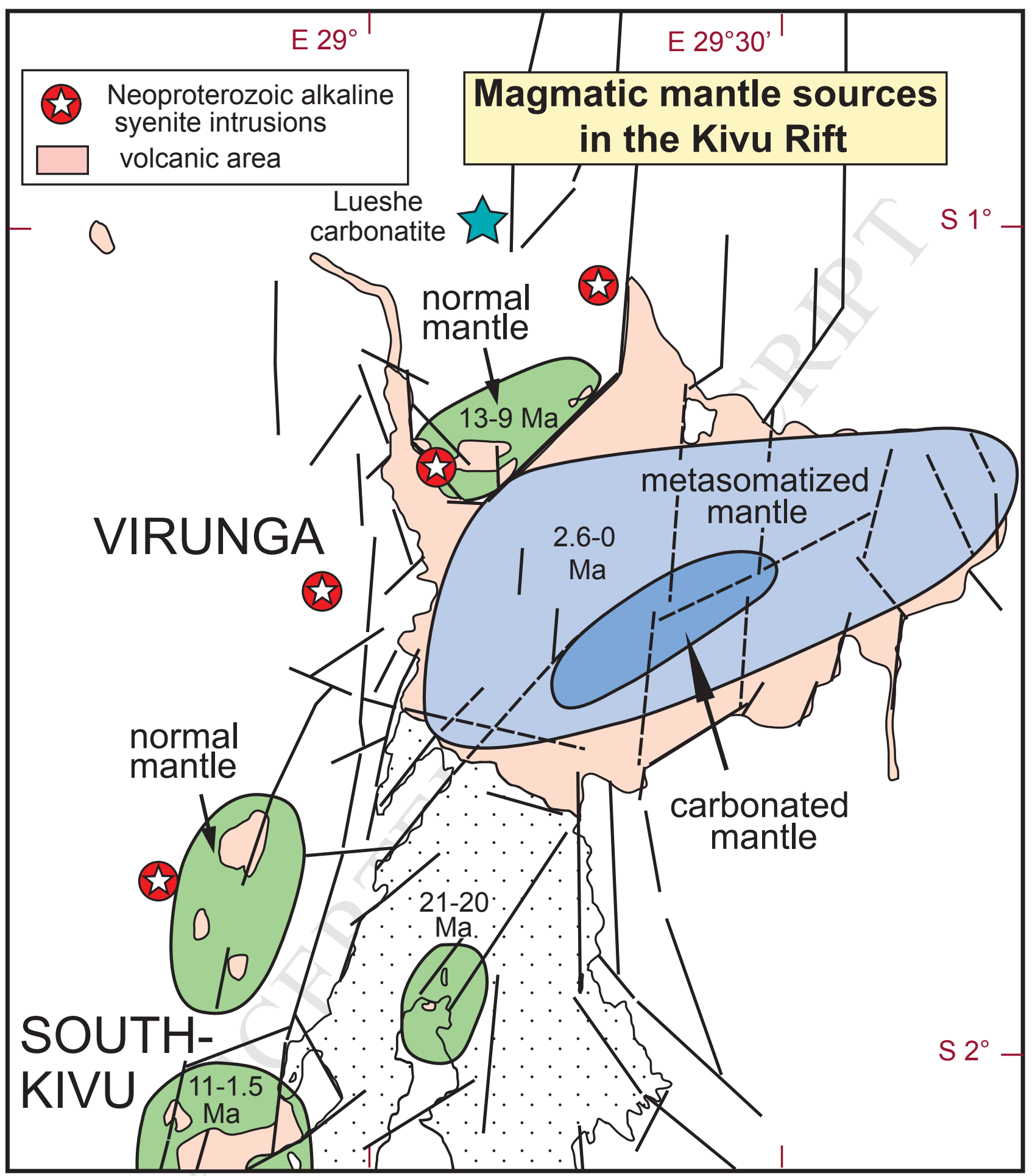




\section{The Cenozoic volcanism in the Kivu rift: Assessment of the tectonic setting,} geochemistry, and geochronology of the volcanic activity in the South-Kivu and Virunga regions.

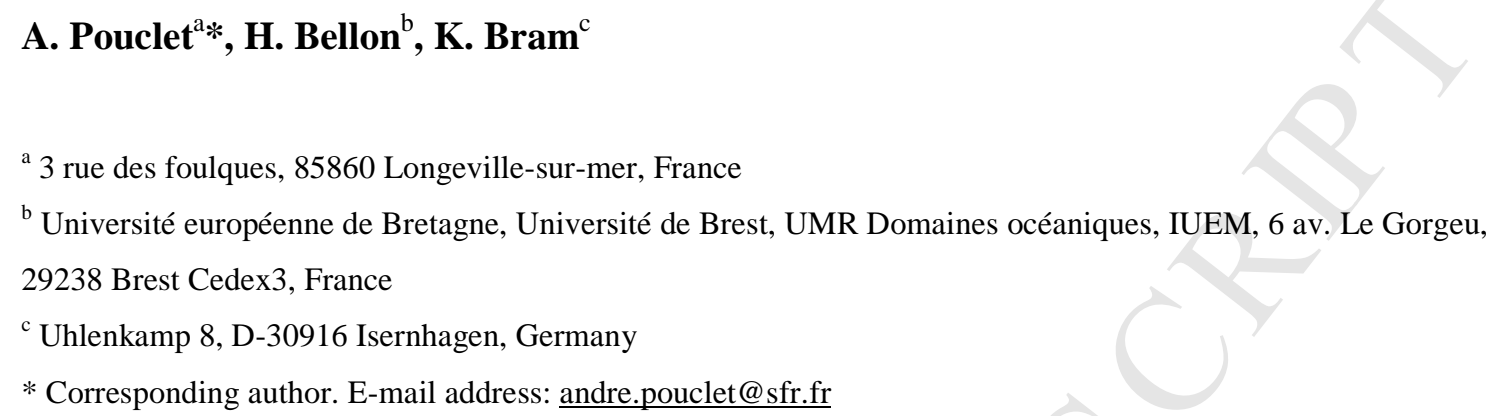

Key words: East African Rift, Kivu, Virunga, tholeiitic, alkaline and potassic lavas, K-Ar age dating

\section{ABSTRACT}

The Kivu rift is part of the western branch of the East African Rift system. From Lake Tanganyika to Lake Albert, the Kivu rift is set in a succession of Precambrian zones of weakness trending NW-SE, NNE-SSW and NE-SW. At the NW to NNE turn of the rift direction in the Lake Kivu area, the inherited faults are crosscut by newly born N-S fractures which developed during the late Cenozoic rifting and controlled the volcanic activity. From Lake Kivu to Lake Edward, the N-S faults show a right-lateral en echelon pattern. Development of tension gashes in the Virunga area indicates a clockwise rotation of the constraint linked to dextral oblique motion of crustal blocks. The extensional direction was W-E in the Mio-Pliocene and ENE-WSW in the Pleistocene to present time.

The volcanic rocks are assigned to three groups: (1) tholeiites and sodic alkali basalts in the South-Kivu, (2) sodic basalts and nephelinites in the northern Lake Kivu and western Virunga, and (3) potassic basanites and potassic nephelinites in the Virunga area. South-Kivu magmas were generated by melting of spinel+garnet lherzolite from two sources: an enriched lithospheric source and a less enriched mixed lithospheric and asthenospheric source. The latter source was implied in the genesis of the tholeiitic lavas at the beginning of the SouthKivu tectono-volcanic activity, in relationships with asthenosphere upwelling. The ensuing outpouring of alkaline basaltic lavas from the lithospheric source attests for the abortion of the 
asthenorpheric contribution and a change of the rifting process. The sodic nephelinites of the northern Lake Kivu originated from low partial melting of garnet peridotite of the subcontinental mantle due to pressure release during swell initiation. The Virunga potassic magmas resulted from the melting of garnet peridotite with an increasing degree of melting from nephelinite to basanite. They originated from a lithospheric source enriched in both $\mathrm{K}$ and $\mathrm{Rb}$, suggesting the presence of phlogopite and the local existence of a metasomatized mantle. A carbonatite contribution is evidenced in the Nyiragongo lavas.

New K-Ar ages date around 21 Ma the earliest volcanic activity made of nephelinites. A sodic alkaline volcanism took place between 13 and 9 Ma at the western side of the Virunga during the doming stage of the rift and before the formation of the rift valley. In the SouthKivu area, the first lavas were tholeiitic and dated at $11 \mathrm{Ma}$. The rift valley subsidence began around 8 to $7 \mathrm{Ma}$. The tholeiitic lavas were progressively replaced by alkali basaltic lavas until to 2.6 Ma. Renewal of the basaltic volcanism happened at ca. 1.7 Ma on a western step of the rift. In the Virunga area, the potassic volcanism appeared ca. 2.6 Ma along a NE-SW fault zone and then migrated both to the east and west, in jumping to oblique tension gashes.

The uncommon magmatic evolution and the high diversity of volcanic rocks of the Kivu rift are explained by varying transtensional constraints during the rift history.

\section{Introduction}

The Kivu Rift is the middle part of the western branch of the East African Rift system (Fig. 1). This branch separated from the main rift to the north of Lake Malawi and outlined a westward curved path from Lake Rukwa to Lake Albert. The rift valley is discontinuous in displaying a succession of deep lacustrine basins and structural heights commonly overlain by volcanic rocks, i. e. from south to north: Rungwe volcanic area, Rukwa and Tanganiyka basins, South-Kivu volcanic area, Kivu basin, Virunga volcanic area, Edward basin, ToroAnkole volcanic area, and Albert basin.

The East African rift system is commonly explained as the result of one or two mantle plumes beneath Afar and Kenyan Plateaux (Ebinger and Sleep, 1998; Rogers et al., 2000; Furman et al., 2006). It is assumed that the plateaux are dynamically supported by convective activity in the underlying asthenosphere (Ebinger et al., 1989), providing heat transfer for partial melting of the sub-continental lithospheric mantle. Numerous chemically distinctive, but dominately alkaline sodic volcanic provinces emplaced along the entire length of extensional fracture systems across the Ethyopian and Kenyan domes. In return, the western 
wranch displays limited and localized volcanic products with a great diversity of chemical compositions including potassic lavas which are rare in the eastern branch. Moreover, the time and space distribution of these various lavas, from oversaturated to undersaturated, sodic to potassic and per-potassic, is problematical and hardly understandable. No "conventional" timing of the magmato-tectonic evolution of the rift can be evidenced. Which kind of rift may provide such a diversity of magmatic rocks with unclear time-related setting? What happened in the western branch of the East African Rift system?

To document this question, it is necessary to constrain the volcano-tectonic evolution, to comfort the geochemical data, and to obtain numerous age markers. Many years ago, we sampled and studied all the volcanic rocks of the South-Kivu and Virunga areas (Pouclet, 1973, 1976, 1980; Pouclet et al., 1981, 1983, 1984; Marcelot et al., 1989). We provided the first significant age data set and discovered the North Idjwi nephelinites, the oldest lavas of the rift (Bellon and Pouclet, 1980). Since that time, a lot of papers were published, some of them providing new and accurate geochemical data (references therein in section 3).

In this study, we expose an updated synthesis of the volcano-tectonic features of the Kivu rift on the base of unpublished maps of the Kivu Lake area, Kahuzi horst, Tshibinda Volcanic Chain, Virunga area, and West-Virunga area (Figs. 2 to 6). We complete the analytical data set if necessary for some badly known volcanic series (Table. 1) and investigate the magmatological characteristics of the various volcanic series on the base of a revised nomenclature. We perform seventeen new K/Ar age measurements (Table 2) and improve the geodynamical history of the Kivu rift. We discuss about the varying behaviour of the rift tectonic constraints, the subsequent conditions of magma genesis from heterogenous mantle sources, and the role of carbonate metasomatism.

\section{Volcano-tectonic features of the Kivu Rift}

\subsection{Background}

The Kivu Rift is linked with a large lithospheric swell centred in the Lake Kivu region. It encompasses two volcanic areas: the South-Kivu area to the south, around the city of Bukavu, and the Virunga area to the north, close to the city of Goma (Fig. 1). The main structural features consist of interplayed two fault patterns: a NW-SE trending fault set and a NE-SW to NNE-SSW trending fault set. Some of these faults are reworked fractures of the Precambrian crust which played as normal faults when a large uplift event affected the eastern Congo. The 
103 NW-SE faults control the rift section from Lake Rukwa to north of Lake Tanganyika. They

104 are inherited from Palaeoproterozoic Rusizian and Ubendian structural patterns. Clearly, the

105 rift extends along the Ubendian Belt, a prominent NW-SE crustal structural weakness

106 between the Archaean Bangweulu Block and the Tanzania Craton (Boven et al., 1999; Tack et

107 al., 2010). The NE-SW faults dominate the Lake Kivu region. They belong to the

108 Mesoproterozoic Karagwe-Ankole Belt and are overprinted, to the west of Lake Kivu, by

109 NNE-SSW faults of the Neoproterozoic Itombwe Synclinorium which reoriented the rift

110 direction (Villeneuve, 1987: Villeneuve and Chorowicz, 2004). At the NW to NNE turn of rift

111 direction, from Tanganyika to Kivu lakes, the two fault sets are crosscut by newly born N-S

112 fractures constituting a third set, which developed during late stage of the rift tectonic process.

113 The rift is asymmetric. The western edge is larger and higher than the eastern edge, and east-

114 facing faults are more abundant than the west-facing ones. Similar half-graben structure is

115 described in the Tanganyika rift and explained by the flexural cantilever model (Kusznir and

116 Ziegler, 1992), implying isostatic response of the lithosphere to a continental extension by

117 planar faulting in the upper crust. The E-W crustal extension is estimated to be less than 16

$118 \mathrm{~km}$ (Ebinger,1989a, b). The offset of the rift axis between the Tanganyika and Kivu lakes is

119 accommodated by oblique-slip transfer faults along the Rusizi valley. Besides, we explain the

120 southwestern segment of Mwenga by a southwestward propagation of the rift, based on age

121 dating of the basaltic lavas (see geochronological section).

122 The South-Kivu volcanic area is centred at the crossing of the NW-SE and NNE-SSW fault

123 sets in a classical accommodation zone (Ebinger et al., 1999). It consists of abundant lava

124 flows of olivine tholeiites and sodic alkali basalts, and of few trachy-phonolitic extrusions, all

125 being dated from late Miocene to Pleistocene. The Virunga volcanic area is located at a

126 WSW-ENE dextral shift of the rift, and also in an accommodation zone. It consists of eight

127 large strato- and shield-volcanoes, Nyamuragira (3,058 m), Nyiragongo (3,470 m), Mikeno

128 (4,437 m), Karisimbi (4,507 m), Visoke (3,711 m), Sabinyo (3,634 m), Gahinga (3,500 m),

129 and Muhavura (4,127 m), from south-west to north-east. Mikeno and Sabinyo are the oldest

130 volcanoes and are dated, respectively, to late Pliocene and to Early Pleistocene. Nyiragongo

131 and Nyamuragira are presently active. The other volcanoes were active from Middle

132 Pleistocene to recent time. Two different magmatic suites are displayed: leucite-bearing

133 basanites and evolved lavas at Nyamuragira, Karisimbi, Visoke (pro parte), Sabinyo, Gahinga

134 and Muhavura, and leucite-melilite nephelinites and nepheline-leucitites at Nyiragongo,

135 Mikeno and Visoke (pro parte) (Pouclet et al., 1981, 1983, 1984). In addition, remnants of

136 basaltic lava flows, dated to Miocene, are preserved at the upper western edge of the rift. They 
137 predated the major fault motion of the rift shoulder and the building of the great volcanoes of 138 the main Virunga area (Pouclet, 1975, 1977).

\subsection{Main features of the Lake Kivu and South-Kivu volcanic area}

141

\subsubsection{Tectonic pattern}

The tectonic evolution of the Kivu rift is witnessed by the Lake Kivu structural and sedimentological features. Dating the sedimentary deposition pattern is the best way for defining the tectonic events. Oscillations of the water level are related to climatic phases but also to tectonic pulses and lava damming of outlets. For these reasons, we draw the tectonic map of the Lake Kivu of the Figure 2, after the bathymetric map and the geophysical data of Degens et al. (1973) and Wong and Von Herzen (1974). The Kahuzi Mountain is another key sector for timing the doming of the rift and the subsidence of the rift valley, because it is the source of the Lugulu flows, a large lava pile running down to the west (Fig. 1). For that reason, a field work was done and we draw a sketch map of the volcanic source area in the

Figure 3. The youngest volcano-tectonic activity took place in a western upper step of the rift, east of the Kahuzi horst and built a chain of strombolian volcanoes. We mapped this chain in the Figure 4, in order to illustrate its tectonic relationships.

The Lake Kivu is made of a northern basin and two western and eastern basins. The northern basin is a tectonic trough including $400 \mathrm{~m}$ of lacustrine sediments. According to the sedimentation rate, the basin may be dated back to about $5 \mathrm{Ma}$ (Degens et al., 1973). The sediment substratum is at around $600 \mathrm{~m}$ of elevation. The mountainous edges reaching 3,000 $\mathrm{m}$, the relative vertical motion is calculated at 2,400 $\mathrm{m}$ (Pouclet, 1975). The western and eastern basins, on both sides of the Idjwi Island, were former valleys, with rivers flowing down to the northern basin. These valleys were flooded after the damming of the lake northern run-off, which resulted from building of the Nyiragongo and Nyamuragira volcanoes, in the late Pleistocene. The maximum water level reached 1,650 m, at the Bukavu shelf level, ca. 10,000 years ago (Denaeyer, 1954; Pouclet, 1975, 1978). Then, it lowered in furthering the excavation of the Rusizi canyon. The Lake Kivu southward overflow is recorded in the Lake Tanganyika sediments at 9,400 yr BP (Haberyan and Hecky, 1987) or 10,600 yr BP (Felton et al., 2007). The early Holocene high water level coincided with the formation of sub-lacustrine flank volcanoes in the Virunga area, at the northern shore of the lake. But this high level cannot explain the formation of the under-water hyaloclastite vents of South-Idjwi which are much older and thus related to a previous lacustrine basin (Pouclet, 
171 1975, 1978). The present-day level of $1,462 \mathrm{~m}$ is stabilized by the hydroelectric dam of 172 Bukavu.

173 The deep northern basin is crosscut by SW-NE tectonic steps (cross-section A-B, Fig. 2).

174 The southern part consists of an alternation of horsts and basins trending SSW-NNE (cross175 section C-D). All the fractures play as normal faults with horst uplifting, graben sinking, and 176 tilting of the steps. The western edge culminates at Mount Kahuzi (3,308 m), which is a

177 Neoproterozoic intrusive complex of acmite- riebeckite-bearing granite, syenite, and quartz-

178 porphyry microgranite, as well as the neighbouring Mount Biega (2,790 m) (Ledent and

179 Cahen, 1965; Kampunzu et al., 1985). These intrusions are dated between 800 and 700 Ma,

180 according to the ages of neighbouring similar alkaline intrusions in the western edge of the

181 rift (Van Overbeke et al., 1996; Kampunzu et al., 1998a).

182 The Kahuzi Mountain is the source area of important flows (Fig. 3). At its western and 183 southern feet, basaltic flows poured out in westward direction from a fracture system, in the

184 Miocene to Pliocene time. Four main lava flow units are distinguished. Doleritic facies are

185 localized along NW-SE fractures, at the southern to south-western foot of the massif,

186 indicating the feeder sites. Heating of the Kahuzi area by rising of this basaltic magma is

187 probably responsible for rejuvenation to 134 and 55 Ma of K-Ar ages of the Kahuzi rocks

188 (Bellon and Pouclet, 1980). At present, the Lugulu flows consist of a reverse topographic

189 relief of elongated hills. The lava flowed down to the west, but not to the east. They poured

190 out during the doming stage of the rift and predated the formation of the rift because they are

191 cut by the major faults of the rift scarp. Indeed, to the eastern foot of the Kahuzi heights, on

192 the Tshibinda step (Fig. 4), the Quaternary Tshibinda basaltic flows overlie metasediments of

193 the Precambrian substratum, which is devoid of any older lava cover. We thus conclude that a

194 true rift valley did not exist across the swell at the Kahuzi lava flowing time, and lavas only

195 flowed down to the western slope of the dome.

196 The rift valley initiated in the latest Miocene. East of the western higher steps, Late

197 Miocene lavas are preserved in the Kavumu lowland where they are partly overlain by the

198 Tshibinda Quaternary flows (detailed in the following section). They widely flooded to the

199 Lake Kivu and to the Bukavu and Bugarama grabens, and also poured out in the SSW

200 segment of the rift, the Mwenga graben (Figs. 1 and 2). The western basin of the Lake Kivu is

201 the continuation of the Bukavu Graben. The Idjwi Island is the northern prolongation of the

202 Mushaka horst that separated the Bukavu and Bugarama-Bitare grabens. There is not a single

203 rift valley. However, the deepest part locates in the eastern basin of the lake, where the main

204 rift axis can be assumed to be, in the continuation of the Bitare-Bugarama Graben (Fig. 1). 
Fault associated mineral hot springs are abundant (Fig. 2). Many of the faults are more or less presently active as illustrated by the Frebuary 3, 2008 earthquake along the Luhini Fault (Fig.

207

208

209

210

211

212

213

214

215

216

217

218

219

220

221

222

223

224

225

226

227

228

229

230

231

232

233

234

235

236

237

238 4).

\subsubsection{Volcanic activity}

The South-Kivu volcanic activity mainly consisted of basaltic flow piling from fissural eruptions, in the Late Miocene to Late Pliocene (10 to 2.6 Ma; Kampunzu et al., 1998b). In the Pleistocene, a renewed strombolian volcanic activity has built the chain of Tshibinda (Bellon and Pouclet, 1980) (Fig. 4). In the stacked lava field, the old volcanic vents can be localized by their feeder dykes and by interbedded pyroclastic materials, which locally gain a few metres in thickness. Occurrences of intercalated tephra are common, but well-preserved scoria cones are absent or limited to the recent Tshibinda volcanic chain. Some metre-sized basaltic dykes are present in the western (Congo side) and eastern (Rwanda side) upper steps and also in the Mwenga area. They are trending N-S to NE-SW. These features are consistent with linear basaltic eruptions along cracks fringed with small scoria cones. Trachy-phonolitic extrusions are only known in the Bukavu Graben, into and close to the upper-Rusizi canyon. They are dated from 6.14 Ma to 5.05 Ma (Pasteels et al., 1989). In this area, we number five decametre- to hectometre-sized bodies, which intruded a lower basaltic pile and are overlain by flows of olivine basalt and hawaiite.

The Pleistocene chain of Tshibinda consists of numerous well-preserved scoria cones and lava flows (Fig. 4). The chain is named after the Tshibinda site, in its southern end, where the first scoria cones were discovered (Meyer and Burette, 1957). The cones are set at the border of the Tshibinda step, at the eastern foot of the Kahuzi upper shoulder. The chain is $33 \mathrm{~km}$ long in a SSW-NNE direction, from Tshibinda to Leymera. During our mapping, we numbered sixty strombolian cones, 50- to $150 \mathrm{~m}$-high. Most of them are opened and have supplied lava flows. A few flows run to the west, in following the slope of the tilted step, but most of them came down the fault scarp and spread towards the eastern lowlands. A prominent feature is the alignment of vents along SSE-NNW fractures ( $\mathrm{N} 160^{\circ}$ trend) in the Tshibinda and Tshibati sectors. This fracture system is consistent with a NE-SW left-lateral strike slip constraint, and an ENE-WSW extensional strain. We dated the Tshibinda chain activity from 1.9 to $1.6 \mathrm{Ma}$ (Bellon and Pouclet, 1980). Younger ages have been suggested but not proved (Pasteels et al., 1989).

\subsection{Main features of the Virunga volcanic area}




\subsubsection{Tectonic pattern}

The Virunga volcanic area is located between the Kivu and Edward lakes on a structural height or shoal between two troughs (Fig. 5). The continuation of this shoal beneath the Nyiragongo and Nyamuragira volcanoes is based on sedimentological, volcanological and geophysical evidence (Pouclet, 1975). Its level averages 1,200 m, while the nearest higher topographical Mount Muhungwe rift edge reaches 2,990 m. Thus, the relative vertical motion of the rift floor is around $1,800 \mathrm{~m}$. Subsidence of the Lake Kivu bottom reached approximately $600 \mathrm{~m}$ below the shoal level.

The tectonic pattern is linked to right lateral shift of the rift axis between Kivu and Edward lakes, which is underlined by the SW-NE Tongo, Muhungwe, and Rutshuru faults. However, motion along these faults is dominantly vertical. This motion is evidenced by the uprising of sedimentary terraces at the foot of the Tongo scarp to the west, and along the

252

Rutshuru Fault to the east as shown in the Figure 6. These terraces contain Early to Middle Pleistocene littoral sediments of the Lake Edward. They recorded an uplifting of 1,000 m along the Tongo Fault, and of $500 \mathrm{~m}$ along the Rutshuru Fault (Pouclet, 1975). Taking into account a vertical motion of $500 \mathrm{~m}$ before the Early Pleistocene sediment deposition, the total vertical motion of the Tongo Fault is calculated around 1,500 $\mathrm{m}$. The south-eastern side registered a vertical motion of 1,000 $\mathrm{m}$ at the Muhungwe Fault. This motion in evidenced along the N-S Kisenyi Fault, in the continuation of eastern border of the Lake Kivu northern trough. Meanwhile, at the eastern end of the Virunga area, vertical displacements are limited to a few hundred of metres along N-S and SSE-NNW faults.

The structure and nature of the volcanic substratum are constrained by the trends of the volcano-tectonic framework and the composition of the volcanic xenoliths. In the Virunga area, underlying cliffs moulded by lavas can explain some major topographic uneven differences. It is the case for the N-S west-facing scarp between the Karisimbi-Mikeno volcanoes, in the upper eastern side, and the Nyiragongo-Nyamuragira volcanoes, in the lower western side. This scarp is in the continuation of Rwandese east-Kivu Fault (Fig. 1) and is connected with the eastern fault of the Kirwa sedimentary terrace (Fig. 5). It is named the "Virunga Fault". This fault has right-lateral en echelon segments, as shown by shift of the Kirwa Fault to the fault of the low Rutshuru terrace. A sub-parallel less important scarp separates the Mikeno to the Karisimbi-Visoke, and is linked to a fault at the north-western border of the Precambtian substratum, south of the Rutshuru Fault. It is named the "Mikeno Fault". A third scarp is located between Sabinyo and Gahinga. To the lower southern flank of 
273 Nyiragongo, a transverse WNW-ESE scarp is merely related to a fault between the Virunga 274 shelf and the northern basin of Lake Kivu.

275 Two types of volcanic fractures are distinguished. Some fractures show radial distribution 276 on the flank of the largest volcanoes. But many others are aligned independently of the 277 volcano building shape. A SW-NE trend of fractures locates in the prolongation of the east 278 fault of the M'Buzi peninsula. It reveals a major fault between Nyiragongo and Nyamuragira, 279 the "Kameronze Fault", which is ascertained for many reasons. Firstly, the M'Buzi block is 280 extended below the lava cover, according to gravimetric data (Evrard and Jones, 1963). 281 Secondly, the xenoliths of Nyiragongo consist, solely, of granite rocks, while those of 282 Nyamuragira are made of metashales, quartzites, and micaschists. Thus, the two volcanoes 283 were emplaced in two geologically different steps of the rift floor. Thirdly, there is a 284 deepening of focal depth of tectonic earthquakes from west, in the Nyamuragira area, to east, 285 in the Nyiragongo area (Tanaka, 1983). Fourthly, the Kameronze fractures have provided 286 original lava, the rushayite, an ultrabasic olivine-rich melilitite, which is unknown in the rest 287 of Virunga. This rare lava could be originated from a deep cumulate zone of the Nyiragongo 288 magma chamber or from an independent reservoir (see discussion in section 3.4.). Thus, the 289 Kameronze Fault separates the low granitic step of Nyiragongo to the upper meta-sedimentary 290 step of Nyamuragira. The two neighbouring volcanoes have very different lava compositions. 291 Their different setting in two distinct crust compartments may explain their different way of 292 magma feeding. A SSW-NNE fracture set is partly in the continuation of the Kameronze 293 Fault to the north-east. But, its related eruptive vents produced Nyamuragira-type lavas. An 294 important SW-NE fissural complex is located between Visoke and Sabinyo. In the same 295 direction, main fractures crosscut the Mikeno, Visoke, and Sabinyo edifices. This complex is 296 linked to a SW-NE major fault emplaced between the Mikeno NW-base and the Karisimbi297 Visoke step, parallel to the Muhungwe Fault of the rift edge.

298 Undeniably, the most important present-day fracture system is the great NNW-SSE 299 fracture zone or weakness zone of Nyamuragira that crosscuts the caldera and the shield 300 volcano, reaching $20 \mathrm{~km}$ in length (Pouclet and Villeneuve, 1972; Pouclet, 1976, 1977). In 301 many parts, this tectonic zone is a trench, 15 to $30 \mathrm{~m}$ wide and 20 to $30 \mathrm{~m}$ deep, limited by 302 two parallel sub-vertical fractures. It is associated with slightly parallel secondary fissures, on 303 the NNW and SSE upper flanks. It extended from Nyamuragira to the Nyiragongo area, 304 across the Kameronze Fault, with large fissures at the NNW flank of this Nyiragongo. This 305 tectonic system, having an axial direction of $\mathrm{N} 155^{\circ}$, can be considered as a mega tension 
306

307

308

309

310

311

312

313

314

315

316

317

318

319

320

321

322

323

324

325

326

327

328

329

330

331

332

333

334

335

336

337

338

gash. In the NNW flank of the Nyamuragira caldera, there is a spectacular fan-shaped succession of fissures where thirteen eruptive events took place since the year 1900.

In addition, the Nyamuragira shield is crossed by N-S faults. In the northern wall of the caldera, a N-S fault shows a two metres-displacement of the lava pile and is intruded by a dyke. The fault motion has occurred after the setting up of the initial summit cone, but before the caldera collapse (Pouclet, 1976). In the SW upper flank, a N-S fault was active during the 1938 eruption that drained a large volume of lava from the caldera. The western flank of the shield displays a morphological lowering of 30 to $40 \mathrm{~m}$. A less important lowering of the SSE flank is due to a N-S fault associated with the Kameronze Fault. Important N-S fractures also concern the southern flank of Nyiragongo. They were responsible for draining of the caldera lavas during the dramatic 1977 and 2002 eruptions (Pottier, 1978; Komorowski et al., 2002). It is concluded that the N-S fractures, not only controlled the structural pattern of the Virunga substratum (Virunga and Mikeno faults), but also play a present-day important role in the tectonic constraints triggering volcanic eruptions.

\subsubsection{Volcanic activity}

The Volcanic activity began in the Late Miocene. The oldest lavas are preserved as residual basaltic flows, above the western edge of the Bishusha-Tongo area as depicted in Figure 6. They are dated between 12.6 and 8.6 Ma (Bellon and Pouclet, 1980; Kampunzu et al., 1998b). They predated the $1,500 \mathrm{~m}$ vertical motion of the Tongo fault system, and then, the rifting process and the main volcanic activity of the Virunga area (Pouclet, 1977). For these lavas we use the term "pre-Virunga" magmatic activity because there is an important time gap and a drastic difference of composition between these Miocene lavas and the Quaternary Virunga lavas. We numbered and sampled a dozen of scattered outcrops of basaltic rocks at small hills in the Bishusha area, above and along the Mushebele scarp, and above the Tongo scarp (Fig. 6). They belong to different dissected and highly eroded lava flows, as it is attested by the various petrographical compositions (olivine basalt, basanite, hawaiite, mugearite, benmoreite) and frequent doleritic textures of the mafic rocks. The lava setting is controlled by NW-SE and NNW-SSE fractures, the same directions that were used by the two recent Mushari fractures of satellite eruptions of Nyamuragira. No field relationships between the flows, in term of succession order, can be inferred. In addition, a thick blanket of tephra coming from the numerous Nyamuragira flank eruptions overlies the entire area. 
At the middle flank of Mount Mushebele, an olivine basalt lava flow seems to be overlain by a hawaiite flow that crops out at the top of the scarp. However, the hawaiite is dated at 12.6 \pm 0.7 Ma (Bellon and Pouclet, 1980) and the basalt at 10.8 $\pm 1.7 \mathrm{Ma}$ (Kampunzu et al., 1998b). The 12.6 Ma age was questioned because the hawaiite being at a higher altitude than the basalt must be younger (Kampunzu et al., 1983). There is an alternative explanation: The two lavas are separated by an important normal fault and the hawaiite was tectonically displaced above the basalt.

The other lavas of the west Virunga area are the Mweso valley flows and the Pinga flows (Fig. 1). The Mweso flows poured out in the Mokoto Bay. Their source is hidden by the recent flows of Nyamuragira (Fig. 6). The lavas extended along $32 \mathrm{~km}$ in the valley, from Mokoto to the NNW end of the flow system. Our sampling shows that the petrographical composition remains constant: olivine basalt with microphenocrysts of skeletal olivine and aggregated phenocrysts of diopside and labradorite. At the Pinga area, residual basaltic flows are pointed out in the Pinga village and $35 \mathrm{~km}$ west of this village, in the Oso valley, (De La Vallée-Poussin, 1933). These lavas cannot belong to the Mweso flow, for topographical evidences, but recalls the Numbi lava for their western position out of the rift. More accurate studies are needed for precising their petrographical and chemical compositions.

The volcanic activity of the Virunga main area began with Mikeno, in the middle part of the shelf between the Kivu and Edward troughs. This volcano was active around 2.6 Ma and maybe until 0.3 or $0.2 \mathrm{Ma}$ (Guibert et al., 1975). The old age of Sabinyo, the second oldest volcano, is only attested by its erosional feature similar to that of Mikeno. Its base is totally covered by lavas from Gahinga and Visoke. It was active around 0.1 Ma (Bagdasaryan et al., 1973; Rançon and Demange, 1983; Brousse et al., 1983; Rogers et al., 1998). Thus, the erosion of Sabinyo may be recent and due to violent volcano-tectonic activities. Gahinga and Muhavura are dated between 0.29 and 0.03 Ma (Rançon and Demange, 1983; Rogers et al., 1998), but recent activities are suspected (Brousse et al., 1983). Visoke consists of two superposed stratovolcanoes (Ongendangenda, 1992). The upper one is as old as 0.08 Ma (Bagdasaryan et al., 1973). Its last eruption in 1957 produced the adventive cone of Mugogo on the lower north flank (Verhaeghe, 1958). Karisimbi is made of a shield volcano overlain by two successive upper flank large cones (De Mulder, 1985). It is dated between 0.14 and

370 Nyamuragira emplaced since $12 \mathrm{ka}$ on the lower steps of the Virunga shelf (Pouclet, 1978).

371 Nyiragongo is a combination of three stratovolcanoes, from south to north: Shaheru, 
372 Nyiragongo main cone and Baruta. Shaheru, the first volcano of the complex, may be as old 373 as 0.1 Ma (Demant et al., 1994).

374

375

\section{Geochemical composition of lavas}

376

377

Numerous geochemical analyses of South-Kivu and Virunga lavas are available from the

378

379

380

381

382

383

384

385

386

387

388

389

390

391

392

393

394

395

396

397

398

399

400

401

402

403

404

405

literature, though their accuracy is highly variable. Trace element and isotopic data are provided by Mitchell and Bell (1976), Vollmer and Norry (1983), Hertogen et al. (1985), Vollmer et al. (1985), De Mulder et al. (1986), Auchapt (1987), Auchapt et al. (1987), Marcelot et al. (1989), Toscani et al. (1990), Demant et al. (1994), Rogers et al. (1998), Furman and Graham (1999), Platz et al. (2004) and Chakrabarti et al (2009a). These data are reviewed and, when necessary, completed by new analyses (Table 1). The analytical set is used to discuss the petrological features and the magmato-tectonic relationships dealing with the rift formation and evolution. South-Kivu basalts derived from a heterogeneous lithosphere mantle source by variable degrees of melting (Auchapt et al. 1987; Furman and Graham, 1999). Both the leucite-basanite and leucite-nephelinite series of Virunga resulted from moderate or small amount of partial melting of mica-garnet-lherzolite lithospheric and/or asthenospheric mantle, with contribution of carbonatite for the more alkaline series (Pouclet, 1973; Furman and Graham, 1999; Chakrabarti et al., 2009a).

In the South-Kivu and Virunga area, it has been shown in the section 2 that volcanism and doming preceded the rifting, with the Kahuzi and pre-Virunga basalts. Asthenospheric upwelling caused uplift of the lithosphere and partial melting of various sources. However, to document that model, we have to clarify some intriguing questions, because the geochemical data from literature are, in many cases, incomplete and not representative, and sometimes inexact. The questions concern the early and late activity of South-Kivu, the poorly known volcanism of North-Idjwi between South-Kivu and Virunga, and the early activity of Virunga.

What is the composition of the earliest volcanic rocks in South-Kivu? Is it really tholeiitic? It is necessary to ascertain the existence, the age, and the tectonic location of true tholeiites, in one hand, and the timing of the rift formation, in the other hand. The Quaternary South-Kivu Tshibinda volcanoes erupted simultaneously with some Virunga volcanoes. Their basaltic composition is close to that of South-Kivu lavas. What is their place in the South-Kivu magmatic evolution? The early Miocene North-Idjwi lavas are the oldest dated lavas of the Kivu rift. They are not tholeiites but nephelinites. What is their magmato-tectonic meaning between the South-Kivu and Virunga areas? The Miocene pre-Virunga lavas predated the rift 
406 formation, and may be contemporaneous with the first South-Kivu activities. They are very

407 different from the Quaternary Virunga lavas. Their composition, tholeiitic to alkaline, is a

408 matter of debate. What is the true composition of the pre-Virunga lavas? Is it similar to that of

409 the South-Kivu? And, finally, what is the origin of the original features of the Virunga lavas?

410

\section{3.1. South-Kivu lavas}

412

413 South-Kivu lavas mainly consist of alkali basalts and tholeiites. The first question deals

414 with the true composition of tholeiites and their meaning in the rift evolution. Then, we revise

415 the composition and the nomenclature of the various volcanic rocks. Most of the activities are

416 dated in the Miocene and Pliocene, but a renewal occurred during the Pleistocene in the

417 Tshibinda site. New analytical data are provided for to better constrain this last magmatic

418 event.

419

420

\subsubsection{The tholeiite question}

421

Tholeiite lavas have been pointed out at different parts of the South-Kivu volcanic area and in the pre-Virunga field, with various ages. They are very important in the debate about the tectono-magmatic history of the rift. But, examination of these lavas is problematic. Many "tholeiites" have been defined on the basis of their major element composition (low abundance of alkali elements), without mineralogical arguments. As they are always more or less altered, in having high loss on ignition, they could be former alkali basalts secondary depleted in alkali elements. It is tritely verified that altered olivine-rich basalt may display oversaturated norm composition. In addition, it is ascertain for tholeiites by Pasteels and Boven (1989) that many K-Ar ages are questionable, due to alteration (loss of K and/or Ar) and to magmatic argon excess. This tholeiite problem leads to three questions: 1) Are there true tholeiites? 2) Is there a space distribution of tholeiites from the border to the rift axis? 3) Is there a time relationship in the tholeiite and alkali basalt production?

The criteria for defining true tholeiites are their mineral content, crystallization order, and major and trace element composition. Early olivine phenocrysts are absent. Calcic plagioclase crystallizes before sub-calcic pyroxene. For that reason, the tholeiitic doleritic facies displays intersertal texture. Olivine only exists as residual and corroded xenocrysts. There is a single pyroxene of sub-calcic augite composition, or two coexisting pyroxenes that are augite and 
$10 \%$ hypersthene. Trace element pattern of continental tholeiites exhibits moderate

441

442

443

444

445

446

447

448

449

450

451

452

453

454

455

456

457

458

459

460

461

462

463

464

465

466

467

468

469

470

471

472

473

enrichment of the most incompatible elements. However, olivine-tholeiites contain

microphenocrysts of ferrous olivine and partly syncrystallizing plagioclase and augite leading to intergranular or sub-ophitic textures in doleritic facies. Their norm composition is saturated with variable amount of hypersthene. The most incompatible elements are slightly more enriched than for tholeiites.

On the basis of these mineralogical and geochemical criteria, examination of the South-

Kivu lavas indicates that true tholeiites are present at five sites: West-Kahuzi, South-Idjwi and Mushaka horst, Bitare-Buragama graben, lower-Rusizi (southern continuation of the Bugarama graben), and Mwenga. Olivine-tholeiites are present at the same sites, plus the Bukavu graben. The answer to the question of space and time distribution is more complicated. Tholeiites are localized along the rift axis, but also at distant fields, though they are concentrated close to the rift axis. Concerning the chronological setting of tholeiites versus alkali basalts, tholeiites are everywhere overlain by alkali basalts, but the transition is diachronic. For instance, at the Mwenga site, tholeiites are younger than the alkali basalts of Bukavu. On the whole, tholeiites predated alkali basalts, and, for that reason, they crop out in the most eroded topographical landscapes. Because the erosion process is variable, the distribution of tholeiites is not known for all the volcanic area.

\subsubsection{Composition of lavas}

To display relative abundances and features of tholeiitic rocks compared with alkaline lavas, a set of representative and accurate chemical analyses is provided in Table 1. Poorly described and altered lavas are eliminated. Thanks to this precaution, we adopt a normative classification slightly modified from Green (1969): 1) quartz-bearing and hypersthene-rich tholeiite, 2) olivine-tholeiite containing olivine and more than $15 \%$ hypersthene, 3 ) olivine basalt containing olivine and less than $15 \%$ hypersthene, 4 ) alkaline-basalt with 0 to $5 \%$ nepheline, 5) basanite with 5 to $15 \%$ nepheline, and 6) nephelinite having more than $15 \%$ nepheline. Classification of the South-Kivu, North-Idjwi, and Pre-Virunga lavas is accomplished using a tetrahedral diagram of normative proportions of Qtz, Hy, Ol, $\mathrm{Ne}+\mathrm{Le}$, and Ab+Or (Fig. 7). Compared with the tetrahedral diagram of Yoder and Tilley (1962), diopside is replaced by albite + orthose because the alkali amount is more significant than the calcium content, and the alkali abundance cannot be shown only by feldspathoids. True tholeiites plot in the $\mathrm{Qtz}-\mathrm{Hy}-\mathrm{Ab}+\mathrm{Or}$ triangle. In the $\mathrm{Ol}-\mathrm{Hy}-\mathrm{Ab}+\mathrm{Or}$ triangle, olivine- 
474 tholeiites are discriminated to olivine basalts by Hy normative amount of more than $15 \%$. In 475 the $\mathrm{Ol}-\mathrm{Ne}-\mathrm{Ab}+\mathrm{Or}$ triangle, the alkali basalt - basanite and basanite - nephelinite limits are 476 determined by Ne normative amounts of 5\% and 15\%, respectively. In this triangle, some 477 basanites of the Mwenga site are characterized by high $\mathrm{MgO}$ contents (9-12 wt \%). They are 478 rich in olivine, although being not cumulative. Then they are termed "Mg-basanites".

479 Trace element data of the new analyses (Table 1) are completed by those of Auchapt 480 (1987), Auchapt et al. (1987), Marcelot et al. (1989), and Furman and Graham (1999). In the 481 Primitive Mantle normalized incompatible elements diagram (Fig. 8A) tholeiites and olivine482 tholeiites are moderately fractionated in the light rare earth elements. Their $\mathrm{La} / \mathrm{Yb}$ ratios range 483 from 8 to 13 and from 10 to 15, respectively. They are not enriched in $\mathrm{Ba}$ and $\mathrm{Th}$, and are 484 poor in $\mathrm{Rb}$. Similar patterns are exhibited, with increasing trace element abundances and rare 485 earth element fractionation, from tholeiites to olivine basalts $(15<\mathrm{La} / \mathrm{Yb}<30)$, alkaline-basalts $486(20<\mathrm{La} / \mathrm{Yb}<35)$, basanites $(25<\mathrm{La} / \mathrm{Yb}<40)$, and $\mathrm{Mg}$-basanites $(40<\mathrm{La} / \mathrm{Yb}<50)$. As already 487 suggested by Auchapt et al. (1987), Marcelot et al. (1989) and Furman and Graham (1999), 488 this is consistent with varying degree of partial melting of a lithospheric mantle source, which 489 decreases from tholeiites to Mg-basanites, as shown by the $\mathrm{Yb}$ vs. La/Yb diagram (Fig. 9A). 490 Auchapt (1987) has calculated the source composition from a set of tholeiitic and basanitic 491 lavas of the Mwenga area. A first source, moderately enriched, (C1, Table 3) can be assumed 492 for most of the lavas. A second less enriched source (C2, Table 3) is suitable for lavas that are 493 poor in the most incompatible elements.

494 Having tested the accuracy of the Auchapt's results, we calculated the degrees of partial 495 melting after the reverse method and the source composition C1, for all the South-Kivu mafic 496 lavas and using light rare earth elements (LREE). We obtained the following values: tholeiites 497 and olivine-tholeiites $=15$ to $7 \%$, olivine- and alkaline-basalts $=6$ to $4 \%$, basanites and $\mathrm{Mg}$ 498 basanites $=3$ to $2 \%$. However, to get consistency of partial melting degrees between large ion 499 lithophile elements (LILE) and high field strength elements (HFSE), it is necessary to 500 increase the bulk partition coefficient of heavy rare earth elements (HREE), particularly in the 501 basanite case implying the presence of garnet in the source. This assertion is supported by 502 increasing HREE depletion from alkaline-basalts to basanites characterized by increasing 503 values of $\mathrm{Tb}_{\mathrm{N}} / \mathrm{Yb}_{\mathrm{N}}$ normalized ratio from 1.78 to 2.27 locating the melting column in the 504 garnet stability field. Indeed, due to the residual garnet effect, the $\mathrm{Tb}_{\mathrm{N}} / \mathrm{Yb}_{\mathrm{N}}$ melt ratio passes 505 beyond 1.8 at the spinel-garnet transition (Furman et al., 2004; Rooney, 2010).

506 Batch melting is calculated for the enriched source $\mathrm{C} 1$ and the less enriched source C2; 507 results are shown in the $\mathrm{La} / \mathrm{Sm}$ versus $\mathrm{Sm} / \mathrm{Yb}$ diagram (Fig. 9B). Melt curves are drawn for 
508 spinel-lherzolite, garnet-lherzolite, and a 50:50 mixture of spinel- and garnet-lherzolite.

509 Modal compositions of spinel-lherzolite (olivine 53\%, OPX 27\%, CPX 17\%, spinel 3\%) and

510 garnet-lherzolite (olivine 60\%, OPX 20\%, CPX 10\%, garnet 10\%) are after Kinzler (1997)

511 and Walter (1998). Mineral/melt partition coefficients for basaltic liquids are after the

512 compilation of Rollinson (1993). Tholeiites may have resulted from ca. 10\% of partial

513 melting of spinel-lherzolite from a moderately enriched source. But, globally, South-Kivu

514 magmas may be generated by melting of spinel+garnet lherzolite, from enriched source

515 between the $\mathrm{C} 1$ and $\mathrm{C} 2$ calculated compositions, assuming increasing amount of garnet, from

516 tholeiites to basanites. Hence, melting took place in the spinel-garnet transition zone at depth

517 surrounding $80 \mathrm{~km}$. The more abundant garnet content in the basanite source locates its

518 melting in the lower part of the transition zone. Partial melting degree of the $\mathrm{C} 1$ source

519 decreases from $20 \%$ to $5 \%$, from basalts to basanites, along the 50:50 spinel+garnet-lherzolite

520 curve. Lower degrees of partial melting (8\% to 2\%) and lower amounts of garnet are

521 determined with the $\mathrm{C} 2$ source. But, the large dispersion of plots suggests compositional

522 heterogeneities and/or mixing in the melted sources.

523 Contribution of these different sources has to be tested by using all the incompatible

524 elements. However, chemical bias may be due to crustal contamination and assimilation. This

525 latter process can be evidenced in the $\mathrm{Nb} / \mathrm{Yb}$ versus $\mathrm{Th} / \mathrm{Yb}$ diagram (Fig. 10). Crustal effect is

526 suspected in the case of thorium enrichment unrelated to magmatic processes. In this diagram,

527 all the lavas plot in the Mantle array along the partial melting vector. No particular Th-

528 enrichment is visible, precluding perceptible crustal assimilation. In addition, Sr-isotopic data

529 of Furman and Graham (1999) do not display Sr anomalous pattern. Hence, the chemical

530 scatter only resulted from magmatic processes, and the analytical data, namely the

531 incompatible element values, can be used to discern magmatic patterns of the different lava

532 suites.

533 To test the behaviour of incompatible elements, bivariate diagrams have been carried out.

534 Results are illustrated in Figure 11 with three selected diagrams. La versus Yb diagram

535 shows data scatter between two partial melting curves: a low-Yb and high-La curve, and a

536 low-La curve (1 and 2, Fig. 11A). The lack of significant $\mathrm{Yb}$ increase is due to garnet effect,

537 mainly in basanites, which are the most LILE-enriched and-HREE-depleted lavas. The high-

538 La curve evolves from basanites to olivine basalts and can be related to the enriched $\mathrm{C} 1$

539 source. The low-La trend characterizes tholeiites and some olivine basalts; it may be inherited

540 from the less-enriched C2 source (3), as suggested above (Fig. 9B). Fractional crystallization

541 is limited to few tholeiites and olivine basalts (see also Fig. 10A). The Ba versus La diagram 
542 displays a high-Ba curve, a low-Ba curve and an intermediate high-Ba and high-La pattern (1,

5432 and 3, Fig. 11B). Nb versus Zr diagram shows a low-Zr curve, a high-Zr curve and an

544 intermediate trend (1, 2 and 3, Fig. 11C). It is concluded that high-Ba and low-Zr values

545 (trend \# 1) agree with the enriched source $\mathrm{C} 1$ and are best displayed in the Tshibinda

546 Volcanic Chain. Low-Ba and high-Zr values (trend \# 2), observed in tholeiitic lavas, comply

547 with the $\mathrm{C} 2$ less enriched source. Thus, the double source model can be assumed.

548 Intermediate trends and scattering of plots are explained by varying contributions of the two

549 sources.

550 Existence of two source components is inferred from Sr-Nd isotopes (Furman and Graham, 551 1999). The lavas define a Sr-Nd isotope array between a high ${ }^{143 / 144} \mathrm{Nd}$ and low ${ }^{87 / 86} \mathrm{Sr}$ end-

552 member and a low ${ }^{143 / 144} \mathrm{Nd}$ and high ${ }^{87 / 86} \mathrm{Sr}$ end-member. The latter end-member

553 characterizes Tshibinda lavas, and complies with the $\mathrm{C} 1$ enriched source, that is the main

554 source of these lavas. Further isotope features including the East Africa data by Furman and

555 Graham (1999) indicate that this end-member belongs to the continental lithospheric mantle

556 (CLM). In return, the isotopically depleted end-member is allotted to sub-lithospheric source.

557 Its isotope values correspond to an asthenospheric mantle source much more depleted than the

558 C2 source and close to the FOZO composition as redefined by Stracke et al. (2005). Then, the

559 C2 composition is not an end-member, but probably a mixture of asthenospheric and

560 lithospheric (C1) components.

561 In short, diversity of South-Kivu magmas results from interplay of three parameters: 1)

562 mixing of two source components, a lithospheric enriched component and a sub-lithospheric

563 (asthenospheric) less enriched or depleted component; 2) varying degree of partial melting as

564 a function of melt depth; 3) modal composition of the melted source with varying amount of

565 garnet. It is concluded that the South-Kivu magmas were generated in the sub-continental

566 mantle at depth surrounding $80 \mathrm{~km}$ (spinel-garnet transition zone) with important degree of

567 partial melting for tholeiites, and slightly below $80 \mathrm{~km}$, with low degree of partial melting for

568 basanites. Olivine- and alkaline-basalts were produced under intermediate conditions. It can

569 be assumed that the magma genesis was initiated by upwelling of asthenospheric hot material

570 and by decompression linked to extensional tectonic regime of the rift area.

571

572

\subsubsection{The Tshibinda Volcanic Chain}

573

574 According to previous chemical data (Meyer and Burette, 1957; Pouclet, 1976; Guibert, 575 1977; Villeneuve, 1978; Kampunzu et al., 1979; Bellon and Pouclet, 1980; Pasteels et al., 
576 1989), the lavas of the Tshibinda Volcanic Chain (TVC) share the composition of olivine

577 basalt and alkaline-olivine basalt similar to that of the Mio-Pliocene alkaline lavas (Fig. 7).

578 However, on the base of four samples from south of the volcanic chain, Furman and Graham

579 (1999) emphasize significant differences in some trace element abundances between the

580 Tshibinda lavas and the other South-Kivu lavas (higher $\mathrm{Th} / \mathrm{Nb}, \mathrm{Nb} / \mathrm{Zr}, \mathrm{Ba} / \mathrm{La}, \mathrm{Ba} / \mathrm{Nb}$ ), while

$581 \mathrm{Sr}$ and Nd isotope ratios show that Tshibinda lavas form an end-member in the South-Kivu

582 suite.

583 To better document the chemical data, we carried out new analyses along the chain (Table

584 1, Fig. 4). Compared with the South-Kivu alkaline lavas, the TVC lavas are significantly less

585 enriched in less mobile HFS elements, but relatively more enriched in Ba (Fig. 8B). These

586 features are exposed in the $\mathrm{Nb}$ versus $\mathrm{Zr}$ and $\mathrm{Ba}$ versus La covariation diagrams of Figure 11.

587 Tshibinda magma resulted from 4 to $2.5 \%$ of partial melting of the $\mathrm{C} 1$ lithospheric source as

588 discussed above (Fig. 9B). HREE fractionation points to low amount of garnet (Fig. 8B).

589 Indeed, the $\mathrm{Tb}_{\mathrm{N}} / \mathrm{Yb}_{\mathrm{N}}$ ratio ranges from 1.41 to 1.85 , the higher values corresponding to the

590 more alkali basalts. The source melted in upper level of the spinel-garnet transition zone.

591 Chemical variations along the chain can be explained by increasing of melting degree from

592 south (Tshibinda volcanoes) to the middle part (Tshibati volcanoes). However, in the northern

593 part of the TVC, the Leymera volcanoes, which are set after a volcanic gap of $8 \mathrm{~km}$ (Fig. 4),

594 show different chemical (Fig. 11) and isotopical features (Furman and Graham, 1999). The

595 Leymera lava has more $\mathrm{Zr}$, less $\mathrm{Th}$, and is isotopically depleted. This feature is close to the

596 depleted end-member attributed to upwelling asthenosphere, which is absent in the rest of the

597 TVC. This strong difference in a single magmatic event exemplifies heterogeneity of the

598 sources that resulted from mingling of asthenospheric blobs dispersed in the lithosphere.

599

600

\subsection{North-Idjwi lavas}

601

602

603

To the northern tip of Idjwi Island, two decametre-sized outcrops of maftic lava are

604 situated on a hill above the Lake Kivu shore and in a small island, two miles from the

605 mainland. These outcrops are residues of an old volcanic cover. The rock, a nephelinite,

606 displays an intergranular texture with microphenocrysts of olivine and diopside in a nepheline-rich groundmass. Compositionally, the rock is highly undersaturated and sodic-

607 rich (Bellon and Pouclet, 1980; Marcelot et al., 1989; Table 1; Fig. 7). Similar nephelinitic

608 lava occurs on the upper western edge of the rift, in the Numbi area (Fig. 1) (Agassiz, 1954).

609 But, unfortunately, we were not able to sample these outcrops. The Primitive Mantle 
610 normalized incompatible element pattern (Fig. 12) shows high incompatible element

611 abundances and strong fractionation $(64<\mathrm{La} / \mathrm{Yb}<67)$ indicating low degree of melting of an

612 enriched source. This source is clearly related to the garnet-lherzolite mantle (Figs. 9, 11A)

613 complying with high values of the $\mathrm{Tb}_{\mathrm{N}} / \mathrm{Yb}_{\mathrm{N}}$ ratio from 2.41 to 2.50 . The partial melting

614 degree is calculated at $2 \%$.

615 Structural position of these nephelinites is peculiar in the Kivu Rift, far north to the South-

616 Kivu volcanic area, and south to the Virunga area beyond the Lake Kivu. The nephelinites

617 have been K-Ar dated at $28 \mathrm{Ma}$ (Bellon and Pouclet, 1980). A new K-Ar age shows that the

618 lavas are ca. $21 \mathrm{Ma}$ (also see forward, geochronological section). Consequently, the first

619 volcanic activity related to the western branch of the rift was nephelinitic, and took place

620 somewhere between the South-Kivu and Virunga areas, a long time before the rifting and the

621 Lake Kivu formation.

622

623

\subsection{Pre-Virunga lavas}

624

625

626

The Middle Miocene Pre-Virunga lavas consist of dismembered flows roosted on the western edge of the rift. Flows are cut by the Mushebele and Tongo faults (Fig. 6). First petrographical and chemical data allocated these lavas to basaltic alkaline and sodic series (Denaeyer, 1960; Pouclet, 1976). But, some other analyses were used to assume the presence of olivine-tholeiites (Kampunzu et al., 1983, 1998b), which is not supported by petrographical data. However, it is fitting to discard altered samples having high loss on ignition and displaying a false tholeiitic norm composition. Using criteria given above in the South-Kivu section, all the suspected lavas are olivine basalts and not tholeiites. We performed new analyses in the Bishusha and Tongo sectors (Fig. 6; Table 1). All the lavas belong to a sodicrich basanite series highly fractionated in the light rare earth elements $(44<\mathrm{La} / \mathrm{Yb}<49), \mathrm{Nb}$, Th, and Ba (Fig. 12). The convenient source must be garnet lherzolite (Fig. 9) taking into account high value of the $T b_{N} / \mathrm{Yb}_{\mathrm{N}}$ ratio of 2.92. This source may be the same than the lithospheric source of South-Kivu, but with smaller partial melting degrees of $4 \%$ to $2 \%$.

In the Tongo sector, the new analyses confirm the presence of mugearite and benmoreite evolved lavas, and thus the occurrence of crustal reservoirs where differentiation processes could have worked. This implies a focusing of a long-lasting source melting.

An intriguing question is the initial geographical distribution of Pre-Virunga lavas.

642 Present-day location of these lavas is limited to western upper step of the rift, west of Tongo

643 Fault. Similar old lavas are totally lacking in the eastern edge, namely in the Muhungwe area. 
644 But one may assume that such lavas may have poured out above the lower steps of the rift, 645 presently overlain by the recent Virunga volcanoes. If it is the case, these lavas must have 646 been sampled by the numerous eruptions of Virunga, and may be collected as xenoliths, like 647 any basement rocks, in the Quaternary Virunga lavas. We have investigated the 107 flank and 648 parasitic cones of Nyamuragira, many flank cones of Nyiragongo, and the Nyamuragira and 649 Nyiragongo calderas. All our collected xenoliths (excluding the cognate xenoliths) only 650 consist of quartzites, shales, and micaschists in the Nyamuragira sector and of granite in the 651 Nyiragongo sector. No Pre-Virunga-like basalts were sampled. Only one sample of basaltic 652 lava has been found in 1959, as ejected block in the inner pit of Nyiragongo. Petrography of 653 this sample was done by Sahama (1978), but without any chemical analysis. The origin of this 654 "basalt" remains questionable. It is concluded that the Pre-Virunga magmatic activity was 655 restricted to the west part of the rift, between 13 and $9 \mathrm{Ma}$ and before the rift valley

656 formation. Volcanic activity of the Virunga area along the rift axis only began in the late 657 Pliocene.

658 To the west of the rift, close to Pre-Virunga lavas, the Mweso lava flow has run along the 659 valley, from south-east to north-west (Figs. 1, 5, 6). This flow highly post-dated the Pre-

660 Virunga lavas that crop out at the hilltops. It is overlain by recent flows from Nyamuragira

661 parasitic events. Poor chemical data are available for this lava flow (Table 1). However, its

662 alkaline content is close to that of the neighbouring Nyamuragira lavas that belong to a 663 potassic basanite series, and is very different to the sodic series of Pre-Virunga lavas.

664

665

\subsection{Virunga lavas}

666

667

Virunga lavas exhibit many outstanding compositions, such as high-potassium content

668 shared with lavas of north part of the Kivu Rift in the Toro-Ankole volcanic area, but

669 unmatched by any other lavas of the East African Rift, except some nephelinites and

670 melilitites of North Tanzania. In this section, the analyzed rocks are distributed according their petrographical features in a simplified nomenclature. The geochemical groups are defined and the question of their magma sources is discussed.

673

674

\subsubsection{Magma compositions}

675

676

Virunga lavas are characterized by a potassic magmatic signature, but range in two 677 contrasting series: a leucite basanite series and a leucite-melilite nephelinite series, illustrated 
678 by the two currently active volcanoes, Nyamuragira and Nyiragongo. Because the

679 nomenclature of potassic lavas was imprecise and confusing, we proposed a simplified

680 taxonomic system (Pouclet, 1980, b; Pouclet et al., 1981, 1983, 1984) that has been adopted

681 in most of the following studies of the Virunga lavas. We use the K-prefixed rock names of

682 the sodic series commonly known in the international community: K-basanite, K-hawaiite, K-

683 mugearite, K-benmoreite, and K-trachyte. Limits of the terms are defined by the

684 differentiation index (DI) of Thornton and Tuttle (1960) values of 35, 50, 65, and 80. The

685 more mafic terms (DI < 25) enriched in phenocrystic olivine and/or pyroxene, are named K-

686 limburgite and K-ankaratrite, respectively. The K-basanite and K-hawaiite correspond to local

687 terms of porphyritic kivite and kivite, respectively. The feldspathoid-rich lavas are named

688 after their main mineral contents: olivine melilitite, olivine nephelinite, nepheline melilitite,

689 melilite-leucite nephelinite, leucite nephelinite, and nepheline leucitite.

690 The leucite basanite series is located at Nyamuragira, Karisimbi, old Visoke, Sabinyo,

691 Gahinga, and Muhavura. It is suspected at Shaheru. The leucite-melilite nephelinite series is

692 located at Nyiragongo, Baruta, Mikeno, and young Visoke. Various compositions of these

693 volcanoes are depicted by the Primitive Mantle normalized trace element diagrams (Fig. 13).

694 Chemical data are given by Hertogen et al. (1985), De Mulder et al. (1986), Marcelot et al.

695 (1989), Toscani et al. (1990), Rogers et al. (1992), Rogers et al. (1998), Platz et al. (2004),

696 Chakrabarti et al. (2009a), and by new analyses (Table 1).

697 Nyamuragira lavas are characterized by moderate enrichment of large ion lithophile

698 elements (LILE; La/Yb = 25-34), slight Sr-negative anomaly, and HREE depletion with

$699 \mathrm{~Tb} / \mathrm{Yb}_{\mathrm{N}}$ ratios ranging from 1.95 to 2.24 (Fig. 13A). All the mobile LILE are equally

700 moderately enriched, including $\mathrm{Rb}$. This last feature distinguishes the Nyamuragira-related

701 western lavas of Kamatembe (N46) and Mushari (N572) from the Pre-Virunga lavas (Table 1;

702 Figs. 5 and 6). These two successive magmatic activities (Pre-Virunga and W-Nyamuragira)

703 came from very different sources (Figs. 12 and 13A). Compared to Pre-Virunga lavas, the

704 Nyamuragira lavas are less enriched in LILEs with the noticeable exception of Rb. The

705 basanitic volcanoes Karisimbi, early Visoke, Sabinyo, Gahinga, and Muhavura share the same

706 trace-element patterns with Nyamuragira (Fig. 13B), though their evolved lavas are normally

707 more enriched in the whole incompatible elements.

708 Nyiragongo lavas are much more enriched in incompatible elements than Nyamuragira

709 lavas (Fig. 13C). Their La/Yb ratios range from 43 to 58 in the olivine nephelinites, 54 to 69

710 in the nephelinites and leucitites, and 63 to 73 in the melilitites. They are depleted in HREEs

711 with $\mathrm{Tb} / \mathrm{Yb}_{\mathrm{N}}$ ranging from 1.93 to 2.86. A peculiar feature is the prominent depletion in Hf. 
712 The other leucite nephelinite volcanoes, Baruta, Mikeno and young Visoke, share similar

713 composition (Fig. 13D). It is worth noting that melilitites are the most enriched in

714 incompatible elements. Leucite-rich leucitites show $\mathrm{Rb}$ (and $\mathrm{K}$ ) enrichment and $\mathrm{Ti}$ (and $\mathrm{Mg}$,

715 Fe) depletion, but also high Hf depletion.

716 In Virunga lavas, HREE depletion points to low degree of partial melting with residual

717 garnet in the source. By using similar approach than for the South-Kivu lavas, the magmatic

718 source of the Virunga lavas may be a garnet peridotite with low or no content of spinel (Fig.

719 14). The nephelinitic magma originated from lower degree of partial melting than the

720 basanitic magma.

721 Both $\mathrm{K}$ and $\mathrm{Rb}$ enrichments suggest the presence of phlogopite in the source (Furman,

722 2007), while low to moderate values of the $\mathrm{K} / \mathrm{Rb}$ ratio (70-174 in K-basanite series and 117 -

723202 in K-nephelinite series) preclude an amphibole-bearing source, as emphasized by

724 Chakrabarti et al. (2009a and b). In the $\mathrm{Ba} / \mathrm{Rb}$ vs. Rb/Sr diagram of Furman et al. (2006),

725 elevated $\mathrm{Rb} / \mathrm{Sr}$ ratios may indicate phlogopite or carbonatite metasomatism. High values are

726 recorded in the K-basanite series $(\mathrm{Rb} / \mathrm{Sr}=0.06-0.11)$, excluding the crustal contaminated

727 evolved lavas analyzed by De Mulder et al. (1986) and by Rogers et al. (1998), while the

728 values of the $\mathrm{K}$-nephelinite series are moderate $(\mathrm{Rb} / \mathrm{Sr}=0.04-0.09) . \mathrm{Zr} / \mathrm{Hf}$ ratios (41-47) of

729 the K-basanites are consistent with low partial melting of a garnet-clinopyroxene bearing

730 mantle source (Dupuy et al., 1992; Chakrabarti et al., 2009a) and do not indicate carbonate

731 contribution. A phlogopite contribution is retained for K-basanites. Very high $\mathrm{Zr} / \mathrm{Hf}$ ratios in

732 the Nyiragongo leucite-nephelinites and leucitites $(\mathrm{Zr} / \mathrm{Hf}=47-94)$ may be a consequence of

733 carbonatite metasomatism (Dupuy et al., 1992). We show that high $\mathrm{Zr} / \mathrm{Hf}$ values are due to Hf

734 depletion (Fig. 15). This implies contribution of a Hf-poor component in the Nyiragongo

735 source. According to analytical data of Andrade et al. (2002), Zr- and Hf-contents in

736 carbonatites display very large range of values and ratios. This is explained by heterogeneities

737 in the mantle source that are amplified by very low degrees of partial melting of the

738 carbonatite melt. Hf-poor carbonatites with super-chondritic $\mathrm{Zr} / \mathrm{Hf}$ ratios occurred in Brazilian

739 and Namibian Cretaceous complexes, and in the Oldoinyo Lengai volcano of Tanzania (Fig.

740 15) (Andrade et al., 2002). In the Quaternary carbonatite lava of Fort-Portal in the Toro-

741 Ankole volcanic area, northern end of Western Rift, the $\mathrm{Zr} / \mathrm{Hf}$ ratio is 78 (Eby et al., 2009). In

742 the Namibian Kalkfeld Carbonatite Complex, associated nephelinites exhibit Zr and Hf

743 contents close to those of Nyiragongo nephelinites (Fig. 15). In this Complex, the carbonatite

744 melt contribution to nephelinitic magma has been demonstrated (Andrade et al., 2002). It is

745 concluded that the Nyiragongo nephelinitic magma is mixed with a carbonatite melt. 
In summary, K-basanite lavas originated from melting of a garnet- and phlogopite-bearing source. According to both garnet and phlogopite stabitity fields in the mantle, the melt depth must be between 80 and $150 \mathrm{~km}$ (Chakrabarti et al., 2009a). K-nephelinite series may be derived from the same source, with lower partial melting degree. But, in the Nyiragongo area, this magma has been contaminated by a carbonate component. The questions are: what is the origin of this component, and why very neighbouring volcanoes, Nyamuragira and Nyiragongo, may exhibit very different chemical composition, only one being contaminated?

Chakrabarti et al. (2009a) suggest two distinct melting of a very distant heterogeneous plume.

754

755

756

757

758

759

760

761

762

763

764

765

766

767

768

769

770

771

772

773

774

775

776

777

778

779

This model needs two different channelling in a very long distance for the spatially adjacent volcanoes, and also for the other Virunga volcanoes. Thus, it seems to be an improbable process. It is useful to re-examine the question of the Virunga heterogeneous source, because until now, there is no convincing model.

\subsubsection{The carbonatite deal and the sources of Virunga volcanoes}

Carbonate metasomatism in Nyiragongo lavas is an old hypothesis for the Virunga magma genesis to explain high alkali and lithophile element contents. Some authors also underline the possible contribution of the crust, without or with carbonatite (Higazy, 1954; Holmes, 1965; Bell and Powell, 1969). Others favour the role of a carbonatite melt (Dawson, 1964) or a volatile transfer (Sahama, 1973). Petrological analyses ruled out the crust contribution (Pouclet, 1973). The isotopic studies gave decisive data. Th isotope ratios are consistent with carbonate metasomatism beneath Nyiragongo according to Williams and Gill (1992). Nd, Sr, and $\mathrm{Pb}$ isotope systematics of Nyiragongo nephelinites imply that a previous fluid contamination and LILE enrichment of the source has occurred around $500 \mathrm{Ma}$ ago (Vollmer and Norry, 1983; Vollmer et al., 1985) or between 750 and $850 \mathrm{Ma}$ (Rogers et al., 1992). The style of enrichment could be common metasomatism by mobile fluid or, more probably, melt addition before and during magma genesis (Rogers et al., 1992; Williams and Gill, 1992).

Fluid and solid inclusions in Nyiragongo melilites shows that the lava was in equilibrium with a carbonatitic liquid (Louaradi, 1994). The opportunity of carbonatitic enrichment is supported by neighbouring occurrence of the nepheline syenite-carbonatite intrusive complex of Lueshe dated at $619 \pm 42$ Ma by Van Overbeke et al. (1996) and at $558 \pm 11$ by Kramm et al. (1997). We discard the $822 \pm 120$ Ma date of Kampunzu et al. (1998a) having a bad mean square of weighted deviates (MSWD). Coincidently, large flakes of biotite developed close to cancrinite-bearing syenite, in the Lueshe pyrochlore-rich sövite, display a K-Ar age of $516 \pm$ 
$26 \mathrm{Ma}$ (Bellon and Pouclet, 1980). The Lueshe complex is associated with, at least, four alkaline syenitic intrusions of similar Late Neoproterozoic ages, in the neighbouring westVirunga area (Kirumba, Bishusha, Fumbwe, Numbi, Fig. 16). The cancrinite- and sodalitebearing syenite of Kirumba is partly rimed with a thin fringe of ankeritic carbonatite. Occurrence of pyrochlore in the alkaline syenite of Numbi suggests a close association with a carbonatite body. Hence, alkaline fluids have contaminated many parts of the sub-continental mantle in the Virunga area at the time of the carbonatite-syenite magmatic activities.

We tentatively locate the potassium-enriched mantle beneath the Virunga volcanic system as a function of magma fingerprints of the different volcanic activities. This mantle extends WSW-ENE from the south-western and western small volcanoes: Nahimbi, Rumoka, Rushayo, Suri-Turunga and Muvo (Nh, Rm, Rs, St, Mv) which are the sites of the most primitive magmas (K-limburgites and olivine-melilitites or "rushayites") fed by independent tectonic drains unrelated to the tectonic system of the great volcanoes, to the north-east Bufumbiro Bay (Bf) small volcanoes of primitive lavas (K-limburgites or "ugandites" and Kankaratrites or "murambites"), which were directly fed by their own drains with no magmatic relationships to the neighbouring Muhavura (Fig. 16). This mantle source area includes the more enriched carbonate core extending from Nyiragongo-Baruta to Mikeno and Visoke. The Virunga volcanism began after the uplift of the west (Tongo) and east (Muhungwe) borders, and the sinking of the Kivu and Edward basins dated around $5 \mathrm{Ma}$. We assume that the early activity took place along the SW-NE oblique zone of the anomalous mantle underlining the offset of rift axis, because the Mikeno emplaced in the middle part of this zone ca. 2 Ma.

The melting depth increased from the western uplifted rift edges (1) to the upper-middle steps (2) and the lower step (3) of the rift valley with the following magma genesis: 1) preVirunga sodic basalt, 2) potassic basanite of Nyamuragira and eastern volcanoes, and 3) potassic nephenilite of Nyiragongo, Mikeno and Visoke. Hence the metasomatised mantle was melted at the deepest level of magma genesis of the Virunga area. Similar melting is exhibited in the northern part of the Kivu rift, in the Toro-Ankole volcanic area characterised by highly alkaline, potassic and carbonated lavas defining the kamafungite series. The kamafungite magma genesis implied important contribution of the potassium-rich and carbonatitic component from very deep metasomatised source (Rosenthal et al., 2009).

In the eastern rift, the most K-enriched alkaline lavas are located in northern Tanzania

\section{Archaean Tanzanian craton and the Palaeo and Neoproterozoic Ungaran and Mozambique}

813 belts. Volcanoes emplaced on the craton and the remobilized craton margin and exhibit K- 
814 nephelinites and melilitites similar to the Virunga ones, and also carbonatites similar to the

815 Toro-Ankole ones (Le Bas, 1981, 1987). A carbonatite metasomatism has been evidenced

816 from mantle xenoliths originated from the lithospheric craton root (Rudnick et al., 1993).

817 Isotopic compositions suggest that the metasomatism occurred recently. The carbonatite was

818 generated either by melting lithosphere that had become carbonated by asthenosphere-derived

819 melts, or directly from the asthenosphere in relationship with the mantle plume heating.

820 In the Kivu rift, isotope data suggest an older carbonatitic event, may be Neoproterozoic

821 (Vollmer and Norry, 1983; Vollmer et al., 1985; Rogers et al., 1992). But, we cannot exclude

822 the contribution of a volatile-rich transfer from the hot upwelling asthenosphere. In the Toro-

823 Ankole field, Nd, Sr and Hf isotope arrays suggest two time-spaced enrichments of the

824 source: a potassic alkaline silicate metasomatism and later a carbonate-rich metasomatism

825 (Rosenthal et al., 2009).

826 To comply with these data, we conclude that the distribution of geochemical variations in

827 the Virunga area is explained by zoning of a lithosphere enrichment that has occurred during

828 a Neoproterozoic alkaline magmatic event and by the contribution of plume-related hot and

829 fluid-rich asthenospheric components.

830

831 4. Geochronology and history of the rift

832

833 4.1. Previous data

834

835 Reliable K-Ar geochronological data are provided by Bagdasaryan et al. (1973), Guibert et 836 al. (1975), Bellon and Pouclet (1980), Rançon and Demange (1983), De Mulder (1985), De

837 Mulder and Pasteels (1986), Pasteels et al. (1989), and Kampunzu et al. (1998b). Some Ar/Ar 838 ages of the Sabinyo and Muhavura volcanoes were obtained by Rogers et al. (1998).

839 There is a consensus about a three stages volcanic story of the South-Kivu area. Activity

840 began around $10 \mathrm{Ma}$ with outpouring of tholeiites and olivine-tholeiites. While this tholeiitic

841 production seems to decline, the magma evolves to an alkali basaltic composition, around 8

842 Ma. A new rising alkaline activity, the second stage, took place between 7 and 4 Ma. These

843 Miocene to Pliocene activities supplied the main part of the basaltic pile of the South-Kivu

844 area. The third stage consists of strombolian eruptions of the Tshibinda Chain, in the early

845 Pleistocene. Around the Virunga area the Pre-Virunga activity is dated between 13 and 9 Ma.

846 Activities of the Virunga main volcanoes are dated from 2.6 Ma to present time (see section

847 2.3.). 
The northernmost volcanic area of Toro-Ankole, north-east of Lake Edward, is

849

850

851

852

853

854

855

856

857

858

859

860

861

862

863

864

865

866

867

868

869

870

871

872

873

874

875

876

877

878

879

880

881 approximately dated to the Late Quaternary, with some accurate ages between 50 and $10 \mathrm{ka}$ after Boven et al. (1998).

\subsection{New K-Ar age data}

We display a new set of 17 whole rock K-Ar determinations (Table 2). Samples locate from north and south of Idjwi Island, Bitare-Bugarama graben, Bukavu graben (Cyanguguupper Rusizi), and western upper edge of the rift (Fig. 17).

We paid a special attention to the Idjwi Island where we previously obtained very old ages (Bellon and Pouclet, 1980) not supported by further studies (Pasteels and Boven, 1989; Pasteels et al., 1989).

The small outcrops of nephelinite lava were sampled north of Idjwi Island. They are residues of an old flow cover (see above). First dating yielded $28 \pm 1.4 \mathrm{Ma}$, a rather old age that has been declared "not reliable" by Kampunzu et al. (1998b). Enrichment of radiogenic argon may be suspected. A new measurement (LKa4) indicates $19.98 \pm 1.00 \mathrm{Ma}$. One another sample (BK8) of the same lava gives a similar age of $20.97 \pm 0.56 \mathrm{Ma}$. According these new data, an early Miocene nephelinitic activity is proved. It took place between the South-Kivu area and the Virunga area, before the birth of the Lake Kivu (dated ca. $5 \mathrm{Ma}$ ) that separates the two areas.

The southern Idjwi Island is partly covered with tholeiitic and alkali basaltic flows belonging to the South-Kivu volcanic area. Tholeiites poured out over the crystalline basement and are overlain by alkali basalts. In two places, tholeiitic flows are linked to accumulations of hyaloclastites that are remnants of under-water volcanic cones. They are also few small outcrops of diatomite-rich lacustrine deposits that are dated to the early Holocene by their diatom composition. These last deposits were produced when the Lake Kivu has reached its highest level, between 10 and 8 ka B.P., before the digging of the Rusizi canyon (Pouclet, 1975) and thus are not related to the hyaloclastites. New ages measurements of tholeiite flows yield ages of $10.30 \pm 0.35,9.56 \pm 0.48,8.76 \pm 0.44,7.73 \pm 0.30$ and $6.62 \pm$ $0.66 \mathrm{Ma}(\mathrm{BK} 14,19,15,36$ and 7, respectively). An alkali basalt (BK-18) overlying the tholeiites is dated at $7.07 \pm 0.51 \mathrm{Ma}$.

Finally, what could be the true age for this tholeiitic activity? An analytical study of argon behaviour in similar tholeiitic lavas from South-Idjwi has been conducted by Pasteels and Boven (1989). Apparent ages were obtained from 16.9 to 3.9 Ma. The authors concluded to 
882 the presence of excess argon and discarded the older ages. They dated to 4.1 Ma a sample of 883 alkali basalt overlying tholeiites, and suggested that tholeiite activity may be as young as 5

884 Ma. It is known that sample preparation for K-Ar analyses cannot totally eliminate 885 xenocrystic fragments of the substratum that cause argon gain leading to old apparent ages. 886 Conversely, alteration is responsible for potassium and radiogenic argon losses that likely 887 make the ages younger. Unfortunately, South-Kivu tholeiites are rich in vitreous groundmass 888 containing most of the potassium and radiogenic argon, and this groundmass is easily altered. 889 So, young ages are not more credible than the old ones. Taking up to 7.07 Ma the age of the 890 overlying (fresh and not vitreous) olivine basalt, the South-Idjwi tholeiites must be dated 891 between 10.3 and $7 \mathrm{Ma}$, owing to our new datings.

892 To document the question of initial tholeiitic activity of South-Kivu area, tholeiites from 893 the on-land southern prolongation of South-Idjwi lavas (RW86, 87) have been analyzed by 894 one of us (H.B.) and age results were listed in Marcelot et al., (1989). Respectively, the 895 following results are obtained: $8.97 \pm 0.45$, and $11.42 \pm 0.57$. These results are consistent with 896 previous age data of tholeiites from upper Rusizi (10.0 to 7.6 Ma; Pasteels et al., 1989), and 897 from the western edges (8.2 to 6.9 Ma; Kampunzu et al., 1998b).

898 Additional alkali basalts were dated in the middle part of the rift (Fig. 17): Bugarama 899 graben (RW88, 83) $10.63 \pm 0.53$ and $7.75 \pm 0.39 \mathrm{Ma}$, and upper Rusizi area (RW90, 89, 82, 900 81) $8.10 \pm 0.40,7.68 \pm 0.38,7.18 \pm 0.36$, and $6.33 \pm 0.32 \mathrm{Ma}$. Of important are the lavas of 901 the Kahuzi fracture zone, which are cross-cut by the main faults of the western upper steps. A 902 dating (MM2) gives $8.19 \pm 0.40 \mathrm{Ma}$ (Figs. 1, 3).

903

904

\subsection{Geodynamical history of the rift}

905

906

907

Taking into account the revised and the new data, in addition to the previously published data (Bagdasaryan et al., 1973; Guibert et al., 1975; Bellon and Pouclet, 1980; Pasteels and Boven, 1989; Pasteels et al., 1989; Kampunzu et al., 1998b) there is a total of $67 \mathrm{~K}-\mathrm{Ar}$ ages for South-Kivu, pre-Virunga, and Mikeno lavas (Table 4). We exclude the post-1 Ma young lavas. These ages are plotted on a histogram in Figure 18.

912

The earliest volcanic event happened around $21 \mathrm{Ma}$ in the North-Idjwi, close to the future

913 this first activity are hidden by the South-Kivu and Virunga lavas. These early Miocene lavas

914 are strongly alkaline and nephelinitic and resulted from a very low partial melting of mantle

915 source. At that time, the rift valley did not exist and no swell is evidenced. A large outcrop of 
916 old nephelinites is located west of the Lake Kivu, close to an alkaline syenite intrusion

917 (Numbi, Fig. 16) belonging to the Neoproterozoic anorogenic alkaline activity already

918 checked in the Kahuzi area, and west of the Virunga. The alkaline intrusions are set along a

919 NNE-SSW striking line named "the Neoproterozoic Weakness Line" (Fig. 19A). It is

920 postulated that the initial volcanic activity of the Kivu Rift, as well as the Pre-Virunga early

921 activity was drained by such an inherited fracture zone.

922 We indicate that, in the Kivu Rift, volcanism began contemporaneously with that of the

923 Kenya Rift ca. $23 \mathrm{Ma}$ (Hendrie et al., 1994) and of southern Ethiopia ca. $21 \mathrm{Ma}$ (George and

924 Rogers, 2002), though the earliest magmatism of the eastern rift is dated at $45 \mathrm{Ma}$ in the main

925 rift Ethiopia (George et al., 1998). Our data rectify common belief that the Western Rift

926 volcanism began 5-10 m.y. after the Kenya Rift volcanism.

927 Pre-Virunga volcanic activity took place between 13 and 9 Ma. It is located in the

928 Neoproterozoic Weakness Line, and controlled by NW-SE faults oblique to the rift axis

929 (Fig.19A). The Tongo Fault was not yet active. The existence of a crustal magma chamber

930 beneath this volcanic field is attested by the output of evolved lavas. The composition is

931 alkaline sodic and indicates a low degree of melting of the source.

932 At ca. $11 \mathrm{Ma}$, tholeiitic volcanism was emplaced in the South-Kivu, along the South-Idjwi

933 - Bitare-Bugarama structure, parallel to the rift axis (Fig. 19). Flows poured out along a

934 north-south fracture system. Besides, the 8.2 Ma Kahuzi flow (MM2) to the edge of the upper

935 step ran down to the west. This flow direction complies with the existence of a swell and with

936 the absence of a rift graben. However, the tholeiitic underwater hyaloclastites and flows of

937 South-Idjwi, which are dated around $8 \mathrm{Ma}$, involve the existence of a lacustrine basin. It must

938 be assumed that a first, though limited graben was formed along the rift axis, at ca. $8 \mathrm{Ma}$.

939 Afterwards, the tholeiite magma contribution decreased until $5 \mathrm{Ma}$, but was no longer

940 restricted to the rift axis. Last tholeiitic lavas poured out on the western upper Kahuzi step and

941 on the Mwenga area where they are overlain by 5.8 to $2.6 \mathrm{Ma}$ alkaline lavas (Fig. 19). In the

942 same time, since 10.6 Ma or 8.5 Ma, an alkaline magma production resulted from less partial

943 melting of a heterogeneous source. The activity was located along the Bugarama north-south

944 tectonic axis, and then, along the N-S and NNE-SSW trending faults of the whole area. The

945 most significant basaltic supply is dated between 8 and 7 Ma. The alkali basalt lava flew

946 down above the western steps of the rift. Their local unconformity above the tholeiites in the

947 Bugarama graben confirm that the rift valley was initiated around $8 \mathrm{Ma}$. Subsidence of the

948 northern basin of Lake Kivu began ca. 5 Ma. Between 6 and 5 Ma, extrusion of evolved lavas

949 (trachyte-phonolite), into and close to the Bukavu graben, pointed to the ponding of alkaline 
950 magma into crustal reservoirs in a limited area. After $5 \mathrm{Ma}$, volcanic activity decreased and

951 migrated to the south-west tectonic zone of Mwenga until 2.6 Ma, in correlation with the

952 decreasing of the partial melting degree of the source which produced Mg-basanites. Such a

953 timing and the magmatic feature are consistent with a rift propagation in the Mwenga branch.

954 The last activity, around 1.7 Ma, has built the Tshibinda Chain at the edge of Mount Kahuzi.

955 Its alkaline lavas imply a new and moderate degree of melting of a similar source.

956 Consequently, a thermal anomaly was persisting below the higher western part of the rift in

957 the Lake Kivu area. More recent eruptions (possibly late Pleistocene) in the Tshibinda Chain

958 and Rwandese shore lake have been assumed by Pasteels et al. (1989) and by Ebinger

959 (1989a). However, new accurate chronological data are needed to improve the temporal

960 constraints of these latest eruptions.

961 In the Virunga area above the shelf between lakes Kivu and Edward, volcanic activity was

962 initiated along a SW-NE fracture zone at the Mikeno area, ca. 2.6 Ma (Guibert et al., 1975),

963 and then propagated to the SW at the Shaheru, and to the NE at the early-Visoke, early-

964 Karisimbi, Sabinyo, Gahinga and Muhavura until to 0.1 Ma (Bagdasaryan et al., 1973;

965 Rançon and Demange, 1983; Rogers et al., 1998). In recent time, volcanism occurred

966 simultaneously in the eastern side at young-Visoke, Karisimbi and Muhavura (Rançon and

967 Demange, 1983; De Mulder, 1985; Rogers et al., 1998), and in the middle area, at Baruta.

968 Lastly, eruptions were focused in the middle Virunga at Nyiragongo, and to the west at

969 Nyamuragira.

970

971

\section{Conclusions}

972

973

This study addresses the tectonic pattern, volcanic rock compositions, and age dating of the

974 Kivu Rift in the western branch of the East African Rift system, with the aim of improving the

975 history of the rift and deciphering the relationships between the volcano-tectonic pattern and

976 the conditions of magma genesis.

977 The rift resulted from stretching of the continental lithosphere that produced thinning and

978 passive upwelling of hot asthenosphere. The tectonic framework evolved with linking of fault

979 segments inherited from weakness zones of the basement, and with development of isolated

980 basins in the rift axis. Rising of the top of the asthenosphere with thinning of the lithospheric

981 mantle initiated the decompressional driven partial melting of the lithosphere and

982 asthenosphere, successively. This first pre-rift doming stage is portrayed with the $21 \mathrm{Ma}$

983 nephelinites of North-Idjwi, the 13-9 Ma alkaline basalts of West-Virunga, and the 11-8 Ma 
984 tholeiites of South-Kivu. At that time, no fault scarps were developed and the rift valley was

985 not yet created, though a small lacustrine basin existed in the South Idjwi area owing to the

986 occurrence of hyaloclastites. The magma composition logically evolved from highly alkaline

987 to moderately alkaline and to sub-alkaline with increasing amount of lavas, in relationships

988 with increasing degree of partial melting and more important contribution of the

989 asthenospheric component. The N-S and NNW-SSE trend of the fertile fractures suggests an

990 E-W strain field direction.

991 But, in the following stage, the magma production stopped in the Virunga area and

992 completely changed in South Kivu with the outpouring of alkaline basalts, as soon as 8.5 Ma.

993 The partial melting decreased and was limited to lithospheric mantle. One may note the lack

994 of voluminous flood basalts, a salient component of the extensional rifting evolution in the

995 Ethiopian-Somalian branch of the East African rift. Then, the rift valley was created and the

996 lake basins subsided, namely around $5 \mathrm{Ma}$ for the Lake Kivu. This indicates the cessation of

997 the extensional process and the cooling of the underlying mantle, as proved by the decreasing

998 degree of partial melting of the late Pliocene Mg-basanites of the Mwenga branch. The

999 extrusion of differentiated lavas between 6 and $5 \mathrm{Ma}$ in the Bukavu graben, points to magma

1000 storage into crustal reservoir, and to the non-existence of an opened fissural system.

1001 Again, the Kivu rift evolution completely changed when a new highly alkaline and potassic

1002 volcanism appeared in the Virunga site around 2.6 Ma. From that time until now, this event is

1003 controlled by a transtensional constraint and the opening of a tension gash with an ENE-

1004 WSW extensional displacement. This constraint affected the South-Kivu and induced a

1005 moderate melting of the lithosphere in the Tshibinda Volcanic Chain during the Pleistocene.

1006 In the Virunga area, the magmas tapped a deep mantle source previously enriched by

1007 carbonated metasomatism. The success of the melt production is explained by the high

1008 volatile content of the mantle source which facilitated the melting. In the same structural

1009 context, a normal mantle would not melt. In return, the presence of a metasomatized mantle is

1010 the effect of a former Proterozoic magmato-tectonic event which created the structural

1011 weakness zone reactivated and used by the Kivu rift. Thereby, the existence of the

1012 outstanding Virunga volcanic province is not really fortuitous.

1013 The history of the Kivu rift is not a smooth running of a standard rift development. It is

1014 strongly dependent on space and time distribution and changing of the surrounding driving

1015 forces in the African plate. Meanwhile, no accurate correlations can be evidenced with the

1016 eastern branch of East African Rift. Further studies and age datings are needed to attempt a

1017 more comprehensive model of the East African magmato-tectonic evolving constraints. 
We gratefully acknowledge Peter Kunkel, director of the "Institut pour la Recherche en

1022

1023

1024

1025

1026

1027

1028

1029

1030

1031

1032

1033

1034

1035

1036

1037

1038

1039

1040

1041

1042

1043

1044

1045

1046

1047

1048

1049

1050

Afrique Centrale", the former "Centre de Recherches en Sciences Naturelles" (CRSN), for providing facilities during the four years of field studies and for his warmful support. We thank Andrew Conly and Alfred Wittaker for improving the English text.

\section{References}

Agassiz, J.F., 1954. Géologie et pegmatites stannifères de la région de Mumba-Numbi. Comité National du Kivu (Congo) N.S. n 7, 78 pp.

Andrade, F.R.D. de, Möller, P., Dulski P., 2002. Zr/Hf in carbonatites and alkaline rocks: New data and a re-evaluation. Revista Brasileira de Geociências 32, 361-370.

Auchapt, A., 1987. Les elements traces dans les basalts des rifts continentaux : exemple de la province du Sud Kivu (Zaïre) dans le rift Est-Africain. Documents et Travaux du Centre Géologique et Géophysique de Montpellier, France, n 12, 99 pp.

Auchapt, A., Dupuy, C., Dostal, J., Kanika, M., 1987. Geochemistry and petrogenesis of riftrelated volcanics from South Kivu (Zaire). Journal of Volcanological and Geothermal Research 31, 33-46.

Bagdasaryan, G.P., Gerasimovskiy, V.I., Polyakov, A.I., Gukasyan, R.K.H., 1973. Age of volcanic rocks in the rift zones of East Africa. Geochemistry International 10, 66-71.

Bell, K., Powell, J.L., 1969. Strontium isotopic studies of alkalic rocks: The potassium-rich lavas of the Birunga and Toro-Ankole. Journal of Petrology 10, 536-572.

Bellon, H., Pouclet, A., 1980. Datations K-Ar de quelques laves du rift-ouest de l'Afrique Centrale; implications sur l'évolution magmatique et structurale. Geologische Rundschau $69,49-62$.

Bellon H., Quoc Buü N., Chaumont J. and Philippet J.C., 1981. Implantation ionique d'argon dans une cible support: application au traçage isotopique de l'argon contenu dans les minéraux et les roches. Comptes Rendus de l'Académie des Sciences, Paris (France), Série II, 292, 977-980.

Boven, A., Pasteels, P., Punzalan, L.E., Yamba, T.K., Musisi, J.H., 1998. Quaternary perpotassic magmatism in Uganda (Toro-Ankole Volcanic Province): age assessment and 
1051

1052

1053

1054

1055

1056

1057

1058

1059

1060

1061

1062

1063

1064

1065

1066

1067

1068

1069

1070

1071

1072

1073

1074

1075

1076

1077

1078

1079

1080

1081

1082

1083

1084

significance for magmatic evolution along the East African Rift. Journal of African Earth Sciences 26, 463-476.

Boven, A., Theunissen, K., Sklyarov, E., Klerkx, J., Melnikov, A., Mruma, A., Punzalan, L., 1999. Timing of exhumation of a high-pressure mafic granulite terrane of the Paleoproterozoic Ubende belt (West Tanzania). Precambrian Research 93, 119-137.

Brousse, R., Lubala, R.T., Katabarwa, J.-B., 1983. Découverte d'une formation de nuées ardentes dans la région de Ruhengeri au flanc sud du volcan Sabyinyo (chaîne volcanique des Birunga-Rwanda). Comptes Rendus de l'Académie des Sciences, Paris (France), Série II, 297, $623-626$.

Chakrabarti, R., Basu, A.R., Santo, A.P., Tedesco, D., Vaselli, O., 2009a. Isotopic and geochemical evidence for a heterogeneous mantle plume origin of the Virunga volcanics, Western rift, East African Rift system. Chemical Geology 259, 273-289.

Chakrabarti, R., Sims, K.W.W., Basu, A.R., Reagan, M., Durieux, J., 2009b. Timescales of magmatic processes and eruption ages of the Nyiragongo volcanics from ${ }^{238} \mathrm{U}^{230}{ }^{23 h-}{ }^{226} \mathrm{Ra}-$ ${ }^{210} \mathrm{~Pb}$ disequilibria. Earth and Planetary Science Letters 288,149-157.

Dawson, J.B., 1964. Reactivity of the cations in carbonate magmas. Proceedings Geological Association of Canada 15, 103-113.

Degens, E.T., Von Herzen, R.P., Wong, H.-K., Deuser, W.G., Jannash, H.W., 1973. Lake Kivu: structure, chemistry and biology of an East African rift lake. Geologische Rundschau 62, 245-277.

De La Vallée-Poussin, J., 1933. Découverte de nouveaux gisements de lave au Kivu. Bulletin de la Société Belge de Géologie 43, 74-75.

Demant, A., Lestrade, P., Lubala, R.T., Kampunzu, A.B., Durieux, J., 1994. Volcanological, and petrological evolution of Nyiragongo volcano, Virunga volcanic field, Zaire. Bulletin of Volcanology 56, 47-61.

De Mulder, M., 1985. The Karisimbi volcano (Virunga). Musée Royal de l'Afrique Centrale, Tervuren, Belgique, Annales, Série in- $8^{\circ}$, Sciences géologiques $\mathrm{n}^{\circ}$ 90, $101 \mathrm{pp}$.

De Mulder, M., Pasteels, P., 1986. K-Ar geochronology of the Karisimbi volcano (Virunga, Rwanda-Zaire). Journal of African Earth Sciences 5, 575-579.

De Mulder, M., Hertogen, J., Deutsch, S., André, L., 1986. The role of crustal contamination in the potassic suite of the Karisimbi volcano (Virunga, African Rift Valley). Chemical Geology 57, 117-136.

Denaeyer, M.-E., 1954. Les anciens volcans sous-lacustres de la bordure nord du lac Kivu. Bulletin de la Société Belge de Géologie 63, 280-298. 
1085 Denaeyer, M.-E., 1960. Les laves de la bordure occidentale du fossé tectonique du Kivu, à

1086 l'ouest des Virunga. Bulletin de l'Académie Royale Sciences Outre-Mer de Belgique N. S.

$1087 \quad 6,1074-1085$.

1088 Denaeyer, M.-E., 1972. Les laves du fossé tectonique de l'Afrique Centrale (Kivu, Rwanda,

1089 Toro-Ankole). I. - Supplément au recueil d'analyses de 1965, II. - Magmatologie, III. -

1090 Magmatogenèse. Annales du Musée Royal de l'Afrique Centrale, Tervuren, Belgique,

1091 Série in- $8^{\circ}$, Sciences Géologiques $n^{\circ} 72,134$ pp.

1092 Denaeyer, M.-E., Schellinck, F., Coppez, A., 1965. Recueil d'analyses des laves du fossé

1093 tectonique de l'Afrique Centrale (Kivu, Rwanda, Toro-Ankole). Annales du Musée Royal

1094 Afrique Centrale, Tervuren, Belgique, Série in-8º, Sciences Géologiques n 49, 234 pp.

1095 De Paepe, P., Fernandez-Alonso, M., 1981. Contribution à la connaissance du volcanisme du

1096 Sud-Kivu : la région de Cyangugu-Bugarama (Rwanda). Musée Royal de l'Afrique

1097 Centrale, Tervuren, Belgique, Dépt. Géologie et Minéralogie, Rapport annuel 1980, 111-

$1098 \quad 126$.

1099 Dupuy, C., Liotard, J.M., Dostal, J., 1992. Zr/Hf fractionation in intraplate basaltic rocks:

1100 Carbonate metasomatism in the mantle source. Geochimica et Cosmichimica Acta 56,

$1101 \quad 2417-2423$.

1102 Ebinger, C.J., 1989a. Geometric and kinematic development of border faults and

1103 accommodation zones, Kivu-Rusizi rift, Africa. Tectonics 8, 117-133.

1104 Ebinger, C.J., 1989b. Tectonic development of the western branch of the East African rift

1105 system. Bulletin of the Geological Society of America 101, 885-903.

1106 Ebinger, C.J., Sleep, N.H., 1998. Cenozoic magmatism throughout east Africa resulting from

1107 impact of a single plume. Nature 395, 788-791.

1108 Ebinger, C.J., Bechtel, T.D., Forsyth, D.W., Bowin, C.O., 1989. Effective elastic plate

1109 thickness beneath the East African and Afar Plateaus and dynamic compensation of the

1110 uplifts., J. Geophys. Res. 94, 2883-2901.

1111 Ebinger, C.J., Jackson, J.A., Foster, A.N., Hayward, N.J., 1999. Extensional basin geometry

1112 and the elastic lithosphere. Phil. Trans. R. Soc. London A 357, 741-765.

1113 Eby, G.N., Lloyd, F.E., Woolley, A.R., 2009. Geochemistry and petrogenesis of the Fort

1114 Portal, Uganda, extrusive carbonatite. Lithos 113, 785-800.

1115 Evrard, P., Jones, L., 1963. Etude gravimétrique du graben de l'Afrique centrale. La région

1116 des volcans Nyiragongo et Nyamuragira. Mémoire de l'Académie royale des Sciences

1117 d'Outre-Mer de Belgique, Sciences et techniques 15(5), 1-71. 
1118

1119

1120

1121

1122

1123

1124

1125

1126

1127

1128

1129

1130

1131

1132

1133

1134

1135

1136

1137

1138

1139

1140

1141

1142

1143

1144

1145

1146

1147

1148

1149

1150

Felton, A.A., Russell, J.M., Cohen, A.S., Baker, M.E., Chesley, J.T., Lezzar, K.E., McGlue, M.M., Pigati, J.S., Quade, J., Stager, J.C., Tiercelin, J.J., 2007. Paleolimnological evidence for the onset and termination of glacial aridity from Lake Tanganyika, Tropical East Africa. Palaeogeography, Palaeoclimatology, Palaeoecology 252, 405-423.

Furman, T., 2007. Geochemistry of East African Rift basalts: An overview. Journal of African Earth Sciences 48, 147-160.

Furman, T., Graham, D., 1999. Erosion of lithospheric mantle beneath the East African Rift system: geochemical evidence from the Kivu volcanic province. Lithos 48, 237-262.

Furman, T., Bryce, J.G., Karson, J., Iotti A., 2004. East African Rift System (EARS) plume structure: Insights from Quaternary mafic lavas of Turkana, Kenya. Journal of Petrology 45, 1069-1088.

Furman, T, Kaleta, K.M., Bryce, J.G., Hanan, B.B., 2006. Tertiary mafic lavas of Turkana, Kenya: Constraints on East African plume structure and the occurrence of High- $\mu$ volcanism in Africa. Journal of Petrology 47, 1221-1244.

George, R.M., Rogers, N.W., 2002. Plume dynamics beneath the African Plate inferred from the geochemistry of the Tertiary basalts of southern Ethiopia. Contributions to Mineralogy and Petrology 144, 286-304.

George, R., Rogers, N., Kelley, S., 1998. Earliest magmatism in Ethiopia: evidence for two mantle plumes in one flood basalt province. Geology 26, 923-926.

Green, D.H., 1969. The origin of basaltic and nephelinitic magmas in the Earth's mantle. Tectonophysics 7, 409-432.

Guibert, P., 1977. Contribution à l'étude du volcanisme du sud Kivu (Zaïre). Archives des Sciences (Genève, Suisse) 30, 15-43.

Guibert, P., Delaloye, M., Hunziker, J., 1975. Contribution à l'étude géologique du volcan

Mikeno, Chaîne des Virunga (République du Zaïre) I: Données géochronologiques K/Ar.

II: Données isotopiques Rb/Sr. Comptes Rendus Séances Société Physique Histoire Naturelle 10, 57-66.

Haberyan, K.A., Hecky, R.E., 1987. The late Pleistocene and Holocene stratigraphy and paleolimnology of Lakes Kivu and Tanganyika. Palaeogeography, Palaeoclimatology, Palaeoecology 61, 169-197.

Hendrie, D.B., Kusznir, N.J., Morley, C.K., Ebinger, C.J., 1994. Cenozoic extension in northern Kenya: a quantitative model of rift basin development in the Turkana region. Tectonophysics 236, 409-438. 
1151 Hertogen, J., Vanlerberghe, L., Namegabe, M.R., 1985. Geochemical evolution of the

1152 Nyiragongo Volcano (Virunga, Western African Rift, Zaire). Bulletin Geological Society

1153 of Finland 57, 21-35.

1154 Higazy, R.A., 1954. Trace elements of volcanic ultrabasic potassic rocks of southwestern

1155 Uganda and adjoining part of the Belgian Congo. Bulletin Geological Society of America

$1156 \quad 65,39-70$.

1157 Holmes, A., 1965. Principles of physical geology. Ronald Press, New-York, $2^{\text {nd }}$ edition.

1158 Kampunzu, A., Pottier, Y., Vellutini, P.-J., 1979. A propos des produits volcaniques de

1159 Cibinda, région de Bukavu (Sud-Kivu, Zaïre). Annales de la Faculté des Sciences de

1160 Lubumbashi, Université nationale du Zaïre 2, 21-30.

1161 Kampunzu, A.B., Lubala, R.T., Caron, J.P.H., Vellutini, P.-J., 1983. Sur l'existence de deux

1162 cycles volcaniques précédant le volcanisme actuel des Virunga (Nord Kivu-Zaïre).

1163 Comptes Rendus de l'Académie des Sciences, Paris (France), Série II, 296, 839-844.

1164 Kampunzu, A.B., Lubala, R.T., Makutu, M.N., Caron, J.-P.H., Rocci, G., Vellutini, P.-J.,

1165 1985. Les complexes alcalins de la région interlacustre à l'Est du Zaïre et au Burundi: un

1166 exemple de massifs anorogéniques de relaxation. Journal of African Earth Sciences 3, 151-

$1167 \quad 167$.

1168 Kampunzu, A.B., Kramers, J.D., Makutu, M.N., 1998a. Rb-Sr whole rock ages of the Lueshe,

1169 Kirumba and Numbi igneous complexes (Kivu, Democratic Republic of Congo) and the

1170 break-up of the Rodinia supercontinent. Journal of African Earth Sciences 26, 29-36.

1171 Kampunzu, A.B., Bonhomme, M.G., Kanika, M., 1998b. Geochronology of volcanic rocks

1172 and evolution of the Cenozoic Western Branch of the East African Rift System. Journal of

1173 African Earth Sciences 26, 441-46.

1174 Kanika, M., Kampunzu, A.B., Caron, J.P.H., Vellutini, P.J., 1981. Données nouvelles sur le

1175 volcanisme de la Haute Ruzizi (Sud Kivu, Zaïre). Comptes Rendus de l'Académie des

1176 Sciences, Paris (France), série II, 292, 1277-1282.

1177 Kinzler, R.J., 1997. Melting of mantle peridotite at pressures approaching the spinel to garnet

1178 transition: application to mid-ocean ridge basalt petrogenesis. Journal of Geophysical

1179 Research 102, 853-874.

1180 Komorowski, J.-C., Tedesco, D., Kasereka, M., Allard, P., Papale, P., Vaselli, O., Durieux, J.,

1181 Baxter, P., Halbwachs, M., Akumbe, M., Baluku, B., Briole, P., Ciraba, M., Dupin, J.-C.,

1182 Etoy, O., Garcin, D., Hamaguchi, H., Houlie, N., Kavotha, K.S., Lemarchand, A.,

1183 Lockwood, J., Lukaya, N., Mavonga, G., de Michele, M., Mpore, S., Mukambilwa, K.,

1184 Munyololo, F., Newhall, C., Ruch, J., Yalire, M., Wafula, M., 2002. The January 2002 
1185 flank eruption of Nyiragongo volcano (Democratic Republic of Congo): chronology,

1186 evidence for a tectonic rift trigger, and impact of lava flows on the city of Goma. Acta

1187 Vulcanologica 14-15, 27-62.

1188 Kramm, U., Maravic, H.V., Morteani, G., 1997. Neodymium and Sr isotopic constraints on

1189 the petrogenetic relationships between carbonatites and cancrinite syenites from the Lueshe

$1190 \quad$ Alkaline Complex, east Zaire. Journal of African Earth Sciences 25, 55-76.

1191 Kusznir, N.J., Ziegler, P.A., 1992. The mechanics of continental extension and sedimentary

1192 basin formation: A simple-shear/pure-shear flexural cantilever model. Tectonophysics 215,

1193 117-131.

1194 Le Bas, M.J., 1981. Carbonatite magmas. Mineralogical Magazine 44, 133-140.

1195 Le Bas, M.J., 1987. Nephelinites and carbonatites. In Fitton, J.G., Upton, B.G.J. (Eds)

1196 Alkaline igneous rocks: Geological Society of London, Special Publication vol. 30, pp. 53-

119783.

1198 Ledent, D., Cahen, L., 1965. Quelques données géochronologiques nouvelles sur les minéraux

1199 des roches du Kivu méridional. Musée Royal de l'Afrique Centrale, Tervuren (Belgique),

$1200 \quad$ Rapport annuel 1964, 94-95.

1201 Louaradi, D., 1994. Etude isotopique (carbone, oxygène) et microthermométrique (inclusions

1202 fluides et vitreuses) des magmas alcalins et carbonatitiques du rift est africain et de la

1203 presqu'île de Kola. Ph. D. Thesis, University of Paris VII, France.

1204 Lubala, R.T., 1981. Etude géologique du massif de Biega (Kivu, Zaïre). Structure,

1205 géochronologie et signification géotectonique. Ph. D. Thesis, Univ. Zaïre, Lubumbashi,

$1206308 \mathrm{pp}$.

1207 Lubala, R.T., Kampunzu, A.R., Caron, J.P.H., Vellutini, P.J., 1982. Sur la nature et la

1208 signification possible des basaltes de la Lugulu au Sud-Kivu (Zaïre). Comptes Rendus de

1209 l'Académie des Sciences, Paris, Série II, 294, 325-328.

1210 Lubala, R.T., Kampunzu, A.R., Caron, J.P.H., Vellutini, P.J., 1984. Minéralogie des basaltes

1211 saturés tertiaires du Kahuzi-Biéga (Rift du Kivu, Zaïre). Annales de la Société Géologique 1212 de Belgique 107, 125-134.

1213 Lubala, R.T., Kampunzu, A.R., Caron, J.P.H., Vellutini, P.J., 1987. Petrology and

1214 geodynamic significance of the Tertiary alkaline lavas from the Kahuzi-Biega region,

1215 Western rift, Kivu, Zaire. In: Bowden, P. and Kinnaird, J. (Eds) African geology reviews,

1216 Geological journal 22, pp. 515-535. 
1217 Mahood G. and Drake R. E. 1982. K-Ar dating young rhyolite rocks : a case study of the

1218 Sierra La Primavera, Jalisco, Mexico, Geological Society of America Bulletin 93, 1232-

$1219 \quad 1241$.

1220 Marcelot, G., Dupuy, C., Dostal, J., Rançon, J.P., Pouclet, A., 1989. Geochemistry of mafic

1221 volcanic rocks from the Lake Kivu (Zaire and Rwanda) section of the western branch of

1222 the African rift. Journal of Volcanology and Geothermal Research 39, 73-88.

1223 Meyer, A., 1953. Notes vulcanologiques. Les basaltes du Kivu méridional. Mémoires du

1224 Service géologique du Congo belge et du Ruanda Urundi 2, 25-52.

1225 Meyer, A., Burette, H., 1957. Nouveaux phénomènes volcaniques au sud-Kivu. Bulletin du

1226 Service Géologique du Congo belge 7 (4), 1-15.

1227 Mitchell, R.H., Bell, K., 1976. Rare Earth element geochemistry of potassic lavas from the

1228 Birunga and Toro-Ankole regions of Uganda, Africa. Contributions to Mineralogy and

1229 Petrology 58, 293-303.

1230 Ongendangenda, T., 1992. Le magmatisme potassique du volcan Visoke (Chaîne des Virunga,

1231 Rift Est Africain) : aspects volcanologiques, pétrologiques et géochimiques. $\mathrm{Ph}$. D. Thesis,

1232 University of Aix-Marseille III, France, 304 pp.

1233 Pasteels, P., Boven, A., 1989. Excès d'argon dans les basaltes de la zone volcanique d'Idjwi

1234 sud (Kivu, Zaïre). Musée Royal de l'Afrique Centrale, Tervuren (Belgique), Département

1235 de Géologie et Minéralogie, Rapport annuel 1987-1988, 101-107.

1236 Pasteels, P., Villeneuve, M., De Paepe, P., Klerkx, J., 1989. Timing of the volcanism of the

1237 southern Kivu province: implications for the evolution of the western branch of the East

1238 African Rift system. Earth and Planetary Science Letters 94, 353-363.

1239 Platz, T., Foley, S.F., André, L., 2004. Low-pressure fractionation of the Nyiragongo volcanic

1240 rocks, Virunga Province, D.R. Congo. Journal of Volcanology and Geothermal Research

$1241 \quad 136,269-295$.

1242 Pottier, Y., 1978. Première éruption historique du Nyiragongo et manifestations adventives

1243 simultanées du volcan Nyamulagira (Chaîne des Virunga - Kivu - Zaïre : Déc. 76 - Juin

1244 77). Musée Royal de l'Afrique Centrale, Tervuren (Belgique), Département de Géologie et

1245 Minéralogie, Rapport annuel 1977, 157-175.

1246 Pouclet, A., 1973. Contribution à la connaissance du Volcan Nyiragongo (Rift ouest-africain).

1247 Les éruptions intra-cratérales de juillet 1971 à avril 1972. Bulletin Volcanologique 37-1,

1248 37-72. 
1249 Pouclet, A., 1975. Histoire des grands lacs de l'Afrique Centrale. Mise au point des connaissances actuelles. Revue de Géographie physique et de Géologie dynamique (2) 17, 475-482.

1252

Pouclet, A. 1976. Volcanologie du rift de l'Afrique Centrale. Le Nyamuragira dans les Virunga. Essai de magmatologie du rift. Ph. D. Thesis, University of Paris-Sud, France, $610 \mathrm{pp}$.

Pouclet, A., 1977. Contribution à l'étude structurale de l'aire volcanique des Virunga, rift de l'Afrique Centrale. Revue de Géographie physique et de Géologie dynamique (2) 19, 115 124.

Pouclet, A., 1978. Les communications entre les grands lacs de l'Afrique Centrale. Implications sur la structure du rift occidental. Musée Royal de l'Afrique Centrale, Tervuren (Belgique), Département de Géologie et Minéralogie, Rapport annuel 1977, 145155.

Pouclet, A., 1980. Contribution à la systématique des laves alcalines, les laves du rift de

1264 Pouclet, A., Villeneuve, M., 1972. L'éruption du Rugarama (mars-mai 1971) au volcan

1265 Nyamuragira (Rép. Zaïre). Bulletin Volcanologique 36-1, 200-221.

1266 Pouclet, A., Ménot, R.P., Piboule, M., 1981. Classement par l'analyse factorielle discriminante des laves du rift de l'Afrique Centrale (Zaïre, Rwanda, Uganda). Comptes Rendus de l'Académie des Sciences, Paris (France) 292 (série II), 679-684.

Pouclet, A., Ménot, R.P., Piboule, M., 1983. Le magmatisme alcalin potassique de l'aire volcanique des Virunga (Rift occidental de l'Afrique de l'Est). Une approche statistique dans la recherche des filiations magmatiques et des mécanismes de différenciation. Bulletin de Minéralogie 106, 607-622.

1273 Pouclet, A., Ménot, R.P., Piboule, M., 1984. Différenciation des laves de l'Afrique Centrale

1274 (Rift Ouest). Contribution de l'analyse statistique multivariée. Neues Jahrbuch für

1275 Mineralogie Abhandlungen 149, 283-308.

1276 Rançon, J.P., Demange, J., 1983. Reconnaissance géothermique de la République du Rwanda.

1277 Bureau de Recherches Géologiques et Minières, rapport 83 SGN 192GTH, 130 pp.

1278 Rogers, N.W., De Mulder, M., Hawkesworth, C.J., 1992. An enriched mantle source for

1279 potassic basanites: evidence from Karisimbi volcano, Virunga volcanic province, Rwanda.

1280 Contribution to Mineralogy and Petrology 111, 543-556.

1281 Rogers, N.W., James, D., Kelley, S.P., De Mulder, M., 1998. The generation of potassic lavas 1282 from the Eastern Virunga Province, Rwanda. J. Petrology 39, 1223-1247. 
1283 Rogers, N.W., Macdonald, R., Fitton, J.G., George, R., Smith, M., Barreiro, B., 2000. Two

1284 mantle plumes beneath the East African Rift system: $\mathrm{Sr}, \mathrm{Nd}$ and $\mathrm{Pb}$ isotope evidence from

1285 Kenya rift basalts. Earth Planet. Sci. Lett. 176, 387-400.

1286 Rollinson, H., 1993. Using geochemical data: Evaluation, presentation, interpretation.

1287 Longman Group UK Limited, 352 pp.

1288 Rosenthal, A., Foley, S.F., Pearson, D.G., Nowell, G.M., Tappe, S., 2009. Petrogenesis of

1289 strongly alkaline primitive volcanic rocks at the propagating tip of the western branch of

1290 the East African Rift. Earth and Planetary Science Letters 284, 236-248.

1291 Rooney, T.O., 2010. Geochemical evidence of lithospheric thinning in the southern Main

1292 Ethiopia Rift. Lithos 117, 33-48.

1293 Rudnick, R.L., McDonough, W.F., Chappell, B.W., 1993. Carbonatite metasomatism in the

1294 northern Tanzanian mantle: petrographic and geochemical characteristics. Earth and

1295 Planetary Science Letters 114, 463-475.

1296 Sahama, Th.G., 1973. Evolution of the Nyiragongo magma. Journal of Petrology 14, 33-48.

1297 Sahama, Th.G., 1978. The Nyiragongo main cone. Musée Royal de l'Afrique Centrale,

1298 Tervuren (Belgique), Annales, Sciences géologiques 81, 88pp.

1299 Steiger, R.H., Jäger, E., 1977. Subcomission of geochronology: convention on the use of

1300 decay constants in geo- and cosmochronology. Earth and Planetary Science Letters 36,

$1301 \quad 359-362$.

1302 Stracke, A., Hofmann, A.W., Hart, S.R., 2005. FOZO, HIMU, and the rest of the mantle zoo.

1303 Geochemistry Geophysics Geosystem 6 (5), 1-20.

1304 Sun, S.S., McDonough, W.F., 1989. Chemical and isotopic systematics of oceanic basalts:

1305 Implications for mantle composition and processes. In: Saunders, A.D. and Norry, M.J.

1306 (Eds), Magmatism in the ocean basins: Geological Society of London, Special Publication

1307 vol. 42, pp. 313-345.

1308 Tack, L., De Paepe, P., 1983. Le volcanisme du Sud-Kivu dans le nord de la plaine de la

1309 Rusizi au Burundi et ses relations avec les formations géologiques avoisinantes. Musée

1310 Royal de 1'Afrique Centrale, Tervuren, Belgique, Département de Géologie et Minéralogie,

1311 Rapport annuel 1981-1982, 137-145.

1312 Tack, L., Wingate, M.T.D., De Waele, B., Meert, J., Belousova, E., Griffin, B., Tahon, A.,

1313 Fernandez-Alonso, M., 2010. The 1375 Ma "Kibaran event" in Central Africa: Prominent

1314 emplacement of bimodal magmatism under extensional regime. Precambrian Research

$1315180,63-84$. 
1316 Tanaka, K., 1983. Seismicity and focal mechanism of the volcanic earthquakes in the Virunga

1317 Volcanic Region. In: Hamagushi, H. (Ed.), Volcanoes Nyiragongo and Nyamuragira:

1318 Geophysical Aspects. Tohoku University, Sendai, Japan, pp. 19-28.

1319 Thornton, C.P., Tuttle, O.F., 1960. Chemistry of igneous rocks. I, differentiation index.

1320 American Journal of Sciences 253, 664-684.

1321 Toscani, L., Capedri, S., Oddone, M., 1990. New chemical and petrographic data of some

1322 undersaturated lavas from Nyiragongo and Mikeno (Virunga-Western African Rift -

1323 Zaire). Neues Jahrbuch Miner. Abh. 161, 287-302.

1324 Van Overbeke, A.-C., Demaiffe, D., Verkaeren, J., 1996. The syenite-carbonatite complex of

1325 Lueshe (N-E Zaïre): petrography, geochemistry and Rb-Sr chronology. In: Demaiffe, D.

1326 (Ed.), Petrology and Geochemistry of magmatic suites of rocks in the continental and

1327 oceanic crusts. Université libre de Bruxelles and Royal Museum for Central Africa

1328 (Tervuren, Belgique) pp. 355-370.

1329 Verhaeghe, M.A.P., 1958. Eruption du volcan Mugogo au Kivu. Comptes Rendus de

1330 l'Académie des Sciences, Paris (France), 246, 2917-2920.

1331 Villeneuve, M., 1978. Les centres d'émissions volcaniques du rift africain au sud du lac Kivu

1332 (République du Zaïre). Revue de Géographie physique et de Géologie dynamique (2) 20,

$1333 \quad 323-334$.

1334 Villeneuve, M., 1987. Géologie du synclinal de l'Itombwe (Zaïre oriental) et le problème de

1335 l'existence d'un sillon plissé Pan-africain. Journal of African Earth Sciences 6, 869-880.

1336 Villeneuve, M., Chorowicz, J., 2004. Les sillons plissés du Burundien supérieur dans la

1337 chaîne Kibarienne d'Afrique centrale. Comptes rendus Géoscience 336, 807-814.

1338 Vollmer, R., Norry, M.J., 1983. Possible origin of K-rich volcanic rocks from Virunga, East

1339 Africa, by metasomatism of continental crust material: $\mathrm{Pb}, \mathrm{Nd}$ and $\mathrm{Sr}$ isotope evidence.

1340 Earth and Planetary Science Letters 64, 374-386.

1341 Vollmer, R., Nixon, P.H., Condliffe, E., 1985. Petrology and geochemistry of a U and Th

1342 enriched nephelinite from Mt. Nyiragongo, Zaire: Its bearing on ancient mantle

1343 metasomatism. Bulletin Geological Society of Finland 57, 37-46.

1344 Walter, M.J., 1998. Melting of garnet peridotite and the origin of komatiite and depleted

1345 lithosphere. Journal of Petrology 39, 29-60.

1346 Williams, R.W., Gill, J.B., 1992. Th isotope and U-series disequilibria in some alkali basalts.

1347 Geophysical Research Letters 19, 139-142.

1348 Wong, H.-K., Von Herzen, R.P., 1974. A geophysical study of Lake Kivu, East Africa.

1349 Geophysical Journal of the Royal Astronomy Society 37, 371-389. 
1350 Yoder, H.S., Tilley, C.E., 1962. Origin of basalt magmas: an experimental study of natural

1351 and synthetic rock systems. Journal of Petrology 3, 342-532.

\section{Caption}

1354

Fig. 1 - Tectonic pattern of the western branch of the Eastern Africa rift system in the Lake

Fig. 4 - Map of strombolian cones of the Tchibinda Volcanic Chain (new map) and location

Fig. 2 - Tectonic map of the Lake Kivu and altitude of rift steps in metres. This new map is drawn after the bathymetric map and the geophysical data of Degens et al. (1973) and Wong and Von Herzen (1974), which were acquired during two cruises of the Woods Hole Oceanographic Institution in 1971 and 1972. The sub-water volcanoes were discovered using echo sounder and magnetometer records. A-B and C-C, interpreted cross-sections in the northern and southern basins, respectively. Sub-lacustrine volcanoes of the northern lake side are linked to the Late Pleistocene activity of Virunga during the high level stage (Pouclet, 1975). The South-Idjwi sub-lacustrine volcanoes are much older (Miocene), see section 4.2. Mineral hot springs deposited thick travertine terraces or sinters in the Holocene. The up-lifting points are localized using topographical data. They mark the westward and eastward tilting of the horst steps, in the west side and the east side, respectively.

Fig. 3 - Geological sketch map of the Mount Kahuzi area showing the birth of tholeiitic Lugulu flows (new map). The MM2 basaltic lava is dated at $8.19 \pm 0.40 \mathrm{Ma}$ (new dating, Table 2). This lava flow westward poured out during the doming stage of the Kivu Rift, before the rift valley formation. Igneous intrusions are dated to Neoproterozoic and consist of quartz-porphyry microgranite in Mount Kahuzi and of acmite-riebeckite-bearing granites and syenites in the other areas (ref. in the text). of the analysed lavas. The CRSN "Centre de Recherches en Sciences Naturelles", formerly IRSAC "Institut pour la Recherche Scientifique en Afrique Centrale” is located at Lwiro. 
Sample numbers refer to analysed rocks (Table 1). Full dots are dated samples: TB4 $=1.9$ Ma ; MM1 = 1.7 Ma ; KT1 = 1.6 Ma (Table 4); MM2 = 8.19 Ma (Table 2).

Fig. 5 - Map of the Virunga Volcanic area locating the Plio-Quaternary volcanic activities after Pouclet (1977) completed with the recent volcanic centres. Main edifices: Nyamuragira (N), Nyiragongo (Ny) and its two "elder brothers" Shaheru (Sh) and Baruta (B), Mikeno (M), Karisimbi (K) and its older craters Branca (Br) and Muntango (Mt), Visoke (V), Sabinyo (S), Gahinga (G), and Muhavura (Mh). Lithology of the surrounding substratum is specified. Red dots, flank or parasitic cones; red diamonds, historical parasitic activities.

Fig. 6 - Map of the Bishusha-Tongo area (new map). Outcrops of the Miocene lavas.

Fig. 7 - Qtz-Ab+Or-Hy-Ol-Ne combined ternary diagrams of the Kivu basaltic lavas. Data Altitudes of the Tongo uplifted Pleistocene terraces in metres. after Meyer (1953), Meyer and Burette (1957), Denaeyer et al. (1965), Denaeyer (1972), Pouclet (1976), Guibert (1977), Villeneuve (1978), Kampunzu et al. (1979, 1983, 1998b), Bellon and Pouclet (1980), De Paepe and Fernandez-Alonso (1981), Kanika et al. (1981), Lubala (1981), Lubala et al. (1982, 1984, 1987), Tack and De Paepe (1983), Auchapt (1987), Auchapt et al. (1987), Marcelot et al. (1989), Pasteels et al. (1989), Furman and Graham (1999), and new analyses (Table 1). Normative nomenclature: T, tholeiite (Qtz); Ol-T, olivine-tholeiite ( $\mathrm{Ol}$ and $>15 \% \mathrm{Hy}$ ); Ol-B, olivine basalt ( $\mathrm{Ol}$ and < 15\% Hy); Alk-B,

Fig. 8 - Primitive Mantle normalized incompatible element diagram of the South-Kivu tholeiitic and alkali basaltic lavas. Tholeiitic and basaltic areas drawn after the analytical

1413 Fig. 9 - $\mathrm{Yb}$ vs. La/Yb and La/Sm vs. Sm/Yb diagrams for determining the enrichment of the 1414 source and the partial melting degrees of mantle source. (A) The $\mathrm{Yb}$ vs. La/Yb diagram 1415 indicates an increase of partial melting, from basanites to tholeiites, and/or varying 1416 enrichment of sources compared with the average OIB-type source. (B) Batch melting of 
the enriched source $\mathrm{C} 1$ and of the less enriched source $\mathrm{C} 2$. Melt curves are drawn for spinel-lherzolite, garnet-lherzolite and a 50:50 mixture of spinel- and garnet-lherzolite. Modal compositions of spinel-lherzolite (olivine 53\%, OPX 27\%, CPX 17\%, spinel 3\%) and garnet-lherzolite (olivine 60\%, OPX 20\%, CPX 10\%, garnet 10\%) are after Kinzler (1997) and Walter (1998). Mineral/melt partition coefficients for basaltic liquids are after compilation of Rollinson (1993). Tholeiites may have resulted from ca. 10\% of partial melting of spinel-lherzolite from a moderately enriched source. Basaltic and alkaline lavas resulted from lower degrees of partial melting (10\% to $2 \%$ ) of a spinel- and garnetlherzolite mixture of varying amount of spinel and garnet. McDonough (1989).

Fig. $10-\mathrm{Nb} / \mathrm{Yb}$ vs. Th/Yb diagram to test crustal contamination. Same symbols as for Figure (1989). All the lavas plot in the mantle array, precluding any perceptible crustal contamination.

Fig. 11 - (A) La vs. Yb, (B) Ba vs. La, and (C) Nb vs. Zr covariation diagrams. Same symbols as for Figure 9. Tsh, Tshibinda Volcanic Chain; Lem, Leymera; PM, partial melting curves; FC, fractional crystallization; trend \# 1, low-Yb, high-La, high-Ba, and low-Zr curves evolving from basanites to olivine basalts (enriched source); trend \# 2, low-La, low$\mathrm{Ba}$, and high- $\mathrm{Zr}$ curves characterizing the tholeiites and some olivine basalts (less enriched

1447 Fig. 12 - Primitive Mantle normalized incompatible element diagram of North-Idjwi and Pre-

1448 Virunga lavas. These sodic-rich lavas are more fractionated than the basaltic lavas of 1449 South-Kivu. Normalizing values after Sun and McDonough (1989). 
1451 Fig. 13 - Primitive Mantle normalized incompatible element diagram of (A) Nyamuragira 1452 lavas compared with South-Kivu lavas, (B) the other basanitic volcanoes of Virunga, (C)

1453 Nyiragongo lavas compared with Nyamuragira lavas, and (D) the other leucite-nephelinitic 1454 volcanoes of Virunga.

Fig. 14 - La/Sm vs. Sm/Yb diagram of Virunga mafic lavas. Batch melting of the enriched source C1. Melt curves as in Figure 9. The Virunga magma can be originated from a garnet- and a few spinel-bearing lherzolite source. The degree of partial melting is higher

Fig. 15 - Zr/Hf vs. Hf diagram of mafic lavas of Virunga. Hf and $\mathrm{Zr} / \mathrm{Hf}$ chondritic values of for the basanite magma than for the nephelinite magma. Same symbols as for Figure 13. K-basanites of Nyamuragira, Karisimbi, and eastern volcanoes are consistent with partial melting of common mantle. High $\mathrm{Zr} / \mathrm{Hf}$ ratios in the Nyiragongo lavas imply the contribution of Hf-poor carbonatite component, as shown by the Namibian nephelinitecarbonatite association. Same symbols as for Figure 13.

Fig. 16 - Inferred location of the metasomatized and carbonated mantle in the sub-lithospheric mantle of the Virunga area, after geochemical signatures of the Plio-Quaternary volcanoes. Normal mantle is suspected below the Miocene volcanic area. Small red stars are the eruptive centers of the most primitive lavas unrelated to the magma chambers of the large volcanoes (St, Suri-Turunga; Mv, Muvo; Nh, Nahimbi; Rm,

Fig. 18 - Histogram of all the geochronological data. Volcanic activity initiated south of the

Fig. 17 - Location of the new geochronological data in the Lake Kivu and South-Kivu volcanic area. Data in Table 2. future Lake Kivu trough, at $21 \mathrm{Ma}$, with alkaline sodic nephelinite. It evolved to sodic basanite in the Pre-Virunga region, between 13 and 9 Ma. A distinct tholeiitic volcanism appeared in the South-Kivu region at $11 \mathrm{Ma}$, and is progressively replaced by alkaline activity until the last pulse in the Tshibinda Chain ca. 1.7 Ma. The oldest activity of the Virunga area is dated at 2.6 Ma in the Mikeno volcano. 
1486 Fig. 19 - Geographical distribution of the volcanic activity

1487 (A) Data from 21 to 9 Ma. The initial activity is nephelinitic and is limited to the middle part of the future Lake Kivu. In the Virunga area, the rift valley did not exist during the PreVirunga activity. In the South-Kivu area, the activity is tholeiitic and located along N-S fractures of the future rift axis. Late Neoproterozoic alkaline intrusions: L, Lueshe; K, Kirumba; B, Bishusha; F, Fumbwe; N, Numbi; Kz, Kahuzi; Bg, Biega. The layout of these intrusions suggests a structural weakness line.

(B) Data from $9 \mathrm{Ma}$ to Present. In the Virunga area, activity began ca. 2.6 Ma in the middle of the oblique rift segment. In South-Kivu, activity extended to the whole area along N-S and NNE-SSW fractures and changed from tholeiitic to alkaline between 8.5 and 5.9 Ma. Activity occurred to the south-west along the NE-SW fractures of Mwenga, ca. 5.8 to 2.6

Table 1 - New analyses and analyses of dated samples from Marcelot et al. (1989). Alk-B, alkali basalt; Ol-B, olivine basalt; Bs, basanite; Na-Bs, sodic basanite; Benm, benmoreite; $\mathrm{H}$, hawaiite; Mug, mugearite; Neph, nephelinite; $\mathrm{T}$, tholeiite. Analytical method and laboratory: $\mathrm{H}=$ atomic absorption spectrometry (AA) for the major elements and instrumental neutron activation (INAA) and X-ray fluorescence (XRF) for the minor elements at the University of Halifax (Canada); $\mathrm{O}=$ inductively-coupled plasma spectrometry (ICP-OES) at the analytical laboratory of the University and CNRS of Orléans (France); P = atomic absorption spectrometry at the Department of PetrographyVolcanology of the University of Paris-Sud; T = XRF at the Musée Royal de l'Afrique Centrale of Tervuren (Belgique). Ages are from Tables 2 and 4.

Table 2 - New K-Ar geochronological analyses. Most of potassium-argon ages were measured at the "Université de Bretagne Occidentale" in Brest (France) on grains of whole-rock, 0.3 to $0.15 \mathrm{~mm}$ in size, obtained after crushing and subsequent sieving of the solid samples. One aliquot of grains was powdered in an agate grinder for chemical attack of around $0.1 \mathrm{~g}$ of powder by $4 \mathrm{cc}$ of hydrofluoric acid, before its analysis of $\mathrm{K}$ content by AAS (Atomic Absorption Spectrometry). A second aliquot of grains was reserved for argon analysis. About $0.7 \mathrm{~g}$ to $0.8 \mathrm{~g}$ of grains were heated and fused under vacuum in a molybdenum crucible, using a high frequency generator. Released gases during this step 
1519 were cleaned successively on three quartz traps containing titanium sponge when their

1520 temperature was decreasing from $800^{\circ} \mathrm{C}$ to the ambient one, during 10 minutes; at the final

1521 step the remaining gas fraction was ultra-purified using a Al-Zr SAES getter. Isotopic

1522 compositions of argon and concentrations of radiogenic argon ${ }^{40} \mathrm{Ar}^{*}$ were measured in a

1523 stainless steel mass spectrometer with a $180^{\circ}$ geometry and a permanent magnetic field.

1524 Isotopic dilution was realized during the fusion step, using precise concentrations of ${ }^{38} \mathrm{Ar}$

1525 buried as ions in aluminium targets (Bellon et al., 1981). Ages are calculated using Steiger

1526 and Jäger's (1977) constants and errors, following the equation of Mahood and Drake

1527 (1982).

1528

1529 Table 3 - Trace element composition of the South-Kivu magma sources according to Auchapt $1530 \quad$ (1987).

1531

1532 Table 4 - K-Ar geochronological data for the Lake Kivu area lavas (Western Branch of the

1533 East African Rift) excluding the post-1 Ma lavas. References: 1, Bagdasaryan et al. (1973);

1534 2, Guibert et al. (1975); 3, Bellon and Pouclet (1980); 4, Pasteels and Boven (1989); 5,

1535 Pasteels et al. (1989); 6, Kampunzu et al. (1998b); 7, this work. 


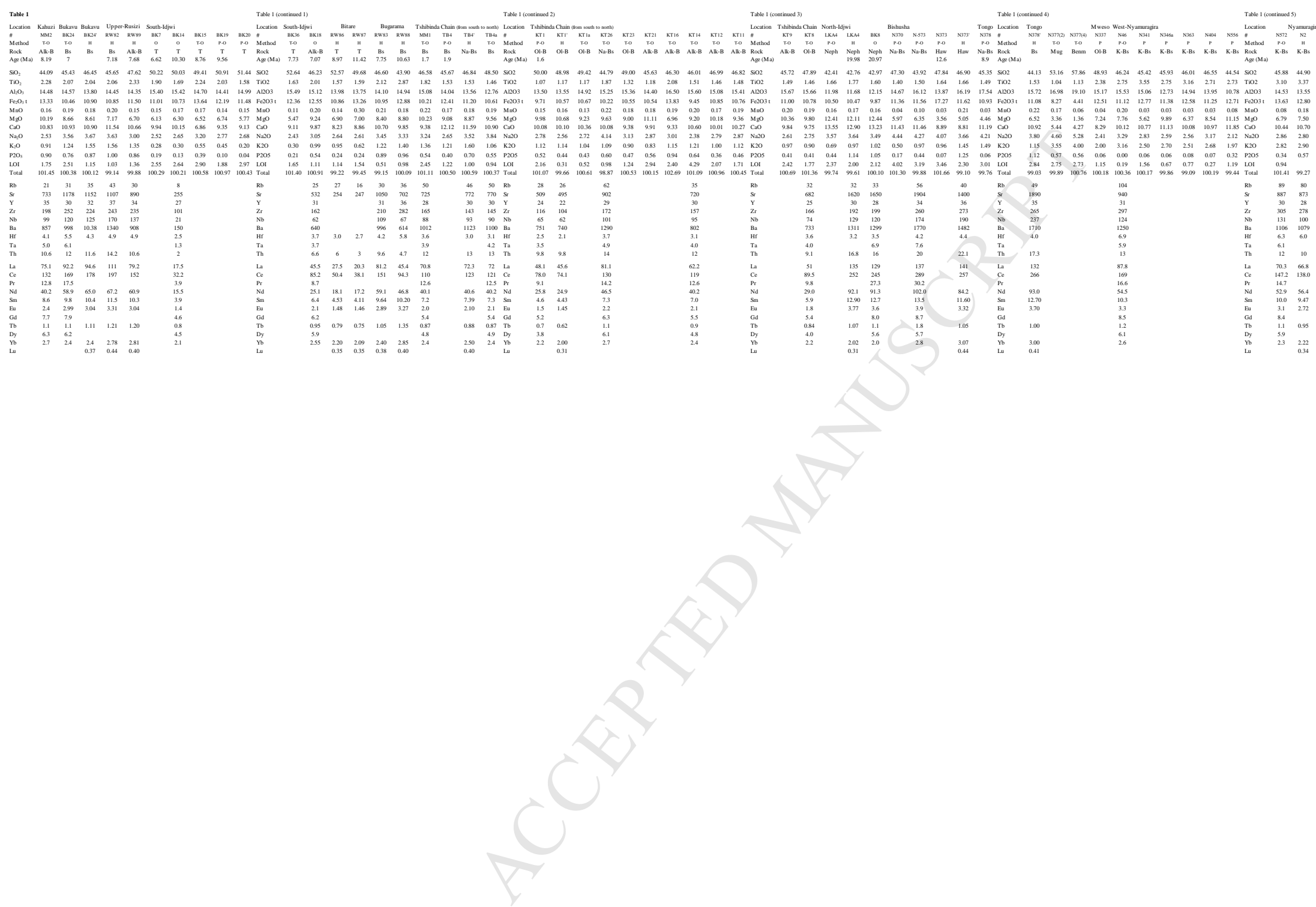


Table 2 Whole rock K-Ar age dating

\begin{tabular}{|c|c|c|c|c|c|c|c|}
\hline Location & $\begin{array}{c}\text { Sample } \\
\#\end{array}$ & Rock type & $\begin{array}{c}\text { Fused } \\
\text { mass (g) }\end{array}$ & $\begin{array}{c}\mathrm{K}_{2} \mathrm{O} \\
(\mathrm{wt} \%)\end{array}$ & $\begin{array}{c}{ }^{40} \mathrm{Ar}^{*} \\
\left(10^{-7} \mathrm{cc} / \mathrm{g}\right)\end{array}$ & ${ }^{40} \mathrm{Ar} * /{ }^{40} \mathrm{Ar}_{\mathrm{t}}$ & $\begin{array}{c}\text { Age (Ma) } \\
\pm 1 \sigma\end{array}$ \\
\hline North-Idjwi & BK8 & Nephelinite & $\begin{array}{l}0.7137 \\
0.7094\end{array}$ & $\begin{array}{l}1.46 \\
1.46\end{array}$ & $\begin{array}{c}9.82 \\
10.04\end{array}$ & $\begin{array}{r}42.6 \\
57.9 \\
\text { Mean age }\end{array}$ & $\begin{array}{l}20.74 \pm 0.56 \\
21.21 \pm 0.52 \\
20.97 \pm 0.56\end{array}$ \\
\hline North-Idjwi & LKA4 & Nephelinite & 1.0160 & 1.27 & 8.23 & 50.7 & $19.98 \pm 1.00$ \\
\hline Bitare & RW87 & Tholeiite & 1.0108 & 0.55 & 2.03 & 27.0 & $11.42 \pm 0.57$ \\
\hline Bugarama & RW88 & Basanite & 1.0023 & 1.25 & 4.29 & 52.7 & $10.63 \pm 0.53$ \\
\hline South-Idjwi & BK14 & Tholeiite & 0.7007 & 0.43 & 1.43 & 28.4 & $10.30 \pm 0.35$ \\
\hline South-Idjwi & BK19 & Tholeiite & 1.0049 & 0.68 & 2.10 & 27.8 & $9.56 \pm 0.48$ \\
\hline Bitare & RW86 & Tholeiite & 1.0009 & 0.90 & 2.61 & 37.3 & $8.97 \pm 0.45$ \\
\hline South-Idjwi & BK15 & Tholeiite & 1.0145 & 0.66 & 1.87 & 19.3 & $8.76 \pm 0.44$ \\
\hline Kahuzi & MM2 & Alkaline basalt & $\begin{array}{l}1.0171 \\
0.7039\end{array}$ & $\begin{array}{l}0.87 \\
0.87\end{array}$ & $\begin{array}{l}2.23 \\
2.38\end{array}$ & $\begin{array}{r}41.1 \\
38.6 \\
\text { Mean age }\end{array}$ & $\begin{array}{l}7.92 \pm 0.21 \\
8.47 \pm 0.24 \\
8.19 \pm 0.40\end{array}$ \\
\hline Upper Ruzizi & RW90 & Olivine basalt & 1.0130 & 0.76 & 1.99 & 26.6 & $8.10 \pm 0.40$ \\
\hline Bugarama & RW83 & Basanite & 1.0115 & 1.15 & 2.88 & 39.8 & $7.75 \pm 0.39$ \\
\hline South-Idjwi & BK36 & Tholeiite & 0.7154 & 0.38 & 0.95 & 16.5 & $7.73 \pm 0.30$ \\
\hline Upper Ruzizi & RW89 & Alkaline basalt & 1.0022 & 1.20 & 2.98 & 32.7 & $7.68 \pm 0.38$ \\
\hline Bukavu & RW82 & Basanite & 1.0072 & 1.56 & 3.62 & 44.3 & $7.18 \pm 0.36$ \\
\hline South-Idjwi & BK18 & Alkaline basalt & 0.7101 & 1.00 & 2.28 & 10.8 & $7.07 \pm 0.51$ \\
\hline South-Idjwi & BK7 & Tholeiite & 0.7007 & 0.43 & 0.92 & 9.7 & $6.62 \pm 0.66$ \\
\hline Bukavu & RW81 & Basanite & 1.0086 & 1.45 & 2.96 & 43.0 & $6.33 \pm 0.32$ \\
\hline
\end{tabular}


Table 3 Trace element composition of the South-Kivu magma sources

$\begin{array}{lcc} & \text { C1 } & \text { C2 } \\ \mathrm{Sr} & 51 & 45 \\ \mathrm{Y} & 7.5 & 7.2 \\ \mathrm{Zr} & 19 & 25 \\ \mathrm{Nb} & 3.3 & 3.3 \\ \mathrm{Ba} & 38 & 26 \\ \mathrm{Hf} & 0.48 & 0.62 \\ \mathrm{Th} & 0.52 & 0.26 \\ & & \\ \mathrm{La} & 3.80 & 2.33 \\ \mathrm{Ce} & 7.10 & 5.05 \\ \mathrm{Nd} & 3.10 & 2.90 \\ \mathrm{Sm} & 0.84 & 0.80 \\ \mathrm{Eu} & 0.30 & 0.30 \\ \mathrm{~Tb} & 0.16 & 0.16 \\ \mathrm{Yb} & 0.67 & 0.66\end{array}$


Table 4 K-Ar geochronological data for the Lake Kivu area lavas

\begin{tabular}{|c|c|c|c|c|c|c|c|c|c|}
\hline Location & Sample \# & Rock type & Age & Ref. & Location & Sample \# & Rock type & Age & Ref. \\
\hline North-Idjwi & BK8 & Nephelinite & $20.97 \pm 0.56$ & 7 & Burundi & 19 & Tholeiite & $7.6 \pm 0.5$ & 5 \\
\hline North-Idjwi & LKA4 & Nephelinite & $19.98 \pm 1.00$ & 7 & South-Idjwi & 18 & Tholeiite & $7.6 \pm 0.3$ & 5 \\
\hline Bishusha & N373 & Hawaiite & $12.6 \pm 0.7$ & 3 & West-Bukavu & 2 & Basanite & $7.3 \pm 0.3$ & \\
\hline Tongo & TRK4 & Benmoreite & $11.8 \pm 0.8$ & 6 & Upper-Rusizi & RW82 & Basanite & $7.18 \pm 0.36$ & 7 \\
\hline Bitare & RW87 & Tholeiite & $11.42 \pm 0.57$ & 7 & South-Idjwi & BK18 & Alk-Basalt & $7.07 \pm 0.51$ & \\
\hline Bishusha & TR44 & Ol-Tholeiite & $11.0 \pm 0.5$ & 6 & Bukavu & BK24 & Basanite & $7.00 \pm 0.35$ & 3 \\
\hline Bishusha & TR50 & Ol-Tholeiite & $10.8 \pm 1.7$ & 6 & Kahuzi & AK486 & Ol-Tholeiite & $6.90 \pm 0.35$ & 5 \\
\hline Bishusha & TR5 & Ol-Basalt & $10.7 \pm 0.7$ & 6 & Upper-Rusizi & 11 & Alk-Basalt & $6.7 \pm 0.5$ & \\
\hline Bugarama & RW88 & Basanite & $10.63 \pm 0.53$ & 7 & South-Idjwi & BK7 & Tholeiite & $6.62 \pm 0.66$ & 7 \\
\hline South-Idjwi & BK14 & Tholeiite & $10.30 \pm 0.35$ & 7 & Upper-Rusizi & 12 & Hawaiite & $6.45 \pm 0.90$ & \\
\hline Tongo & TRK2a & Benmoreite & $10.2 \pm 0.7$ & 6 & Upper-Rusizi & RW81 & Basanite & $6.33 \pm 0.32$ & \\
\hline Lower-Rusizi & 27 & Tholeiite & $10.0 \pm 2.0$ & 5 & Upper-Rusizi & 10 & Hawaiite & $6.2 \pm 0.3$ & 5 \\
\hline Bugarama & 17 & Tholeiite & $10.0 \pm 0.6$ & 5 & Upper-Rusizi & 22 & Benmoreite & $6.14 \pm 0.30$ & 5 \\
\hline Bishusha & TR1b & Hawaiite & $9.9 \pm 1.2$ & 6 & West-Bugarama & 9 & Hawaiite & $6.06 \pm 0.27$ & \\
\hline Bishusha & TR12 & Basanite & $9.7 \pm 1.3$ & 6 & Bugarama & 13 & Hawaiite & $5.9 \pm 0.5$ & 5 \\
\hline South-Idjwi & BK19 & Tholeiite & $9.56 \pm 0.48$ & 7 & Upper-Rusizi & 5 & Basanite & $5.9 \pm 0.4$ & \\
\hline Bishusha & TR24 & Mugearite & $9.2 \pm 1.0$ & 6 & Kahuzi & RTL180 & Ol-Tholeiite & $5.9 \pm 0.3$ & 5 \\
\hline East-Cyangugu & 14 & Ol-Tholeiite & $9.0 \pm 0.6$ & 5 & Mwenga & K157 & Ol-Basalt & $5.8 \pm 1.1$ & 5 \\
\hline Bitare & RW86 & Tholeiite & $8.97 \pm 0.45$ & 7 & Upper-Rusizi & 25 & Trachyte & $5.74 \pm 0.23$ & 5 \\
\hline Tongo & N378 & Basanite & $8.9 \pm 0.5$ & 3 & Upper-Rusizi & 23 & Trachyte & $5.74 \pm 0.09$ & 5 \\
\hline South-Idjwi & BK15 & Tholeiite & $8.76 \pm 0.44$ & 7 & Upper-Rusizi & 4 & Basanite & $5.7 \pm 0.4$ & \\
\hline W-Bukavu & 1 & Alk-Basalt & $8.5 \pm 0.5$ & 5 & Upper-Rusizi & 21 & Phonolite & $5.7 \pm 0.3$ & \\
\hline East-Cyangugu & 20 & Tholeiite & $8.4 \pm 0.3$ & 5 & North-Mushaka & 7 & Hawaiite & $5.65 \pm 0.23$ & 5 \\
\hline Upper-Rusizi & & Ol-Basalt & $8.3 \pm 1.1$ & 1 & Bugarama & 15 & Hawaiite & $5.6 \pm 0.3$ & \\
\hline Kahuzi & AK256 & Alk-Basalt & $8.2 \pm 0.4$ & 6 & Upper-Rusizi & 24 & Trachyte & $5.05 \pm 0.4$ & 5 \\
\hline Kahuzi & MM2 & Alk-Basalt & $8.19 \pm 0.40$ & 7 & Mwenga & K40 & Alk-Basalt & $4.2 \pm 1.1$ & 6 \\
\hline Upper-Rusizi & RW90 & Ol-basalt & $8.10 \pm 0.40$ & 7 & South-Idjwi & I-84-30 & Ol-Basalt & $4.1 \pm 1$ & \\
\hline Upper-Rusizi & 26 & Tholeiite & $8.0 \pm 1.0$ & 5 & NW-Bukavu & 6 & Basanite & $4.06 \pm 0.21$ & \\
\hline Mushaka & 3 & Basanite & $7.99 \pm 0.24$ & 5 & Mwenga & K58 & Basanite & $2.6 \pm 1.6$ & 6 \\
\hline Bugarama & RW83 & Basanite & $7.75 \pm 0.39$ & 7 & Mikeno & & Trachyte & $2.6 \pm 0.4$ & \\
\hline South-Idjwi & BK36 & Tholeiite & $7.73 \pm 0.30$ & 7 & Tshibinda & TB4 & Basanite & $1.9 \pm 0.1$ & \\
\hline Upper-Rusizi & RW89 & Alk-Basalt & $7.68 \pm 0.38$ & 7 & Tshibinda & MM1 & Basanite & $1.7 \pm 0.2$ & \\
\hline Burundi & 28 & Tholeiite & $7.6 \pm 1.4$ & 5 & Tshibinda & KT1 & Ol-Basalt & $1.6 \pm 0.3$ & \\
\hline
\end{tabular}


Fig. 1

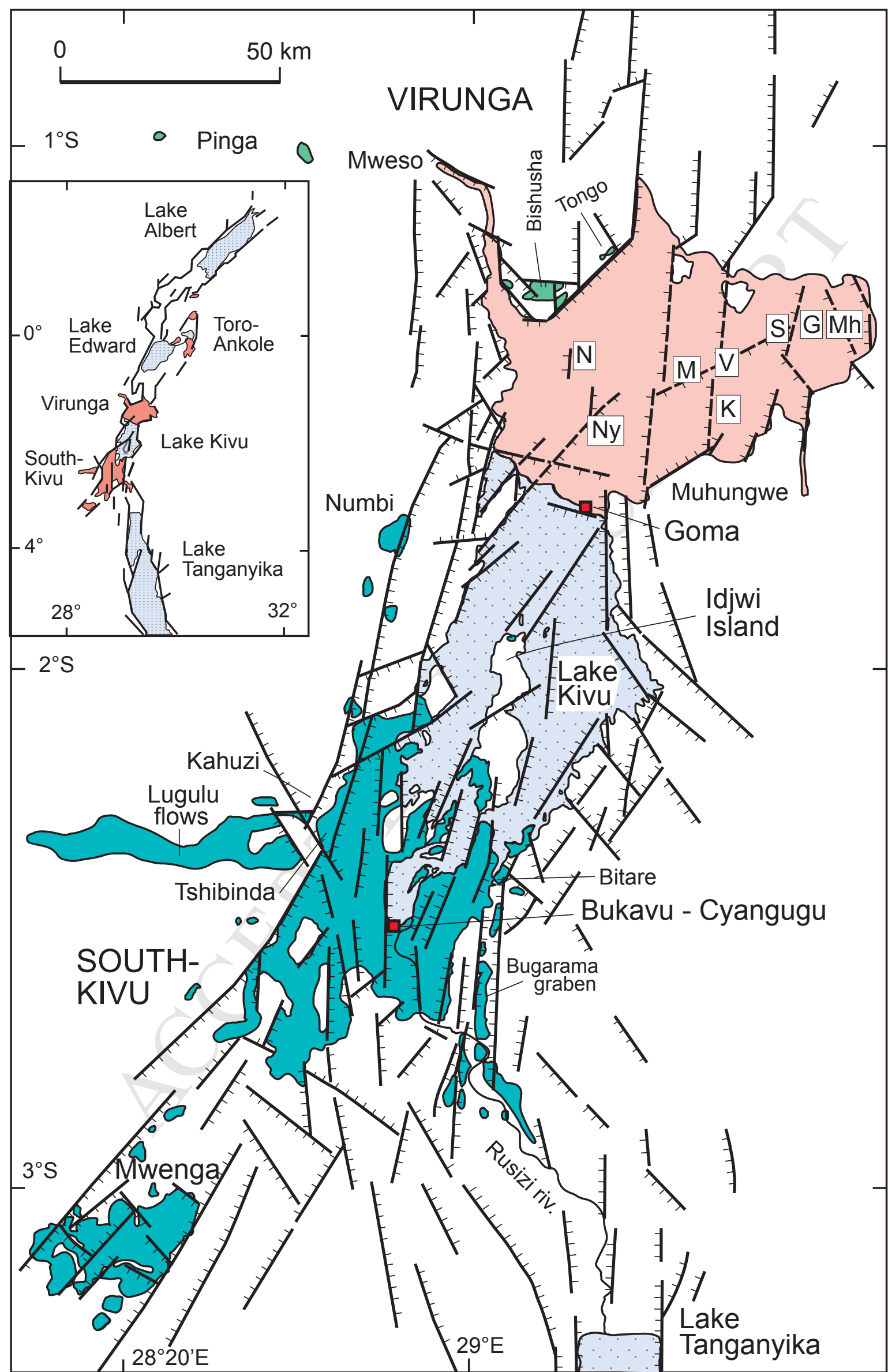


Fig. 2
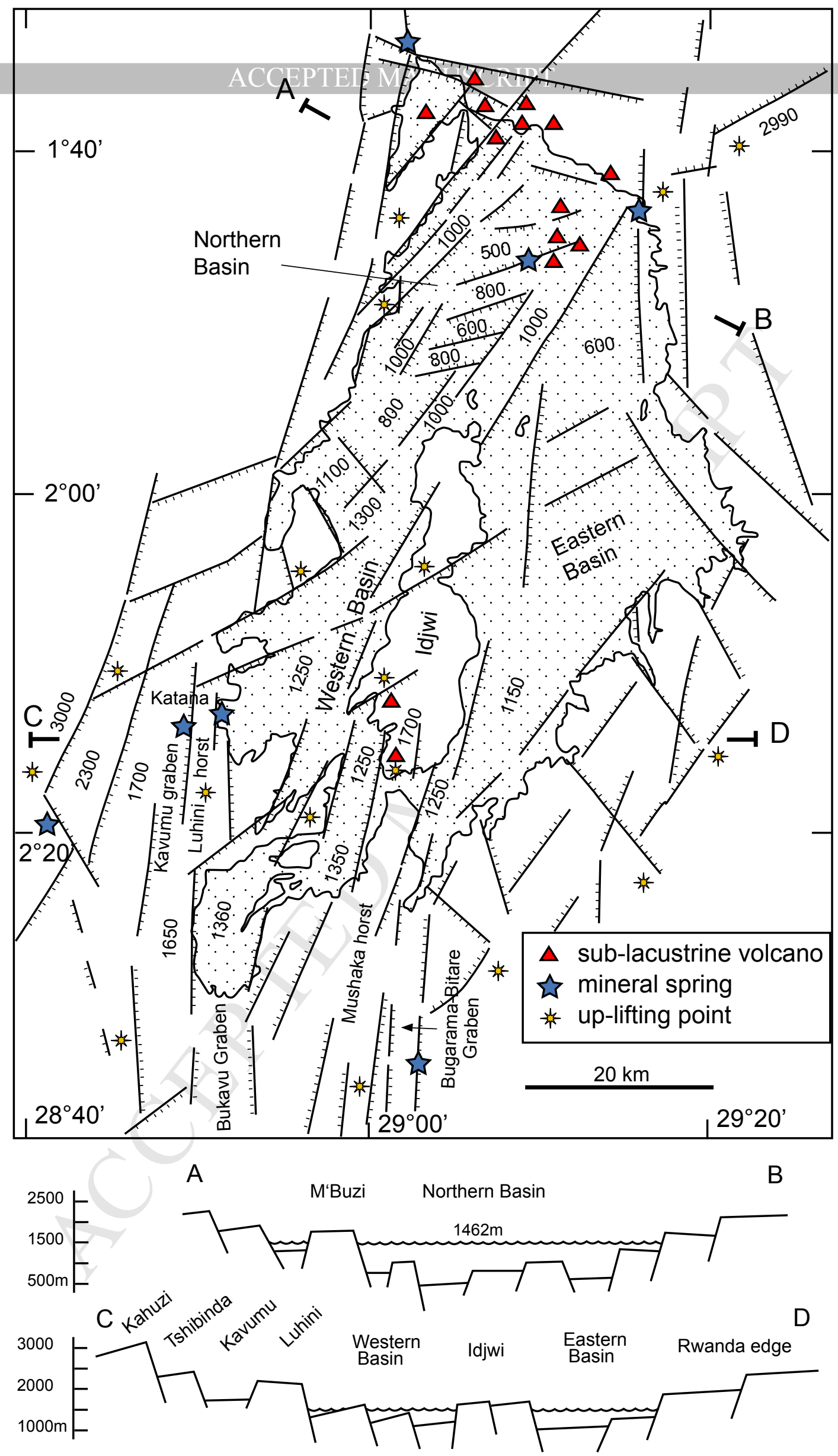
Fig. 3

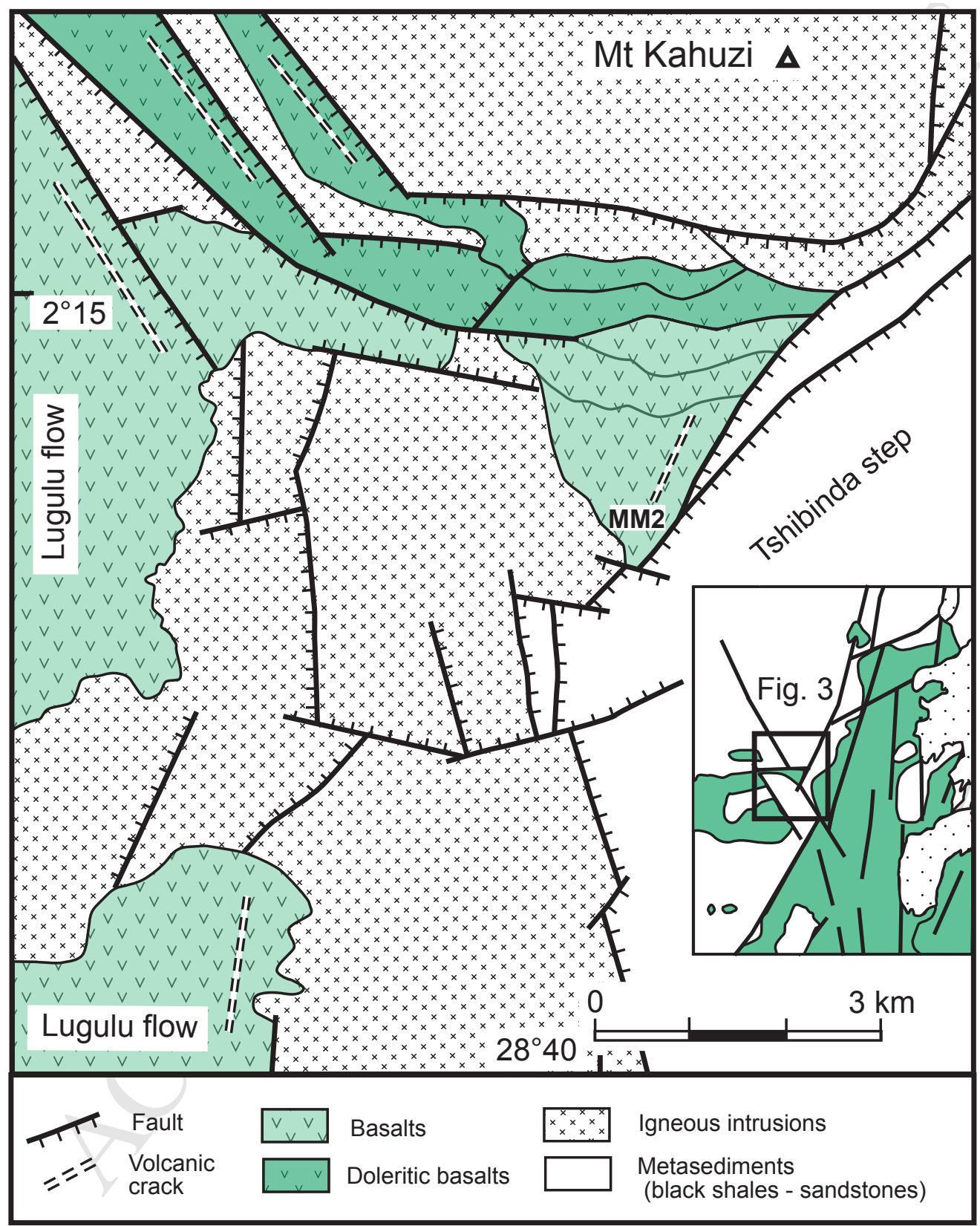


Fig. 4

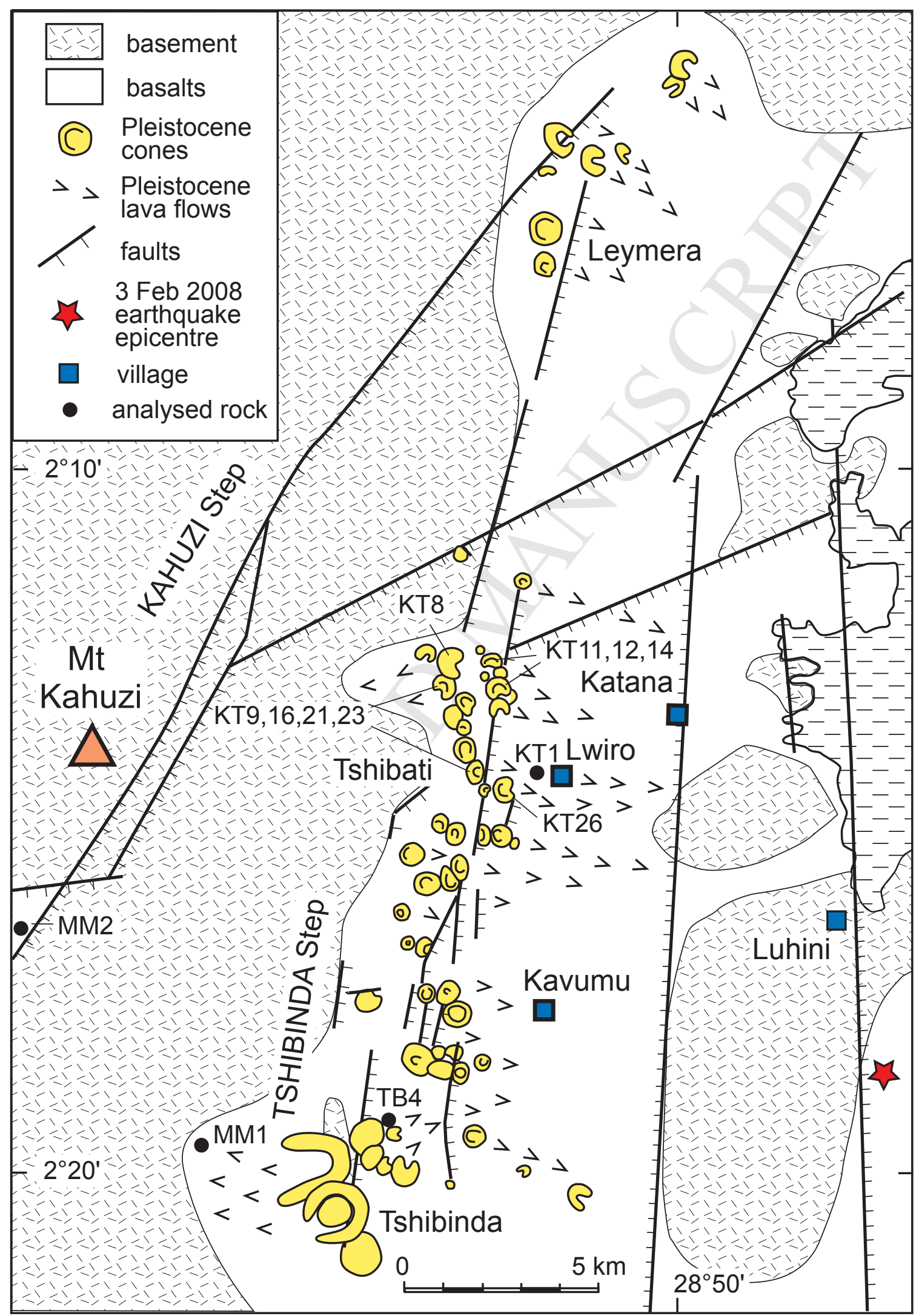




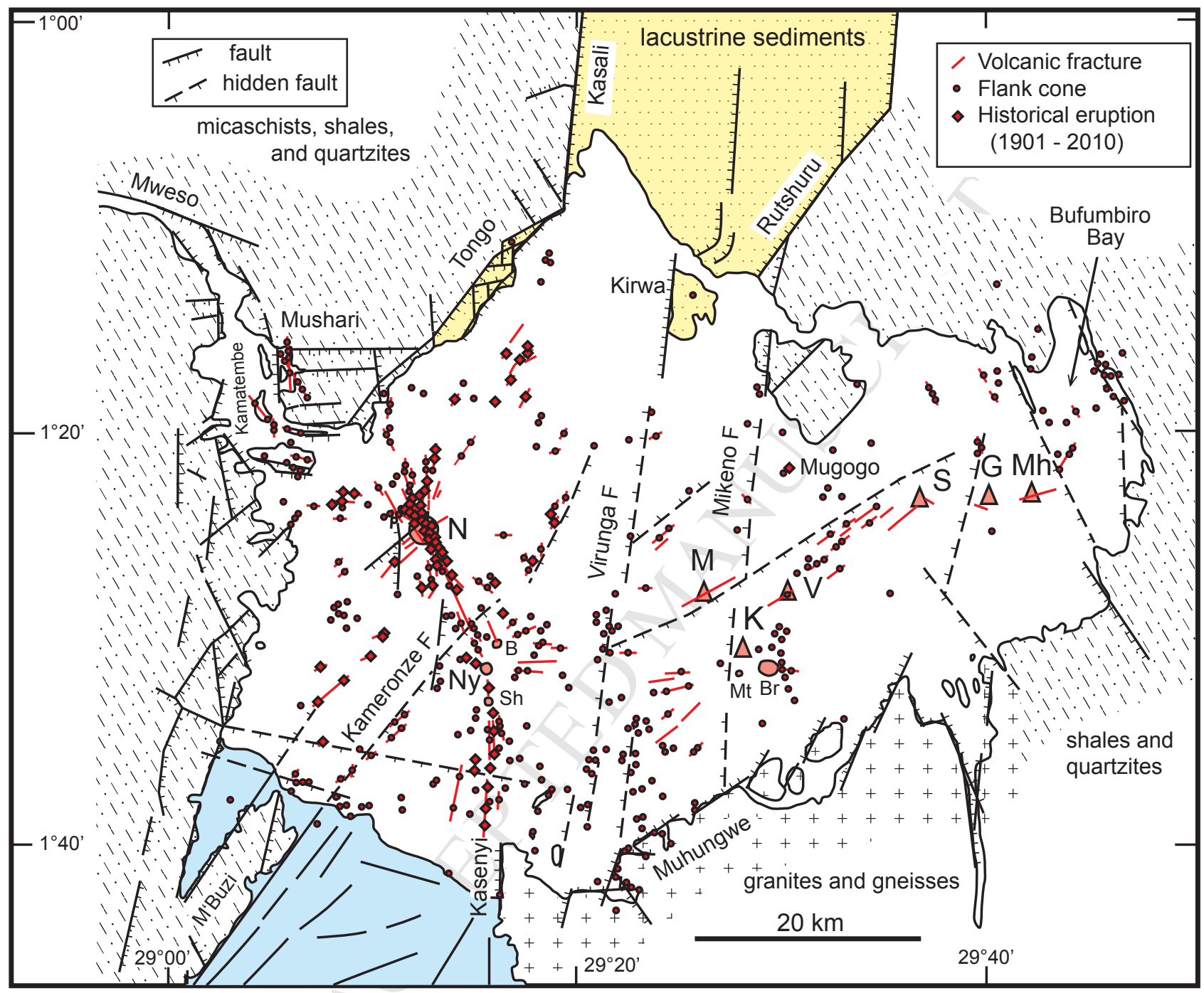


Fig. 6

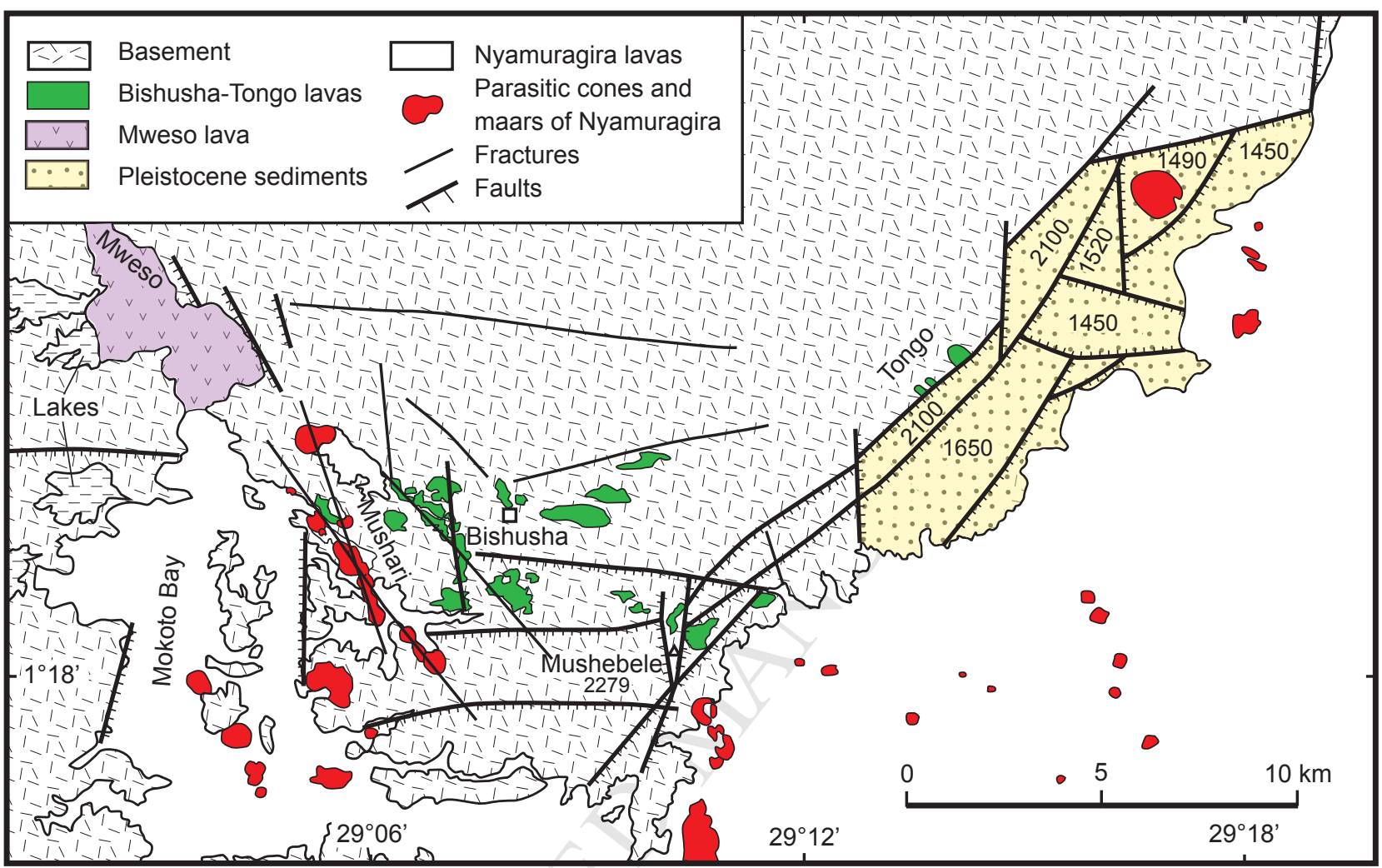


Fig. 7

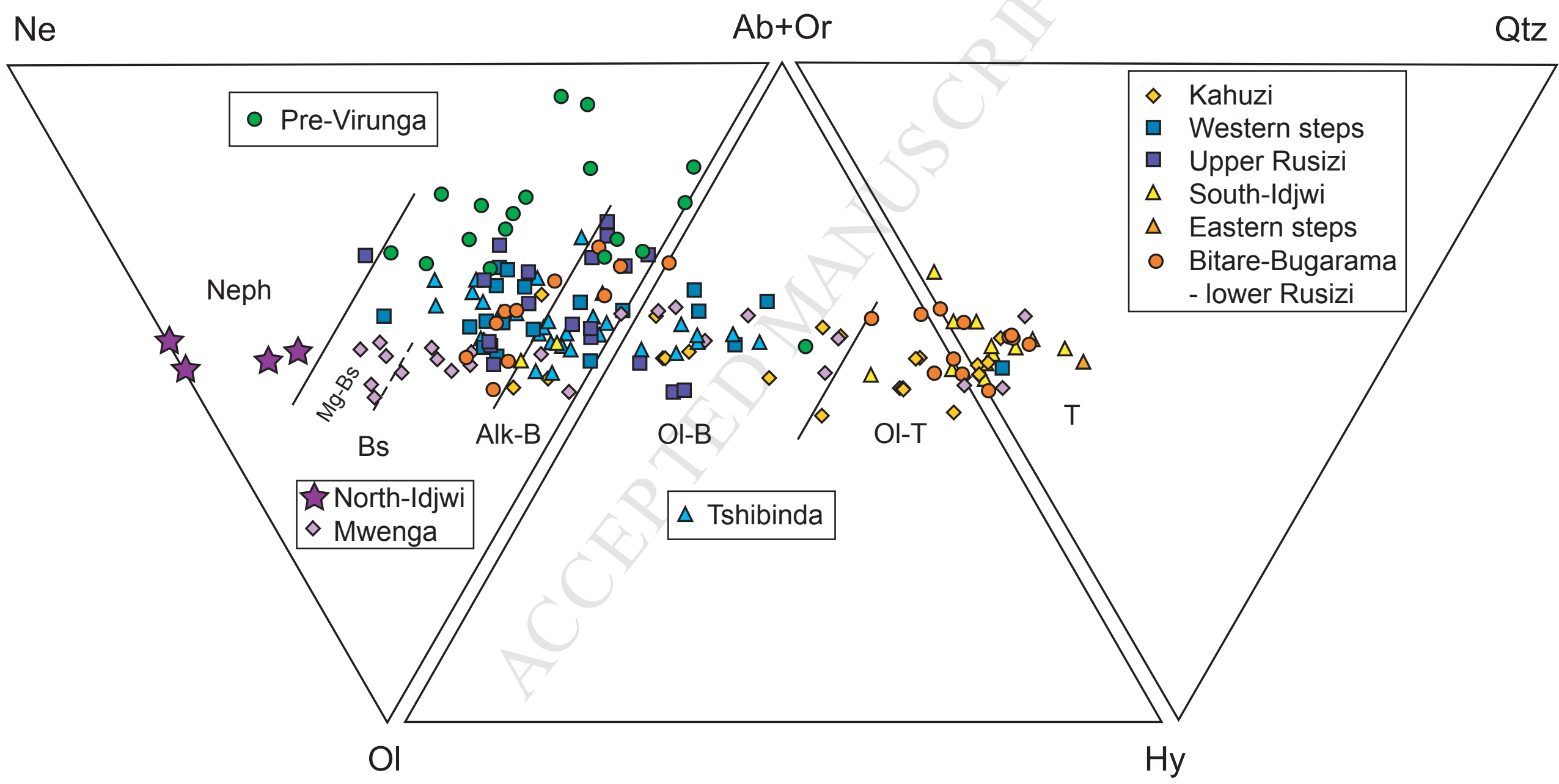


Fig. 8

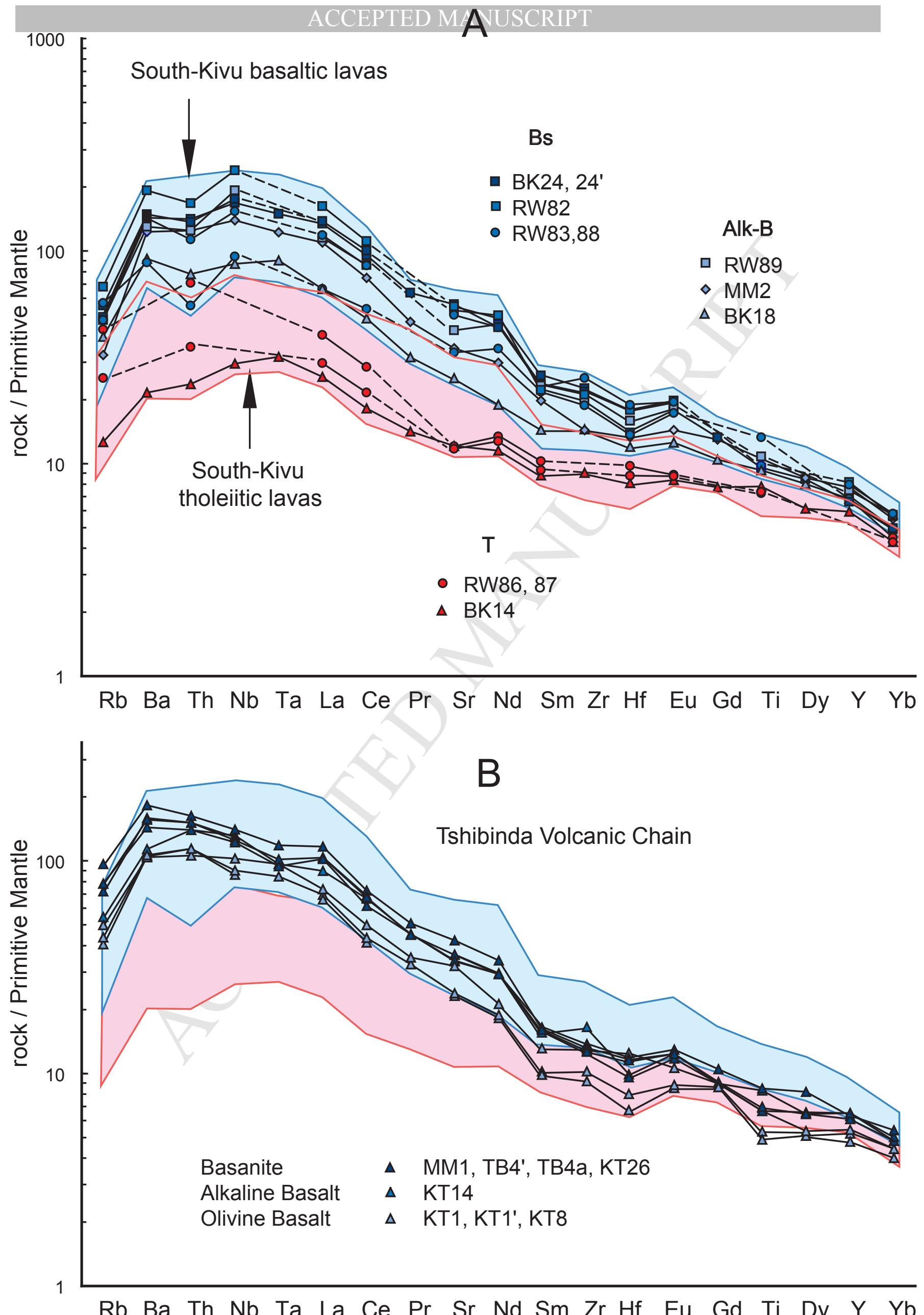


Fig. 9
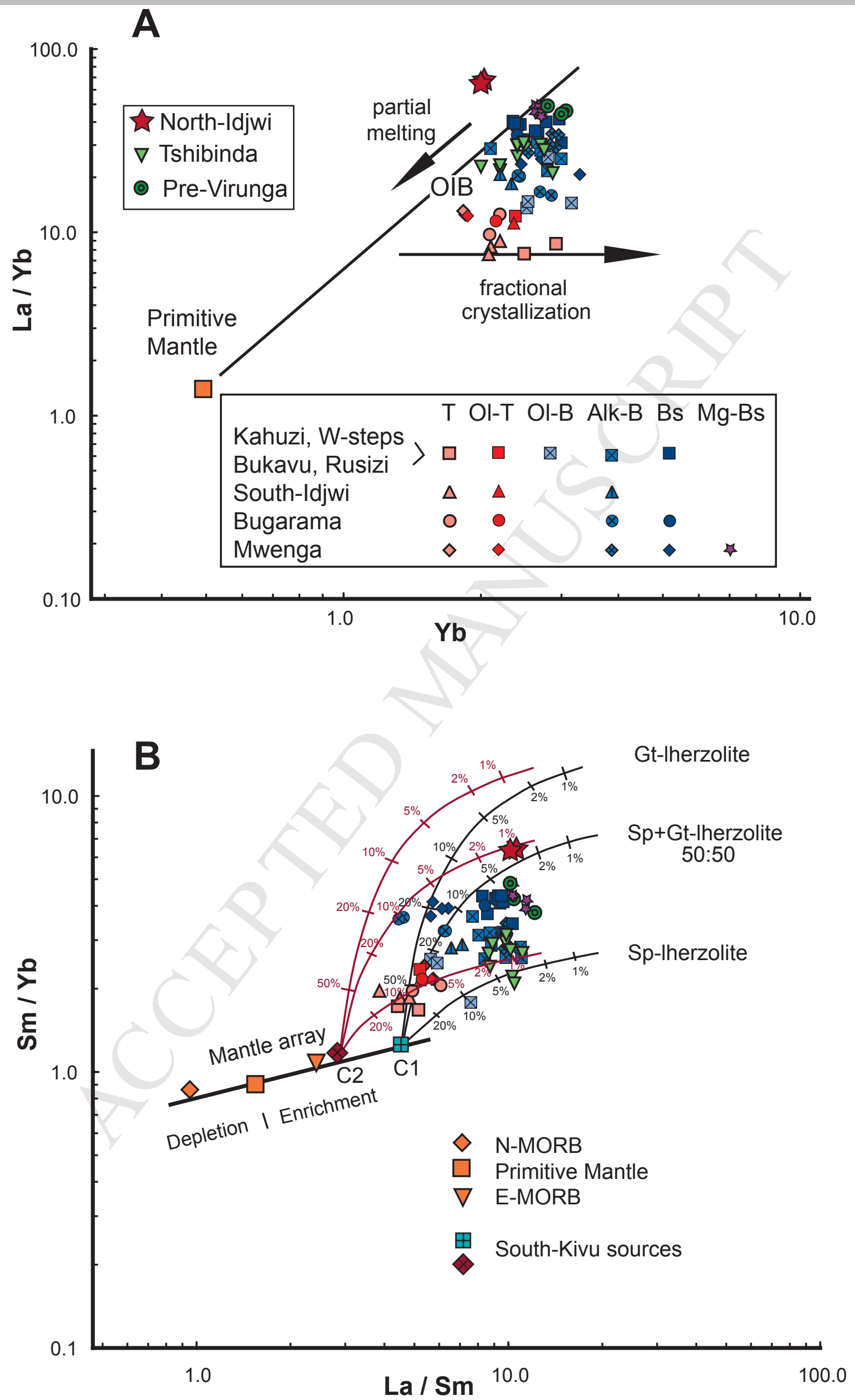
Fig. 10

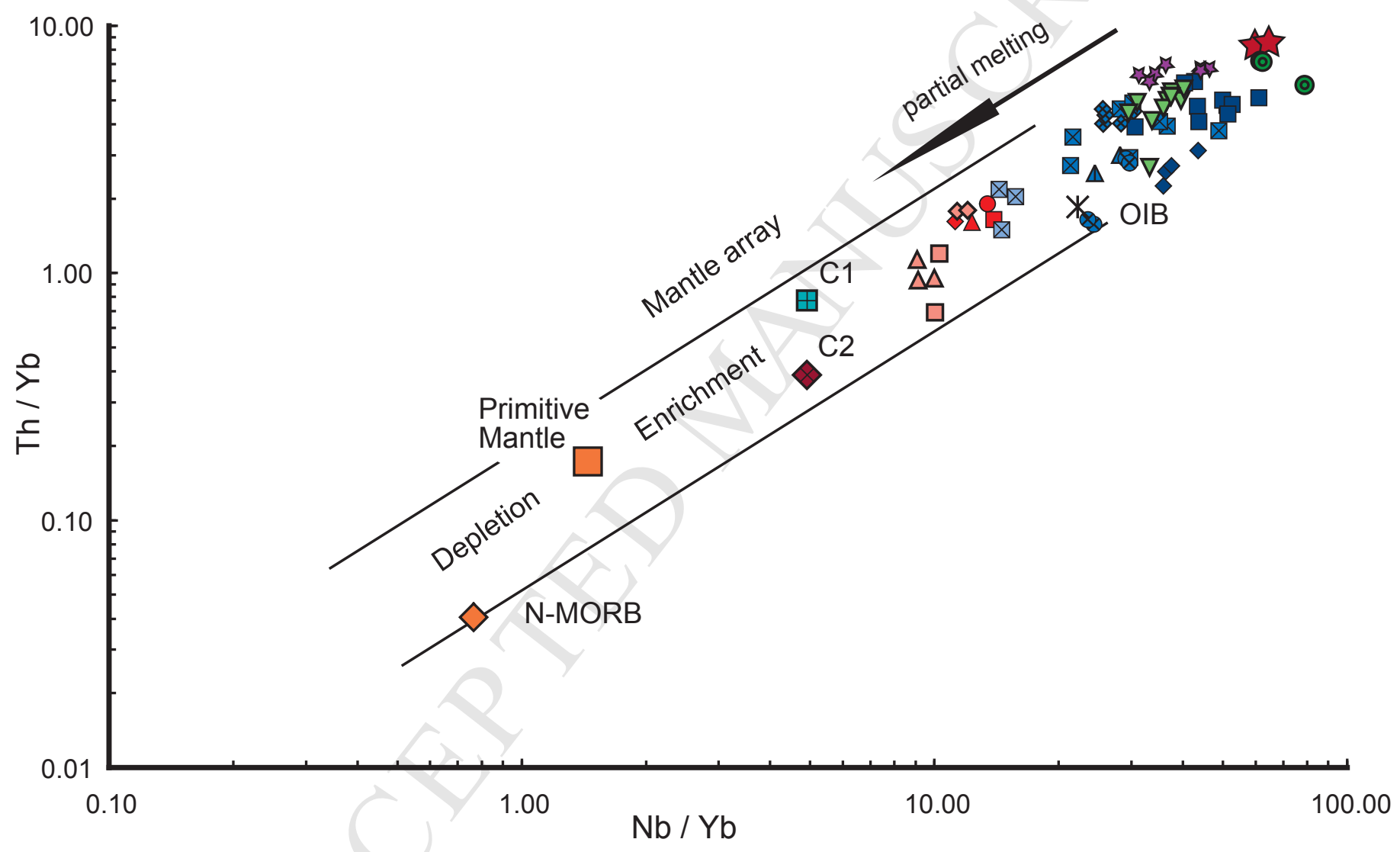


Fig. $11^{4}[\mathbf{A}$
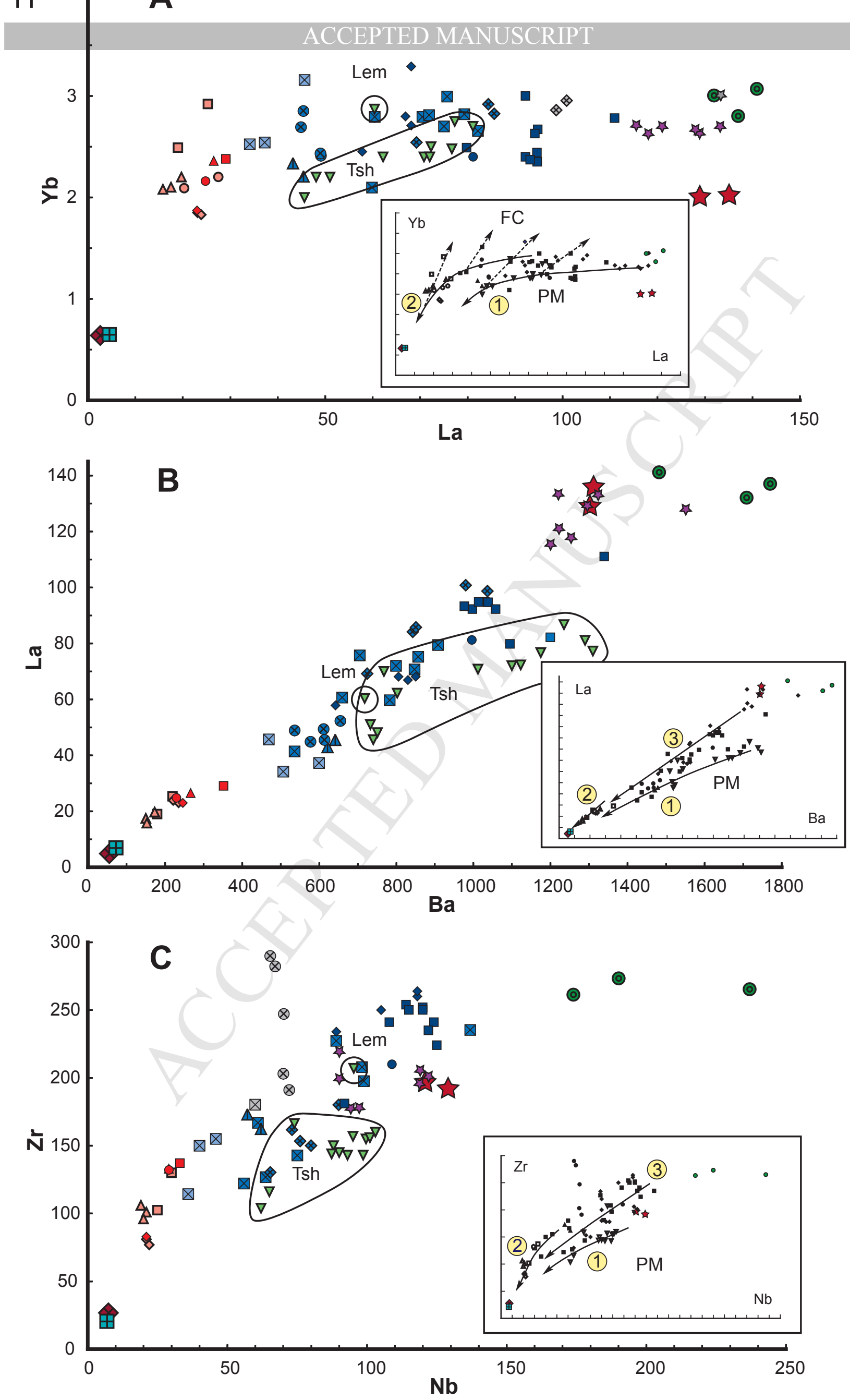
Fig. 12

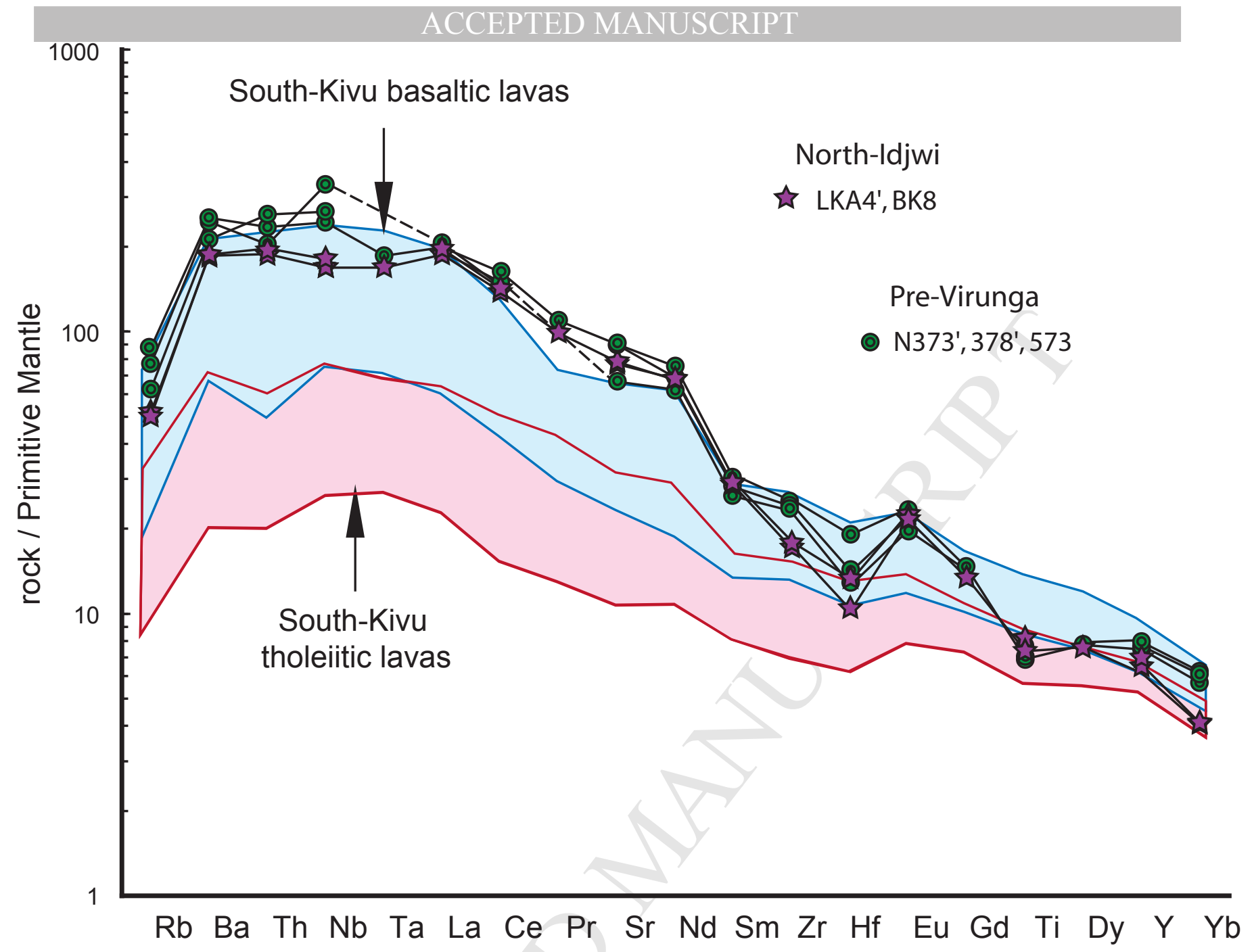


Fig. 13A, B
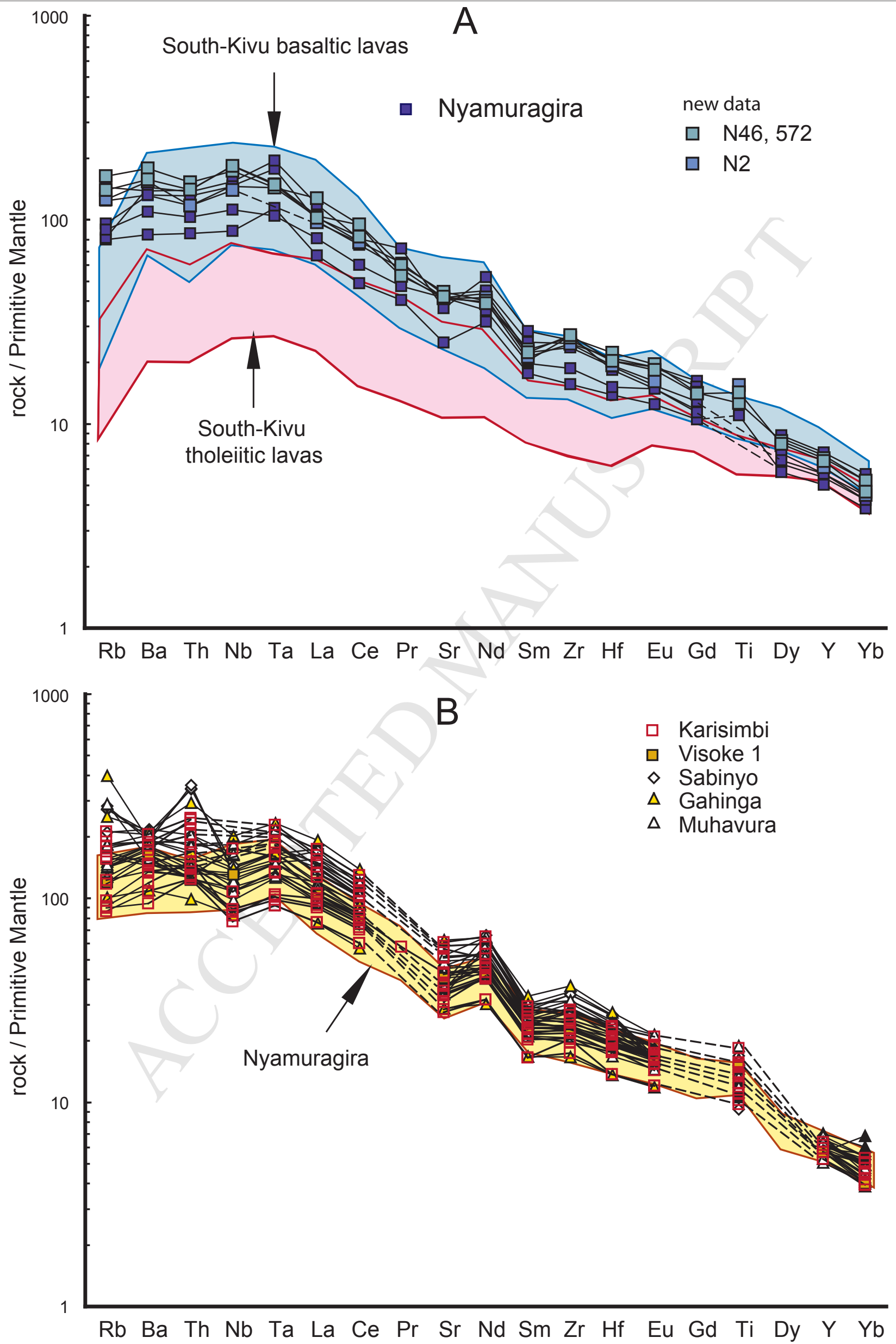
Fig. $13 C, D$
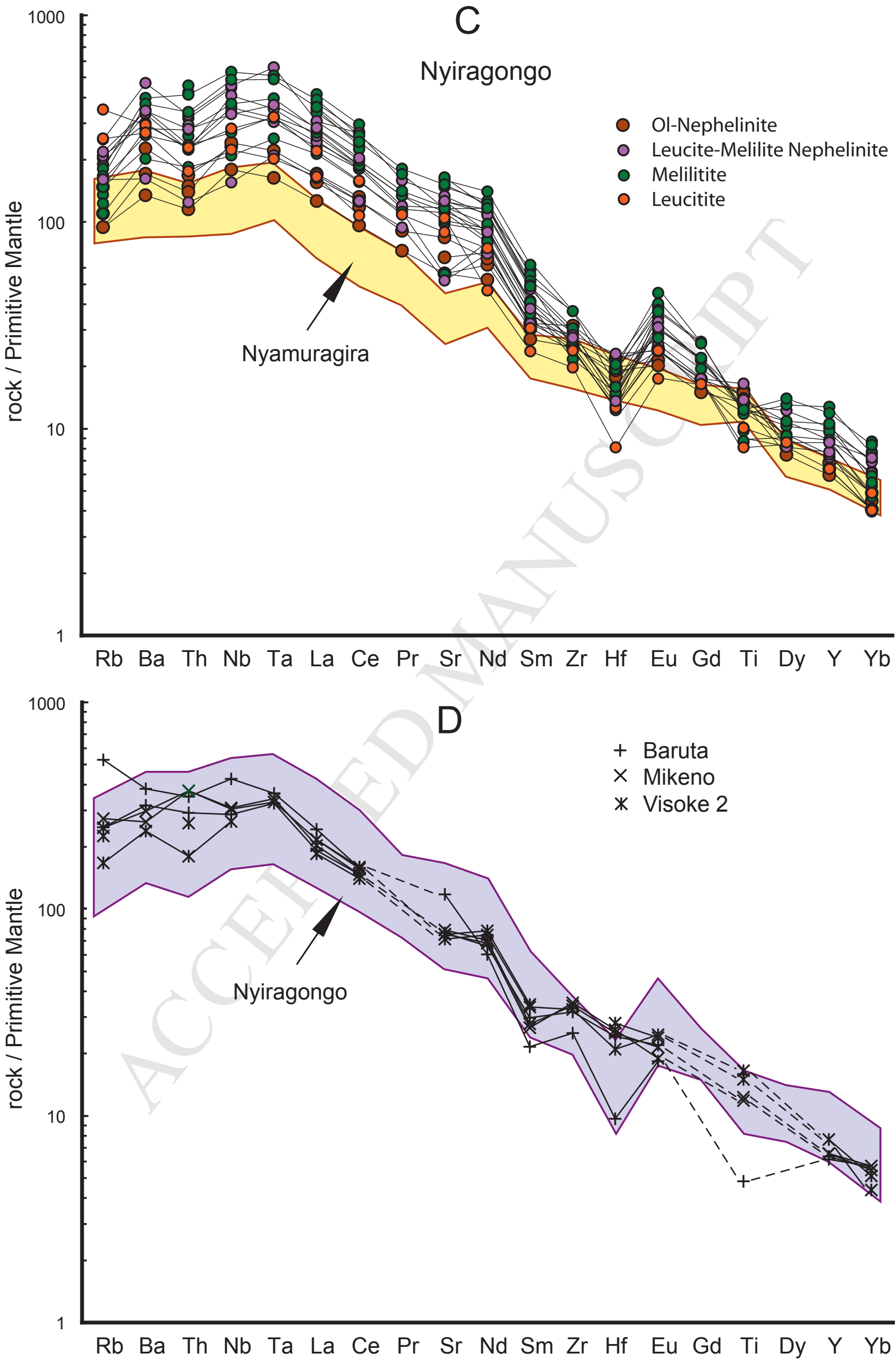


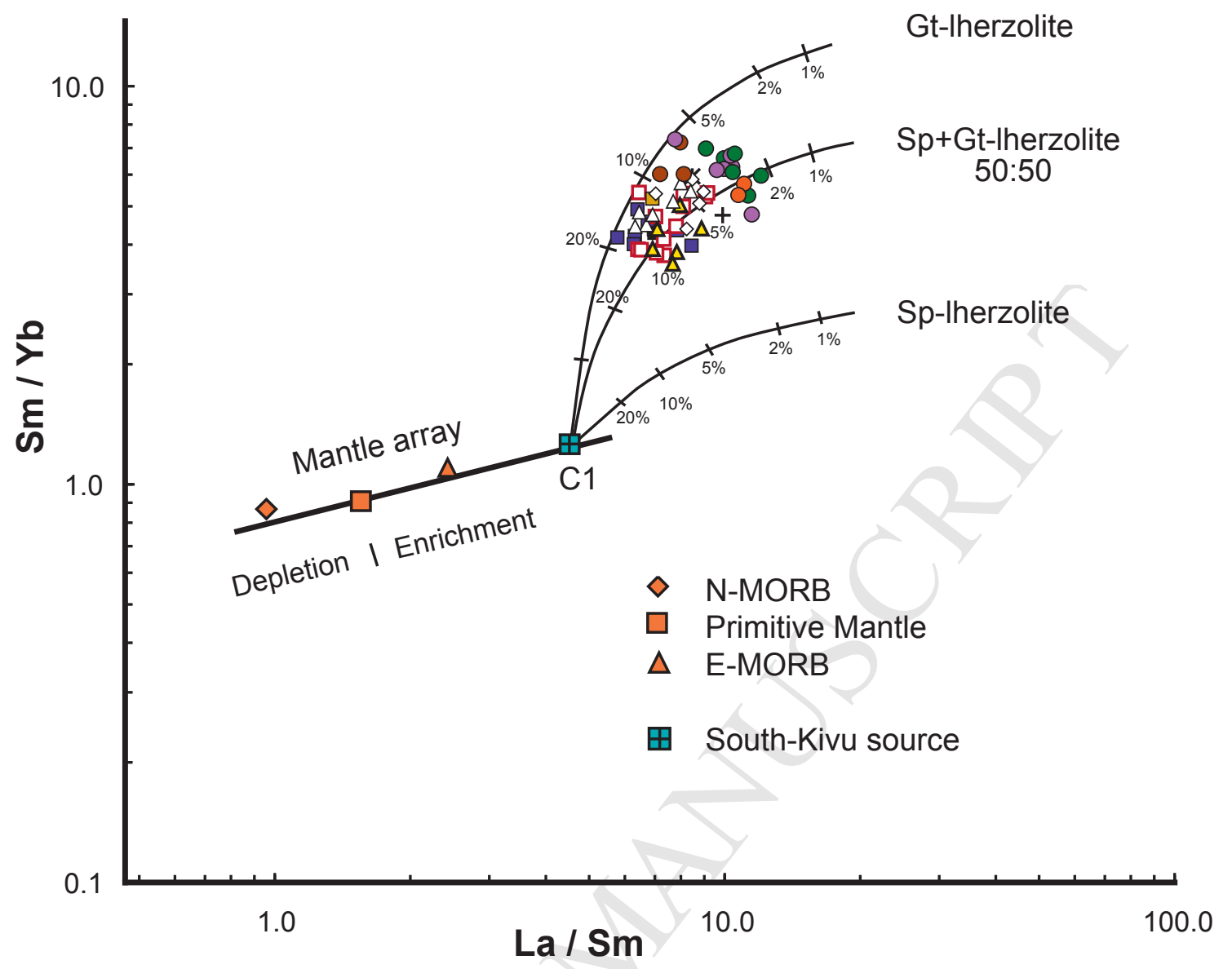


Fig. 15

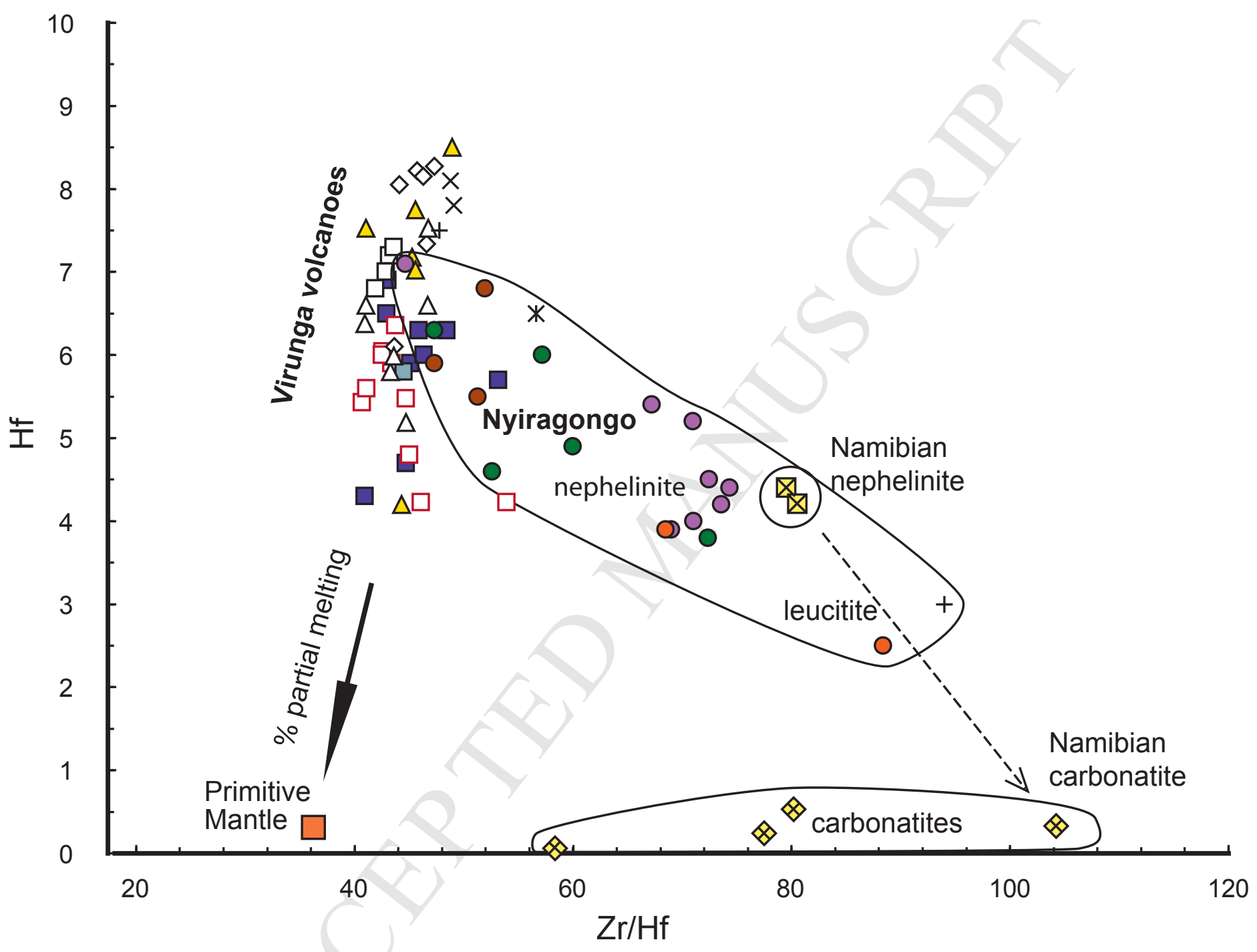


Fig. 16

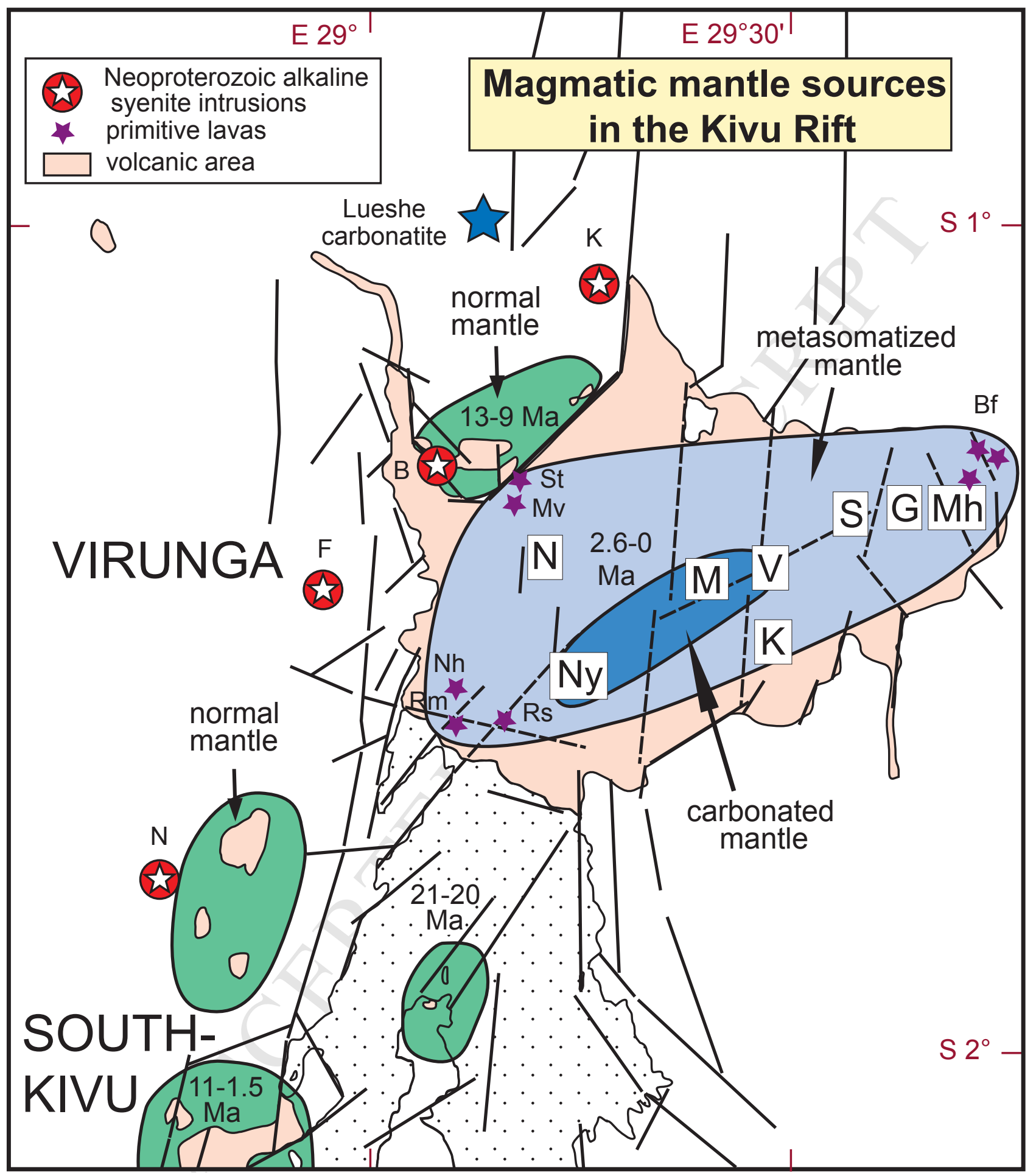


Fig. 17

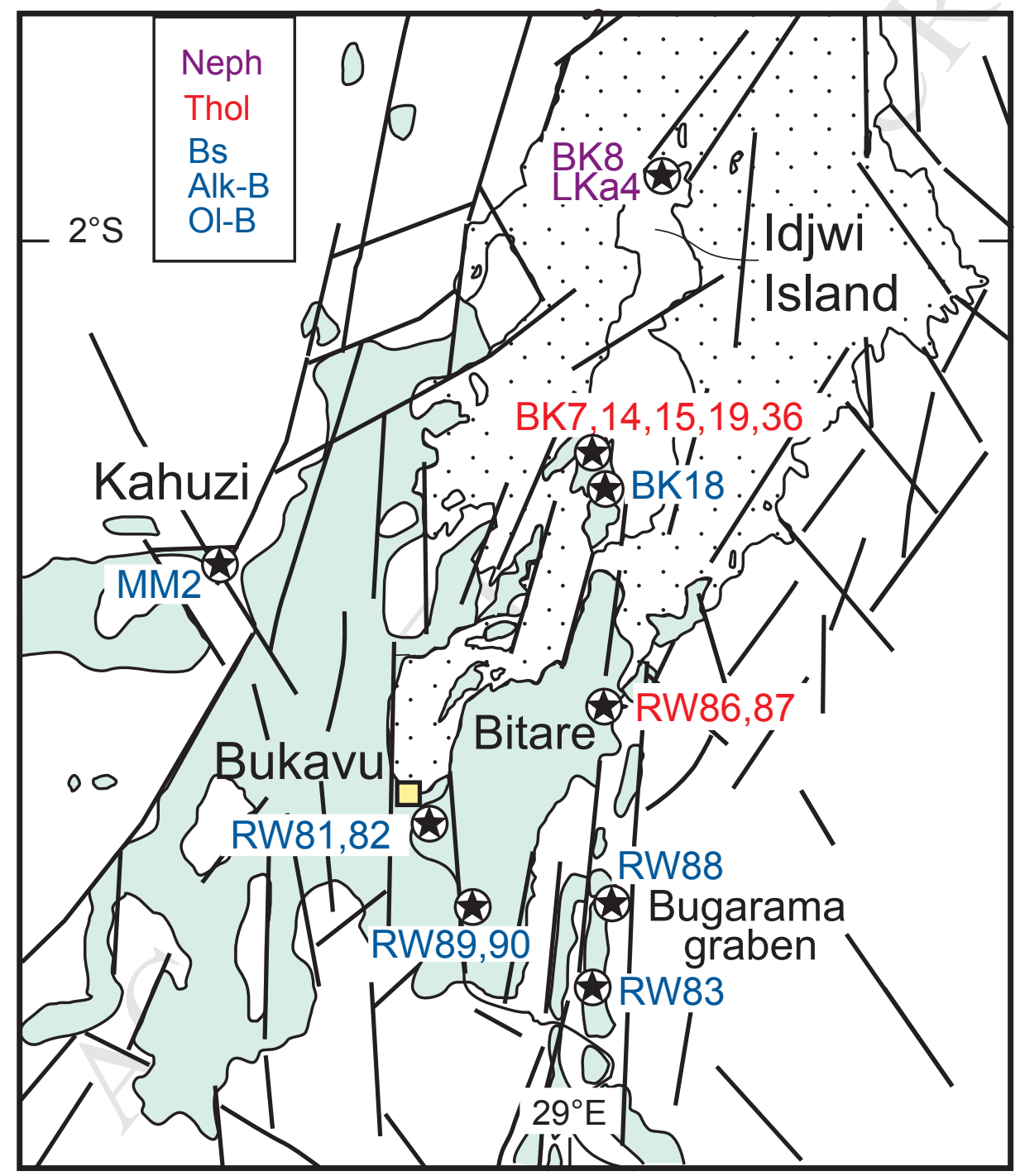


Fig. 18

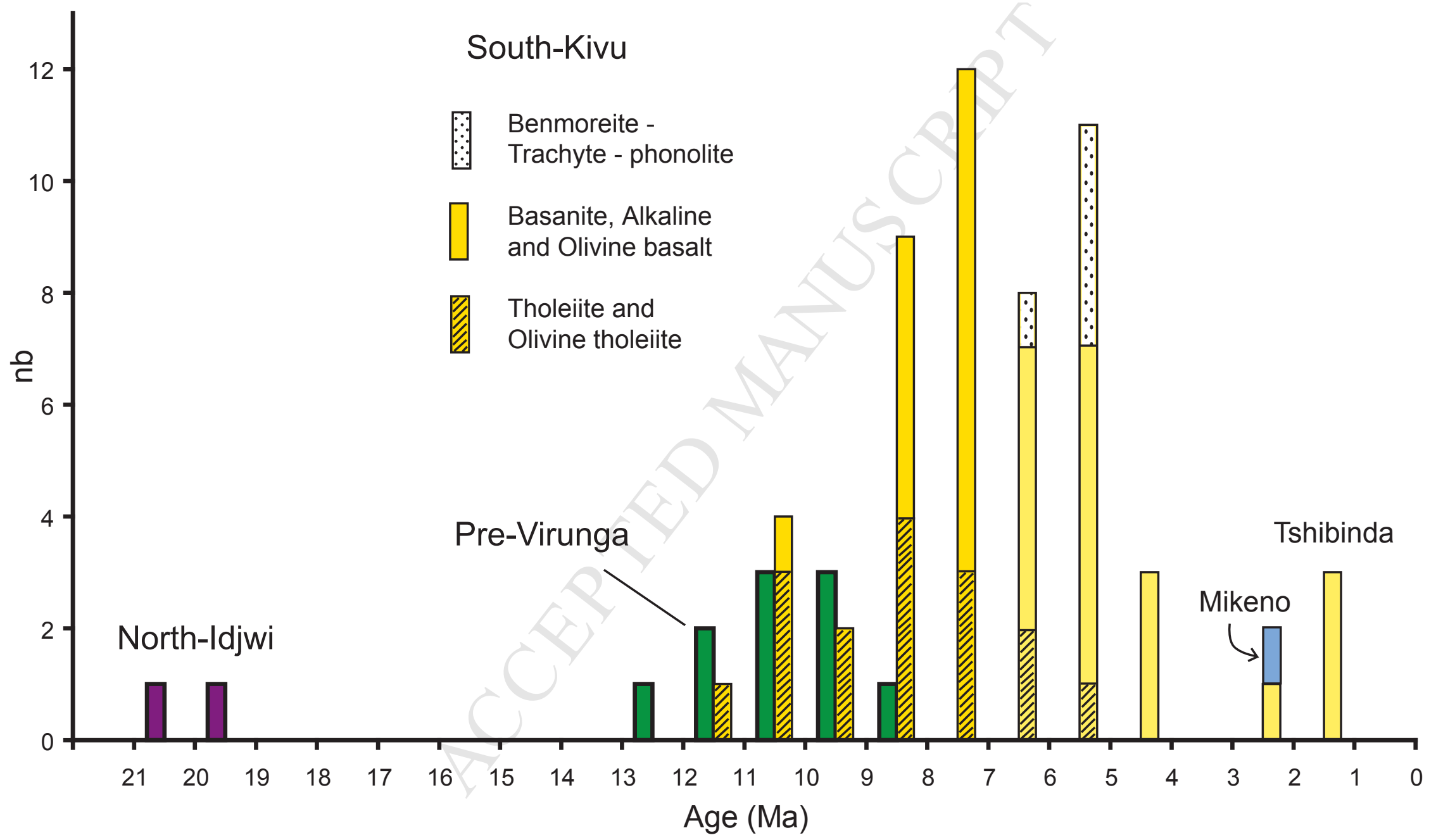



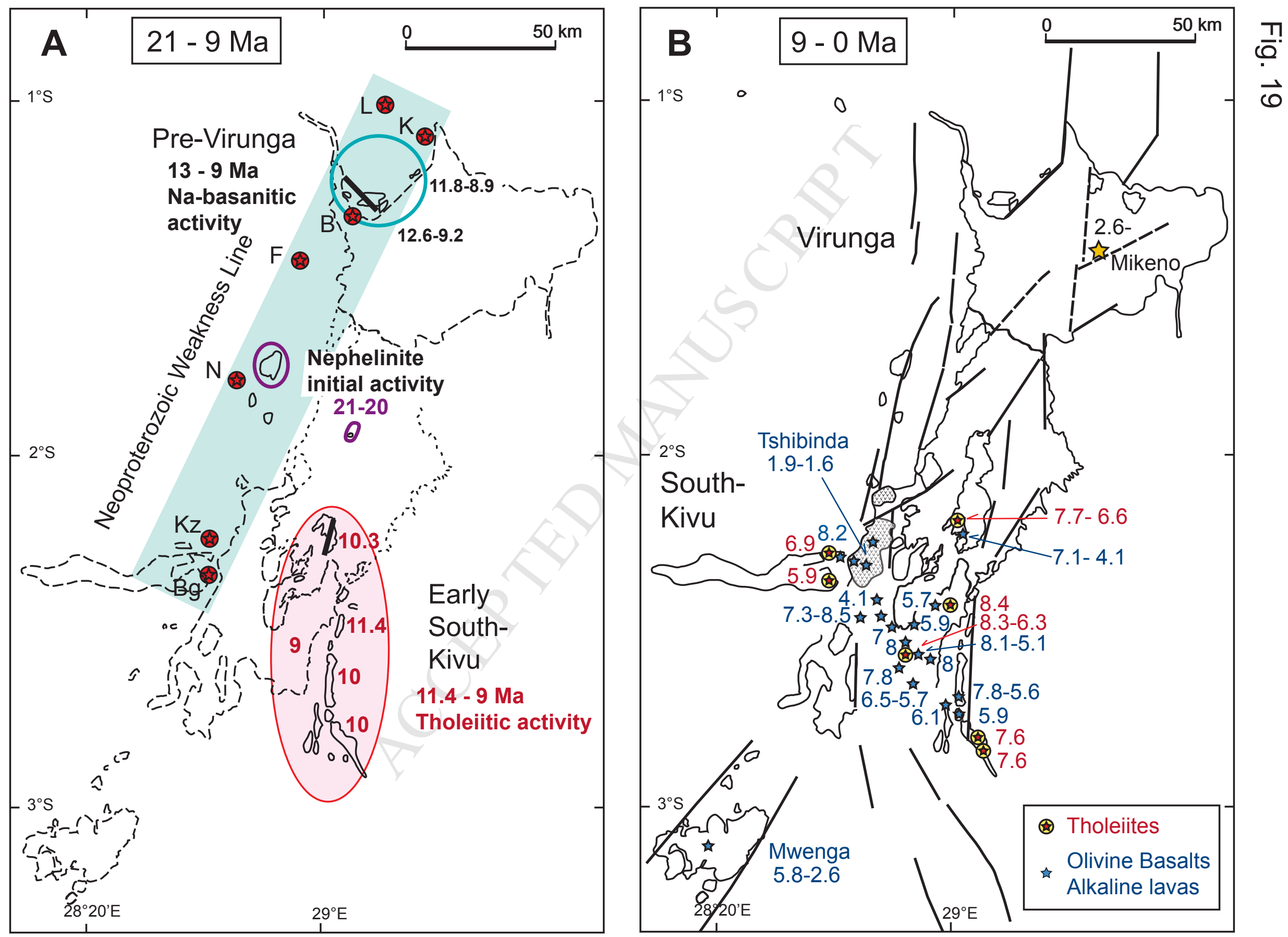


\section{Highlights}

The pre-rift doming stage of the Kivu rift (East African Rift system) is dated at 21 Ma by nephelinites.

Tholeiite lavas initiate the extensional stage between 11 and $9 \mathrm{Ma}$.

In the Pliocene, alkali basalts indicate decreasing of the extensional process and cooling of the mantle.

Quaternary renewal of the activity in the Virunga is linked to a tension gash with an ENEWSW extension. 